Prepared for the U.S. Department of Energy

under Contract DE-AC05-76RL01830

\title{
No-Impact Threshold Values for NRAP's Reduced Order Models
}

GV Last

CJ Murray

CF Brown
PD Jordan

M Sharma

February 2013

Pacific Northwest

NATIONAL LABORATORY

Proudly Operated by Battelle Since 1965 


\title{
DISCLAIMER
}

This report was prepared as an account of work sponsored by an agency of the United States Government. Neither the United States Government nor any agency thereof, nor Battelle Memorial Institute, nor any of their employees, makes any warranty, express or implied, or assumes any legal liability or responsibility for the accuracy, completeness, or usefulness of any information, apparatus, product, or process disclosed, or represents that its use would not infringe privately owned rights. Reference herein to any specific commercial product. process, or senvice by trade name, trademark, manufacturer, or otherwise does not necessarily constitute or imply its endorsement, recommendation, or favoring by the United States Government or any agency thereof, or Battelle Memorial Institute. The views and opinions of authors expressed herein do not necessarily state or reflect those of the United States Government or any agency thereof.

\author{
PACIFIC NORTHWEST NATIONAL LABORATORY \\ operated by \\ BATTELLE \\ for the \\ UNITED STATES DEPARTMENT OF ENERGY \\ under Contract DE-AC05-76RL01830
}

Printed in the United States of America
Available to DOE and DOE contractors from the Office of Scientific and Technical Information.
P.O. Box 62, Oak Ridge, TN 37831-0062;
ph: (865) 576-8401
fax: $(865) 576-5728$
email: reports a adonis.osti.gov
Available to the public from the National Technical Information Service 5301 Shawnee Rd,, Alexandria, VA 22312 ph: (800) 553-NTIS (6847) email: erdersaintis.gov <htrp://www.ntis.gov/about/form.aspx> Online ordering: http://www.ntis.gov




\title{
No-Impact Threshold Values for NRAP's Reduced Order Models
}

\author{
GV Last \\ PD Jordan ${ }^{1}$ \\ CJ Murray \\ M Sharma $^{2}$
}

CF Brown

February 2013

Prepared for

the U.S. Department of Energy

under Contract DE-AC05-76RL01830

Pacific Northwest National Laboratory

Richland, Washington 99352

\footnotetext{
${ }^{1}$ Lawrence Berkeley National Laboratory, Berkeley, California.

${ }^{2}$ West Virginia University, National Energy Technology Laboratory, Morgantown, West Virginia.
} 



\section{Summary}

The purpose of this study was to examine methodologies for establishing baseline data sets and statistical protocols for determining statistically significant changes between background concentrations and predicted concentrations that would be used to represent a contamination plume in the Gen II models being developed by the National Risk Assessment Partnership's Groundwater Protection team.

The initial effort examined selected portions of two aquifer systems: the urban shallow-unconfined aquifer system of the Edwards-Trinity Aquifer System (being used to develop the reduced order model for carbon-rock aquifers), and a portion of the High Plains Aquifer (an unconsolidated and semiconsolidated sand and gravel aquifer being used to develop the reduced order model for sandstone aquifers). No-impact threshold values were determined for cadmium, lead, arsenic, $\mathrm{pH}$, and total dissolved solids that could be used to identify potential areas of contamination predicted by numerical models of carbon sequestration storage reservoirs. No-impact threshold values were later determined for chromium specifically to support the reduced order model being developed by Lawrence Livermore National Laboratory for the High Plains Aquifer. These threshold values are based on an interwell approach for determining background groundwater concentrations as recommended in the U.S. Environmental Protection Agency's Unified Guidance for Statistical Analysis of Groundwater Monitoring Data at RCRA Facilities (EPA 2009).

The resulting no-impact threshold values can be used to inform a "no change" scenario with respect to groundwater impacts, rather than use a maximum concentration limit or secondary drinking water standard that in some cases could be significantly higher than existing concentrations in the aquifer. These no-impact threshold values are intended for use in helping to predict areas of potential impact. They are not intended for use as alternate regulatory limits.

Development of "generic" no-impact threshold values that could be used for a number of locations appears unlikely. Instead the threshold values must be based on site-specific groundwater quality data. However, the scarcity of existing data, proximity of the data to the target model domain, potential spatial heterogeneity, and temporal trends make development of "clean" statistically robust data sets and use of valid statistical assumptions challenging. In some cases the calculated no-impact threshold values may exceed regulatory standards. Other approaches such as the hybrid intrawell-interwell approach also examined in this study may provide other mechanisms for calculating no-impact threshold limits. 



\section{Acknowledgments}

This work was completed as part of the National Risk Assessment Partnership (NRAP) Project. Support for this project came from the U.S. Department of Energy's Office of Fossil Energy Crosscutting Research Program. The authors wish to acknowledge Robert Romanosky (National Energy Technology Laboratory Strategic Center for Coal) and Regis Conrad (U.S. Department of Energy's Office of Fossil Energy) for programmatic guidance, direction, and support.

NRAP funding was provided to Pacific Northwest National Laboratory under U.S. Department of Energy contract number DE-AC05-76RL01830. Additional funding was provided to Lawrence Berkeley National Laboratory under U.S. Department of Energy contract number DE-AC02-05CH11231.

The authors wish to thank Kirk Cantrell for his technical peer review, and Hope Matthews and Kathy Neiderhiser for editorial review and document production. 



\section{Acronyms and Abbreviations}

$\begin{array}{ll}\text { ANOVA } & \text { analysis of variance } \\ \mathrm{CO}_{2} & \text { carbon dioxide } \\ \text { DOE } & \text { U.S. Department of Energy } \\ \text { EPA } & \text { U.S. Environmental Protection Agency } \\ \text { Gen II } & \text { Generation II (model) } \\ \text { GWPS } & \text { groundwater protection standard } \\ \text { KGS } & \text { Kansas Geological Survey } \\ \text { MCL } & \text { maximum contaminant level } \\ \text { NAWQA } & \text { National Water Quality Assessment } \\ \text { NRAP } & \text { National Risk Assessment Partnership } \\ \text { NWIS } & \text { National Water Information System } \\ \text { RCRA } & \text { Resource Conservation and Recovery Act of 1976 } \\ \text { ROM } & \text { Reduced Order Model } \\ \text { TDS } & \text { total dissolved solids } \\ \text { USDW } & \text { underground sources of drinking water } \\ \text { USGS } & \text { U.S. Geological Survey } \\ \text { WIMAS } & \text { Water Information Management System }\end{array}$





\section{Contents}

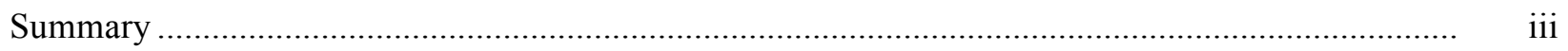

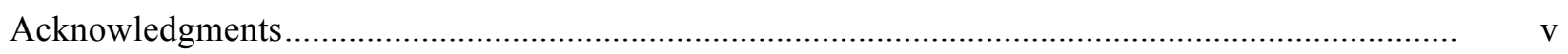

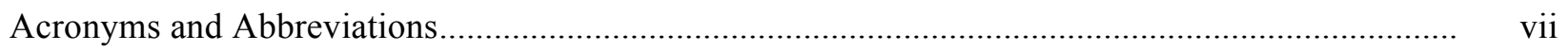

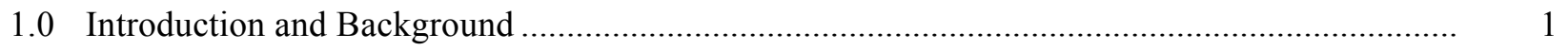

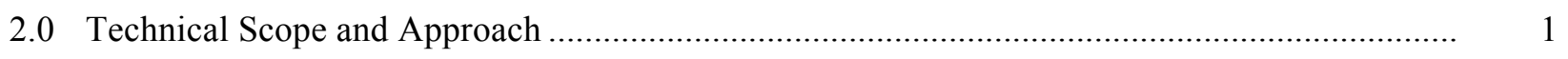

3.0 No-Impact Threshold Values.................................................................................... 2

3.1 No-Impact Threshold Values for the Edwards-Trinity Aquifer ....................................... 3

3.2 No-Impact Threshold Values for the High Plains Aquifer System.................................... 7

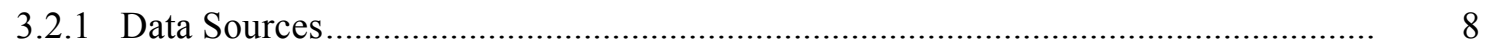

3.2.2 No-Impact Threshold Summary ….................................................................. 12

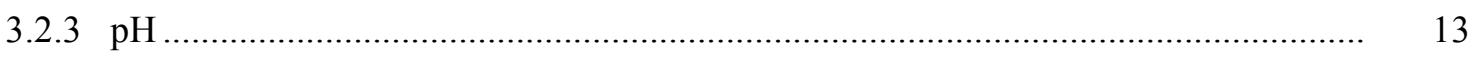

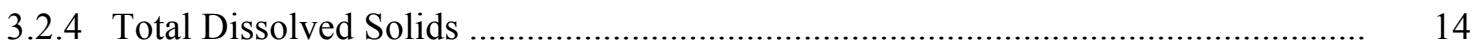

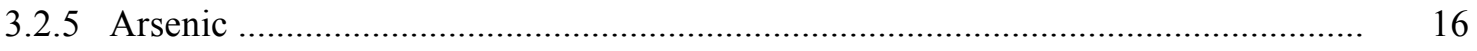

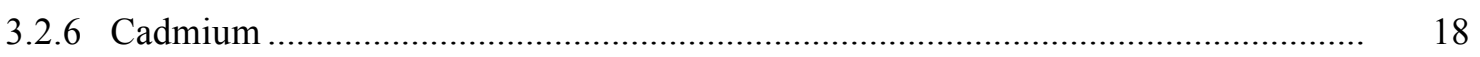

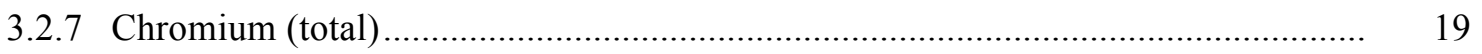

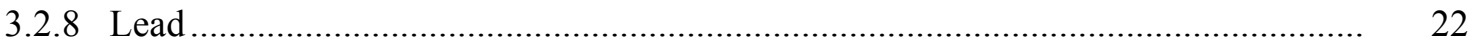

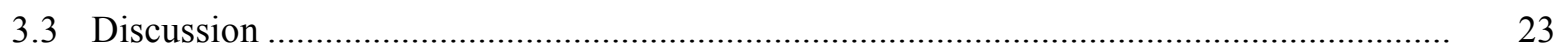

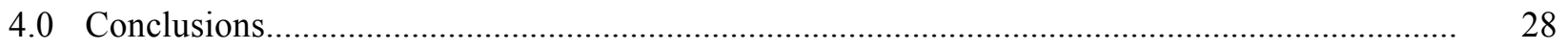

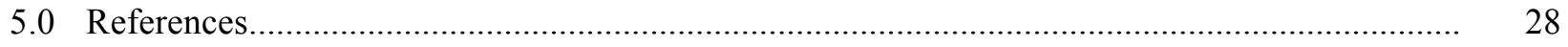

Appendix A - Data from the Shallow Urban Unconfined Edwards Aquifer Used for Analysis of Metals Concentrations ....................................................................................... A. A 1

Appendix B - Data from the Shallow Urban Unconfined Edwards Aquifer Used for Analysis of pH and TDS Concentrations.............................................................................. B. 1

Appendix C - Select National Water Quality Assessment Central High Plains Aquifer Data ........... C. C.1 


\section{Figures}

1 Location of shallow/urban unconfined wells for the Edwards Aquifer ..................................... 3

2 Histogram of arsenic concentrations for post-2000 samples from shallow/urban

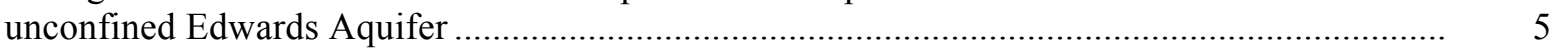

3 Histogram of $\mathrm{pH}$ values for all samples from shallow/urban unconfined Edwards Aquifer........ 5

4 Histogram of TDS concentrations for all samples from shallow/urban unconfined

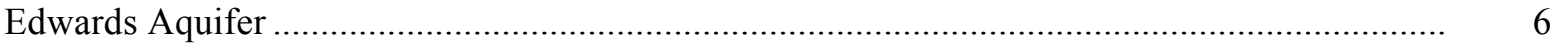

$5 \quad$ High Plains Aquifer and groundwater model location ......................................................... 8

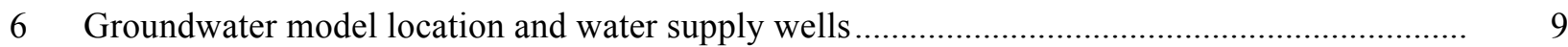

7 Resampled major aquifer study well $\mathrm{pH}$ in 2010 superimposed on contours resulting from kriging with a spherical variogram

8 Irrigated agriculture study well $\mathrm{pH}$ in 2000 superimposed on contours resulting from kriging with a spherical variogram

9 Results for $\mathrm{pH}$ in 2010 from resampled major aquifer study wells with data selected for threshold calculation indicated in blue ....

10 Histogram of selected $\mathrm{pH}$ in 2010 from major aquifer study wells.....

11 Results for TDS in 2010 from resampled major aquifer study wells superimposed on contours resulting from kriging with a spherical variogram

12 Histogram of select $2010 \log$ TDS from major aquifer study wells

13 Results for arsenic in 1999 from major aquifer study wells superimposed on contours resulting from kriging with a spherical variogram

14 Results for arsenic in 2010 from resampled major aquifer study wells superimposed on contours resulting from kriging 1999 concentrations with a spherical variogram .....

15 Histogram of select $2010 \log$ arsenic concentrations from major aquifer study wells

16 Results for cadmium in 2010 from resampled major aquifer study wells superimposed on contours resulting from kriging with a spherical variogram....

17 Histogram of select log cadmium concentrations in 2010 from major aquifer study wells .........

18 Results for chromium in 2010 from resampled major aquifer study wells.

19 Histogram of log chromium concentrations in 2010 from resampled major aquifer study wells

20 Results for lead in 2010 from resampled major aquifer study wells

21 Histogram of log lead concentrations in 2010 from resampled major aquifer study wells

22 The distribution of 2010 minus 1999 arsenic concentrations at the major aquifer study wells

23 Log-log plot of the 2010 against 1999 arsenic concentrations at the major aquifer study wells

24 Linear plot of the 2010 against 1999 arsenic concentrations at the major aquifer study wells

25 Linear plot of the 2010 against 1999 TDS at the major aquifer study wells ...

26 Linear plot of the 2010 against $1999 \mathrm{pH}$ at the major aquifer study wells 


\section{Tables}

1 Tolerance limits for concentrations in the urban portion of the unconfined Edwards

Aquifer.....

2 Initial values, tolerance limits, and regulatory standards for each variable ................................

3 No-impact thresholds for the High Plains Aquifer models based on sample data...................... 12 



\subsection{Introduction and Background}

The U.S. Department of Energy's (DOE) Office of Fossil Energy has established the National Risk Assessment Partnership (NRAP) Project. This is a multiyear project that harnesses the breadth of capabilities across the DOE national laboratory system to develop a defensible, science-based quantitative methodology for determining risk profiles at carbon dioxide $\left(\mathrm{CO}_{2}\right)$ storage sites. As part of this effort, scientists from Lawrence Berkeley National Laboratory (LBNL), Lawrence Livermore National Laboratory (LLNL), Los Alamos National Laboratory (LANL), Pacific Northwest National Laboratory (PNNL), and the National Energy Technology Laboratory (NETL) are developing models to evaluate the potential for aquifer impacts should $\mathrm{CO}_{2}$ or brine leak from deep subsurface storage reservoirs.

Modeling activities have been split across three successive years, with each year culminating with the generation of a more comprehensive model. Year 1, or Generation I, models focused on changes in $\mathrm{pH}$ and total dissolved solids (TDS) as a result of $\mathrm{CO}_{2}$ and brine intrusion into the aquifers via a single leakage point (leaking wellbore or fault leakage) (Dai et al. 2011; Bacon et al. 2012; Mansoor et al. 2012). Plume maps were drawn for each aquifer simulated based on the U.S. Environmental Protection Agency (EPA) National Secondary Drinking Water Regulation Limits for $\mathrm{pH}$ and TDS. ${ }^{1}$ The modeling teams identified aquifer impacts based on a pH decrease below 6.5 or an increase in TDS above $500 \mathrm{ppm}$. Feedback received from the NRAP Stakeholder Group indicated that an alternative approach to using either maximum contaminant level (MCL) or secondary drinking water standards as the threshold values to define impact was needed-one that reflects a change from current background levels (e.g., low levels) of key constituents in the aquifers.

The purpose of this study was to examine methodologies for establishing baseline data sets and statistical protocols for determining statistically significant changes between background concentrations and predicted concentrations that would be used to represent a contamination plume in the Generation II (Gen II) models being developed by NRAP's Groundwater Protection team. The primary objective was to evaluate the statistical variability of background groundwater concentrations of cadmium, lead, arsenic, $\mathrm{pH}$, and TDS in two selected underground sources of drinking water (USDW), and to determine "no-impact threshold values" that could be used to represent contamination due to predicted impacts from carbon sequestration storage reservoirs. Chromium was later added for determination of no-impact threshold values for the High Plains Aquifer, specifically to support the reduced order model (ROM) being developed by LLNL. Results from this effort will be used to inform a "no change" or "no impact" scenario with respect to groundwater impacts in those aquifers.

\subsection{Technical Scope and Approach}

The scope of the initial effort was to examine selected principal aquifers (as defined in the Ground-Water Atlas of the United States [USGS 1990-1999]) applicable to the sandstone and carbonaterock ROMs currently under development. Portions of two aquifer systems were selected for the initial investigation: the urban shallow-unconfined aquifer system of the Edwards-Trinity Aquifer System being

\footnotetext{
1 "Drinking Water Contaminants." Accessed on November 20, 2012, at http://water.epa.gov/drink/contaminants/index.cfm.
} 
used to develop the ROMs for carbonate-rock aquifers; and the central portion of the High Plains Aquifer (an unconsolidated and semiconsolidated sand and gravel aquifer) being used to develop the ROMs for sandstone aquifers.

Other principal sandstone or carbonate-rock aquifers identified for future investigation include the following:

- Colorado Plateau aquifers (sandstone aquifers)

- Pennsylvanian aquifers (sandstone aquifers in the central and eastern United States)

- Lower Tertiary aquifers (sandstone aquifers in the northern Great Plains)

- Ozark Plateau aquifer system (carbonate-rock aquifers in Missouri)

- Silurian-Devonian aquifers (carbonate-rock aquifers in the northern Midwest)

- Central Valley aquifer system (unconsolidated and semi-consolidated sand and gravel aquifers in California).

To expedite the development of no-impact threshold values needed to support completion of the Gen II ROMs, the team decided to start with the groundwater quality data sets used by Bacon (2012) and Bianchi et al. (2013). ${ }^{1}$ Bacon (2012) used data for the San Antonio Segment of the Edwards Aquifer, taken from appendices developed by Musgrove et al. (2010), using U.S. Geological Survey (USGS) National Water Quality Assessment (NAWQA) data collected in 1996-2006. The appendices of Musgrove et al. (2010) are available online at http://pubs.usgs.gov/sir/2010/5129/. Bianchi et al. (2013) ${ }^{1}$ used data downloaded directly from the NAWQA data warehouse website at http://co.water.usgs.gov/nawqa/hpgw/datarep/cos/COS.html.

The NAWQA data warehouse web interface provides access to chemical concentration data for water, bed sediment, and aquatic organism tissues for about 2,600 chemical constituents from 4,700 surface water sites and 9,500 wells. Most of these data came from the National Water Information System (NWIS) Water-Quality Data. The primary shortcoming from the data warehouse web interface is that the data are primarily limited to the NAWQA study areas and the data are not queriable online relative to their respective principal/national aquifer designation. Direct query of the NAWQA database was necessary to bin and screen the data by Principal (National) Aquifer designation and National Aquifer Code (from GW Atlas), Aquifer Class (from the GW Atlas), Primary aquifer (i.e., formation), and Aquifer type (i.e., shallow-unconfined, confined).

\subsection{No-Impact Threshold Values}

The objective of this study is to develop protocols for defining statistically valid no-impact threshold values indicative of a significant change in groundwater chemistry due to $\mathrm{CO}_{2}$ or brine leakage. The intent is to use these threshold values as an alternative to MCLs or secondary drinking water standards to

\footnotetext{
${ }^{1}$ Bianchi M, L Zheng, N Spycher, and J Birkholzzler. 2013, in press. Reduced Order Models for Prediction of Groundwater Quality Impacts from $\mathrm{CO}_{2}$ and Brine Leakage: Application to the High Plains Aquifer. NRAP Technical Report Series, U.S. Department of Energy, National Energy Technology Laboratory, Morgantown, West Virginia, p. 54.
} 
identify impacts predicted from the ROMs. Summaries of the data sets and statistical protocols used to calculate no-impact threshold values for the Edwards-Trinity and High Plains Aquifers are presented below.

\subsection{No-Impact Threshold Values for the Edwards-Trinity Aquifer}

The existing data set used by Bacon (2012) for the shallow/urban unconfined Edwards Aquifer, was used for no-impact threshold analysis. This data set was extracted from NAWQA data available as appendices to the Musgrove et al. (2010) report. Figure 1 illustrates the distribution of wells for the shallow, urban unconfined aquifer and approximates the domain used in the ROMs. Note that all data used in the analyses are within about $28 \mathrm{~km}(17 \mathrm{mi})$ of each other.

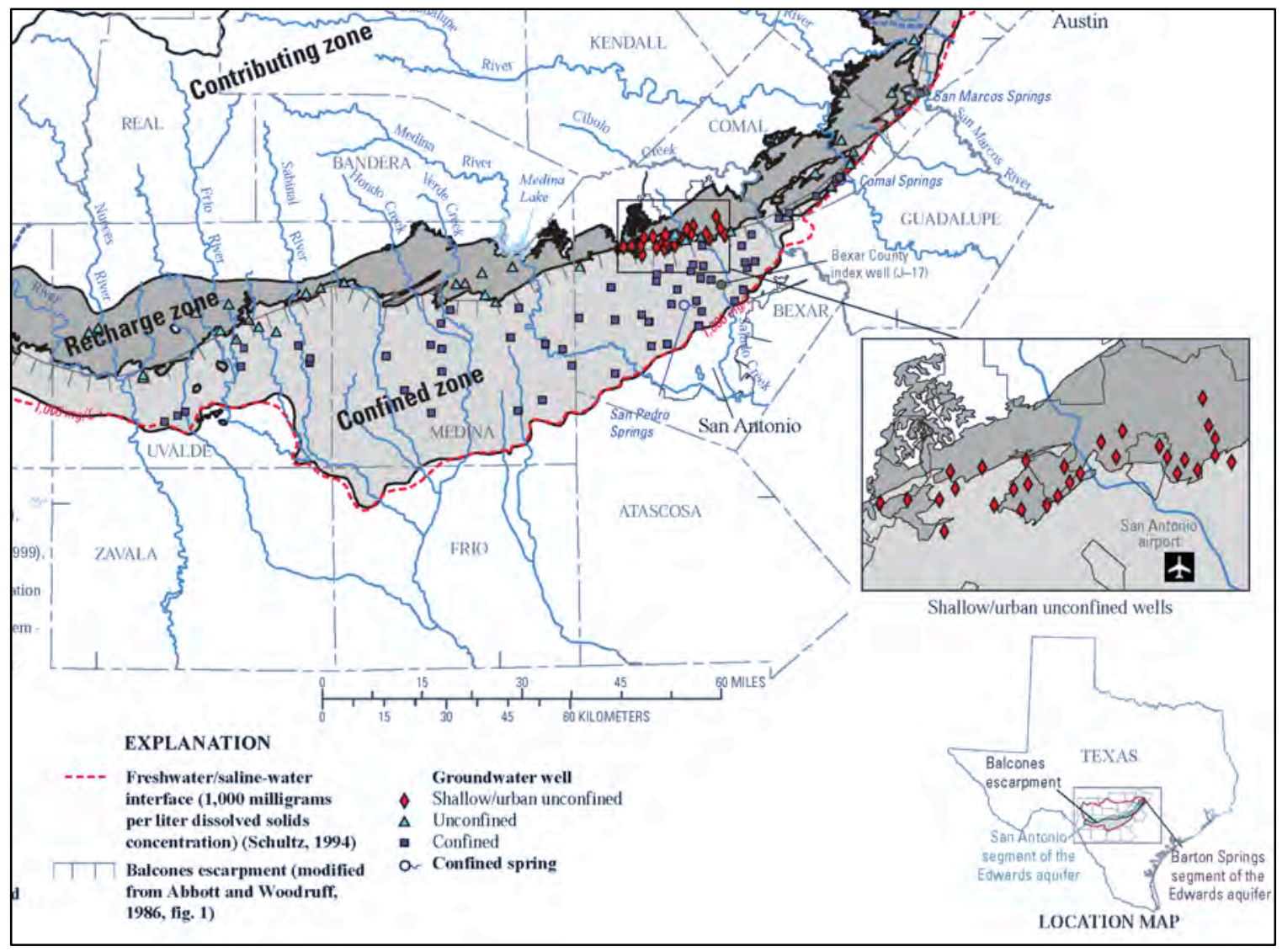

Figure 1. Location of shallow/urban unconfined wells for the Edwards Aquifer (taken from Musgrove et al. 2010).

This data set was screened and filtered to produce a "clean" data set for arsenic, cadmium, lead, $\mathrm{pH}$, and TDS. A brief analysis of the proportion of nondetects revealed that arsenic, cadmium, and lead were all below detection for almost all samples collected prior to 2001 (due in part to higher detection limits). Therefore, only the 49 data that were collected after the year 2000 were used for analysis of metals concentrations (Appendix A). Arsenic data for the post-2000 period were all above detection, about half were above detection for lead, and all data were below detection for cadmium. Statistics for $\mathrm{pH}$ and TDS were calculated on the full 90-sample data set for the shallow urban-unconfined aquifer (Appendix B); no 
statistically significant difference was found between data from 2000 and before and post-2000 data for those two variables, and all samples were above detection.

The initial goal of the no-impact threshold analysis was the identification of concentration limits that can be used to identify model grid cells that exhibit contamination during reactive transport groundwater modeling runs. Based on guidance from NRAP's stakeholder group, it was determined that an alternative to using the MCLs for this comparison was needed, one based on a statistically significant increase or decrease (for $\mathrm{pH}$ ) relative to background. Recommendations found in the EPA's Unified Guidance for Statistical Analysis of Groundwater Monitoring Data at RCRA Facilities (EPA 2009) were used to identify useful statistics for that purpose. Section 7.5 of that document suggests that a reasonable statistic for single-sample testing against a fixed groundwater protection standard (GWPS) based on background would be a background upper tolerance limit with $95 \%$ confidence and $95 \%$ coverage. The GWPS determined using this approach can be interpreted as an approximation to the upper 95th percentile of the background distribution. It is designed to be a reasonable maximum on the likely range of background concentrations. If the data have a normal or lognormal distribution and have a small proportion of nondetects, then a parametric tolerance limit is suggested (EPA 2009). For larger fractions of nondetects, a nonparametric tolerance limit is recommended in the EPA Guidance (EPA 2009). For pH, it was assumed that a background lower tolerance limit with $95 \%$ confidence and $95 \%$ coverage would be the proper statistic because the concern is with decreases in $\mathrm{pH}$ that would denote a change in aquifer chemistry by infiltrating $\mathrm{CO}_{2}$.

The open-source statistical software system "R," version 2.14.1 (R Development Core Team 2012), was used for statistical analysis. In addition to the base $\mathrm{R}$ installation, the $\mathrm{R}$ package, "tolerance" (Young 2010), was used to calculate the parametric and nonparametric tolerance intervals. The R package "NADA" (Lee 2012) was used to calculate statistics that account for the presence of nondetects in the data, following the methodology published by Helsel (2012).

The resulting tolerance limits (i.e., no-impact threshold values) for the relevant variables are contained in Table 1, along with assumptions that were made in developing those tolerance limits. The arsenic data exhibited a slight positive skewness (Figure 2), so a lognormal distribution was assumed and a parametric upper tolerance limit was calculated. The assumption of a lognormal distribution for contaminant concentration data is very common (Davis 2002). Given the high proportion of nondetects for the lead data $(\sim 50 \%)$, a nonparametric upper tolerance limit was calculated. Because no data above the detection limit were available for cadmium, the upper tolerance limit was set equal to the detection limit reported for the data. Thus, a cadmium concentration value above the detection limit would indicate the presence of contamination during a groundwater-modeling run. The $\mathrm{pH}$ and TDS data were relatively symmetrical (Figure 3 and Figure 4), so a normal distribution was assumed for each variable (Table 1).

Table 1. Tolerance limits for concentrations in the urban portion of the unconfined Edwards Aquifer.

\begin{tabular}{ccccccc}
\hline & Percent & Assumed & & & \\
Analyte & Nondetects & Interval Type & Distribution & Upper/Lower $^{(\mathrm{a})}$ & Value & Units $^{-}$ \\
\hline Arsenic & 0 & Parametric & Lognormal & Upper & 0.55 & $\mu \mathrm{g} / \mathrm{L}$ \\
Cadmium & 100 & NA & NA & Upper & 0.04 & $\mu \mathrm{g} / \mathrm{L}$ \\
Lead & 51 & Nonparametric & NA & Upper & 0.15 & $\mu \mathrm{g} / \mathrm{L}$ \\
pH & 0 & Parametric & Normal & Lower & 6.6 & $-\log \left\{\mathrm{H}^{+}\right\}$ \\
TDS & 0 & Parametric & Normal & Upper & 420 & $\mathrm{mg} / \mathrm{L}$ \\
\hline (a) Rounded to two significant digits. & & & & \\
\hline
\end{tabular}




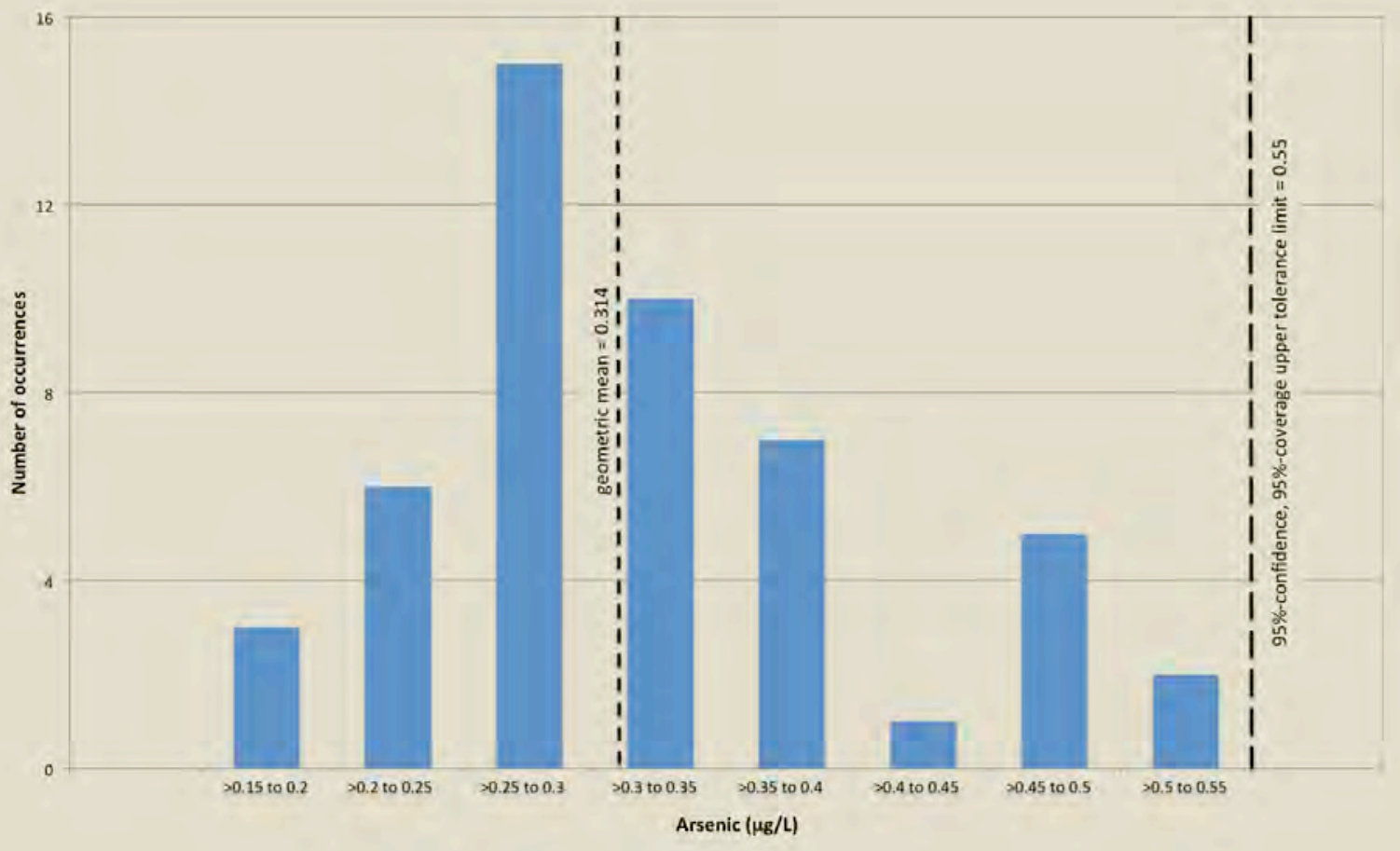

Figure 2. Histogram of arsenic concentrations for post-2000 samples from shallow/urban unconfined Edwards Aquifer.

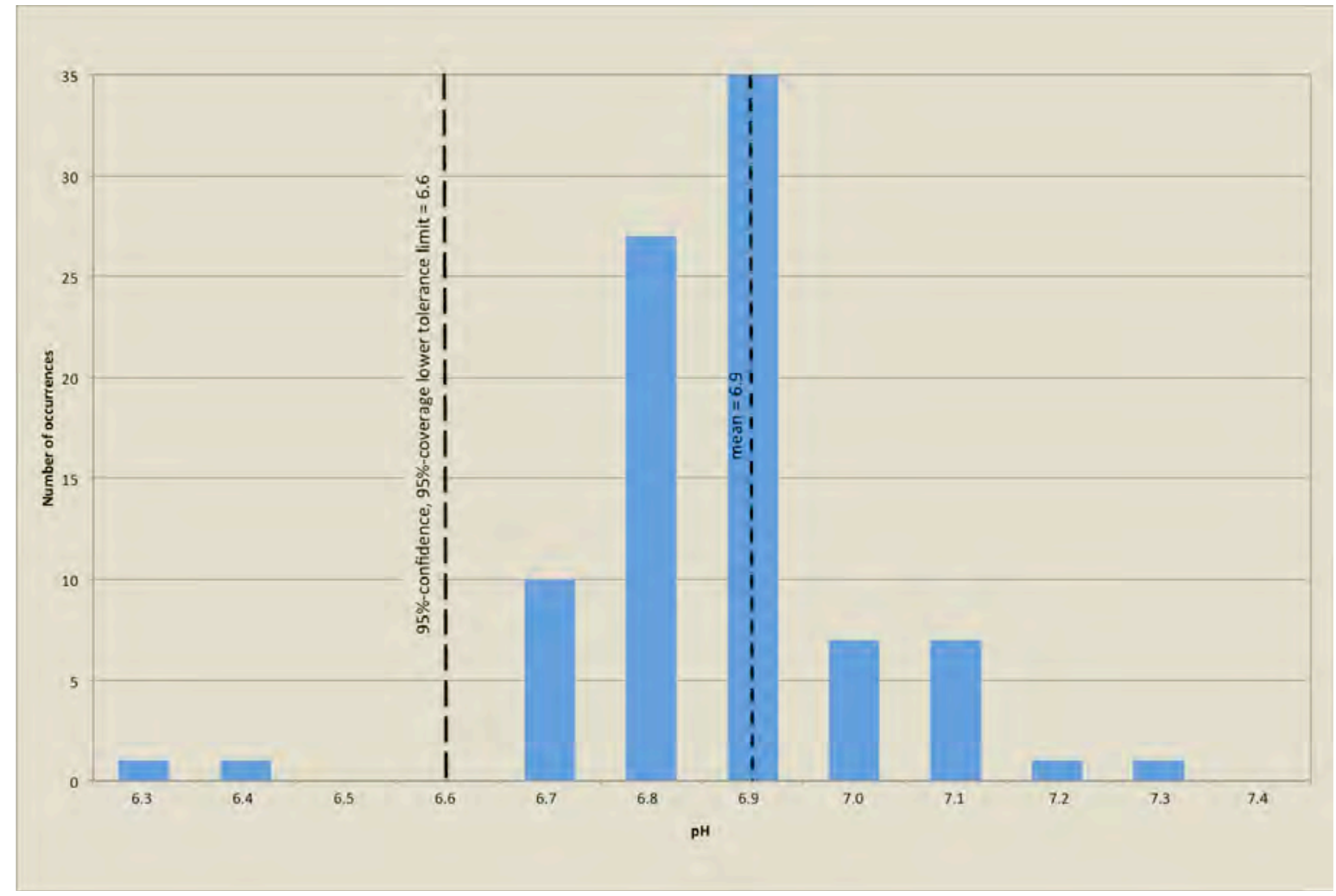

Figure 3. Histogram of $\mathrm{pH}$ values for all samples from shallow/urban unconfined Edwards Aquifer. 


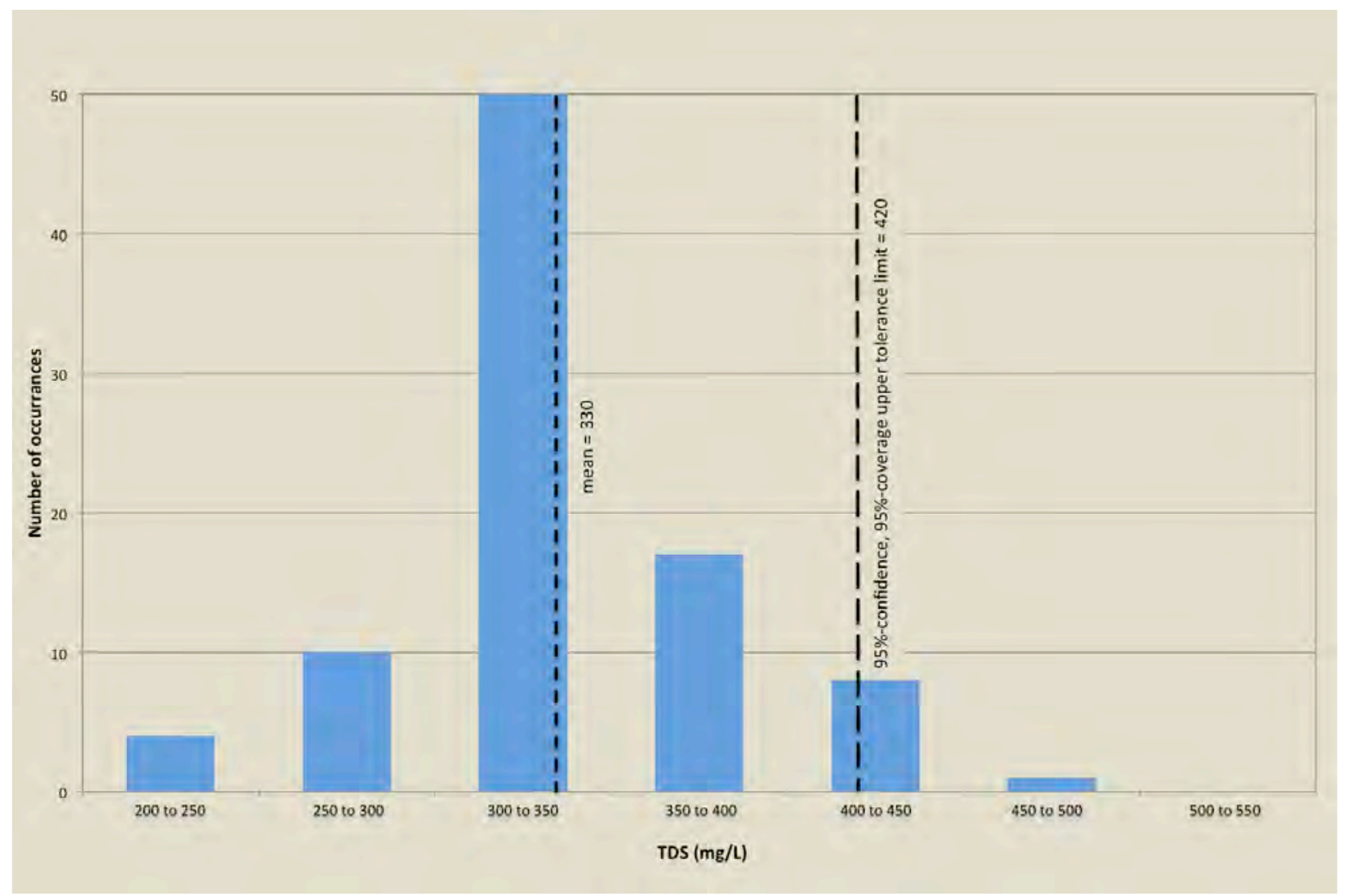

Figure 4. Histogram of TDS concentrations for all samples from shallow/urban unconfined Edwards Aquifer.

Initial concentration values for each variable were also needed for initialization of the Gen II modeling runs. These initial values were calculated using the same data sets that form the basis for Table 1, and were assumed to be uniform over the entire modeling domain. Given the assumption of a lognormal distribution for arsenic, the geometric mean of the data of $0.314 \mu \mathrm{g} / \mathrm{L}$ was recommended as an initial value (Table 2). No data above the detection limit were available for cadmium, so a value of zero was assumed as a reasonable initial condition. The lead data were highly skewed and had a large percentage of nondetects, so the "NADA" package was used to estimate a median value for the lead data using the regression on order statistics (ROS) method (Table 2). Given the symmetric distributions for $\mathrm{pH}$ and TDS, the mean values were used as initial values for the modeling runs. The tolerance limits and regulatory standards are provided for comparison to the initial values in Table 2. The regulatory standards for the metals are the EPA's MCLs; the standards for pH and TDS are from the list of National Secondary Drinking Water Regulations. The MCLs and secondary standards were taken from the EPA's Drinking Water Contaminants website (http://water.epa.gov/drink/contaminants/index.cfm). The tolerance limits for identification of contaminated drinking water in the urban unconfined Edwards Aquifer are all significantly less than the MCLs or secondary standards (Table 2). The tolerance limits for the metals based on background data are all at least an order of magnitude less than the corresponding MCLs. Thus, they should address the concerns of the NRAP Stakeholder's Group by providing target levels that provide a level of protection based on existing background data, which are well below regulatory limits. 
Table 2. Initial values, tolerance limits, and regulatory standards for each variable.

\begin{tabular}{lcccc}
\hline Analyte & $\begin{array}{c}\text { Initial } \\
\text { Value }^{(\mathrm{a})}\end{array}$ & $\begin{array}{c}\text { Tolerance } \\
\text { Limits }^{(\mathrm{a})}\end{array}$ & Regulatory Standard & Units \\
\hline Arsenic & 0.31 & 0.55 & 10 & $\mu \mathrm{g} / \mathrm{L}$ \\
Cadmium & 0 & 0.04 & 5 & $\mu \mathrm{g} / \mathrm{L}$ \\
Lead & 0.064 & 0.15 & 15 & $\mu \mathrm{g} / \mathrm{L}$ \\
$\mathrm{pH}$ & 6.9 & 6.6 & 6.5 & $-\log \left\{\mathrm{H}^{+}\right\}$ \\
TDS & 330 & 420 & 500 & $\mathrm{mg} / \mathrm{L}$ \\
\hline
\end{tabular}

(a) Rounded to two significant digits.

An issue that was not addressed in the determination of the initial values and tolerance limits is that of spatial stationarity of the data. The EPA Unified Guidance suggests that analysis of variance (ANOVA) be used to examine data from proposed background wells to determine if the data exhibit spatial variability, such that the mean and variance of the concentrations varies between background wells. If the data exhibit spatial variability of the mean or variance, then the use of intrawell comparisons would be recommended for identification of significant increases in concentrations due to the monitored facility (EPA 2009) in a standard Resource Conservation and Recovery Act of 1976 (RCRA) analysis. However, the use of background data in the NRAP groundwater modeling study is very different from the use in RCRA in that the goal was to use existing well data in the model area to initialize the groundwater models, and then quantify the number of model cells (if any) that exceed a no-impact threshold or tolerance limit to identify the size of the "plumes" caused by $\mathrm{CO}_{2}$ or brine migration into the aquifer. The initial values for the groundwater model runs are assumed to be homogeneous over the model area. The comparison of modeled concentrations with the tolerance limits are made at all cells in the modeling grid, so the tolerance limits should reflect the variability in background concentration data found over the entire study area. Thus, the comparison approach to identification of contamination is different from the upgradient/downgradient comparisons that are typically made for a RCRA facility, and the assumption of a uniform threshold based on background data to identify significant changes to aquifer chemistry appears to be reasonable.

The approach taken for this study was to identify an upper (or lower) tolerance limit for each variable that reflects the variability in the existing data set and can be interpreted as an approximation to the upper (or lower) 95th percentile of the existing distribution. It is designed to be a reasonable maximum on the likely range of background concentrations, as an alternative to the use of an MCL as an upper limit. Thus, the spatial stationarity of the background data does not appear to be relevant to the current use of the background data. This is especially true given the limited spatial extent of the Edwards Aquifer data (Figure 1), which is much less than the spatial extent of the sample set used to derive threshold values for the High Plains Aquifer, as discussed in the following section.

\subsection{No-Impact Threshold Values for the High Plains Aquifer System}

The High Plains Aquifer extends from South Dakota to Texas, as shown in Figure 5. The hydrology and groundwater quality of the aquifer was studied during the NAWQA Program. Studies were based on 
statistical segmentation of the aquifer. The first segmentation was into northern, central, and southern major subregions based on climatological data. The second segmentation was based on hydrogeologic units (McMahon et al. 2007).

NRAP is numerically simulating $\mathrm{CO}_{2}$ and brine leakage into the High Plains Aquifer at the location shown on Figure 5. The groundwater models for this area simulate the resulting change in groundwater chemistry. The models are for the Ogallala Formation in the central High Plains Aquifer.

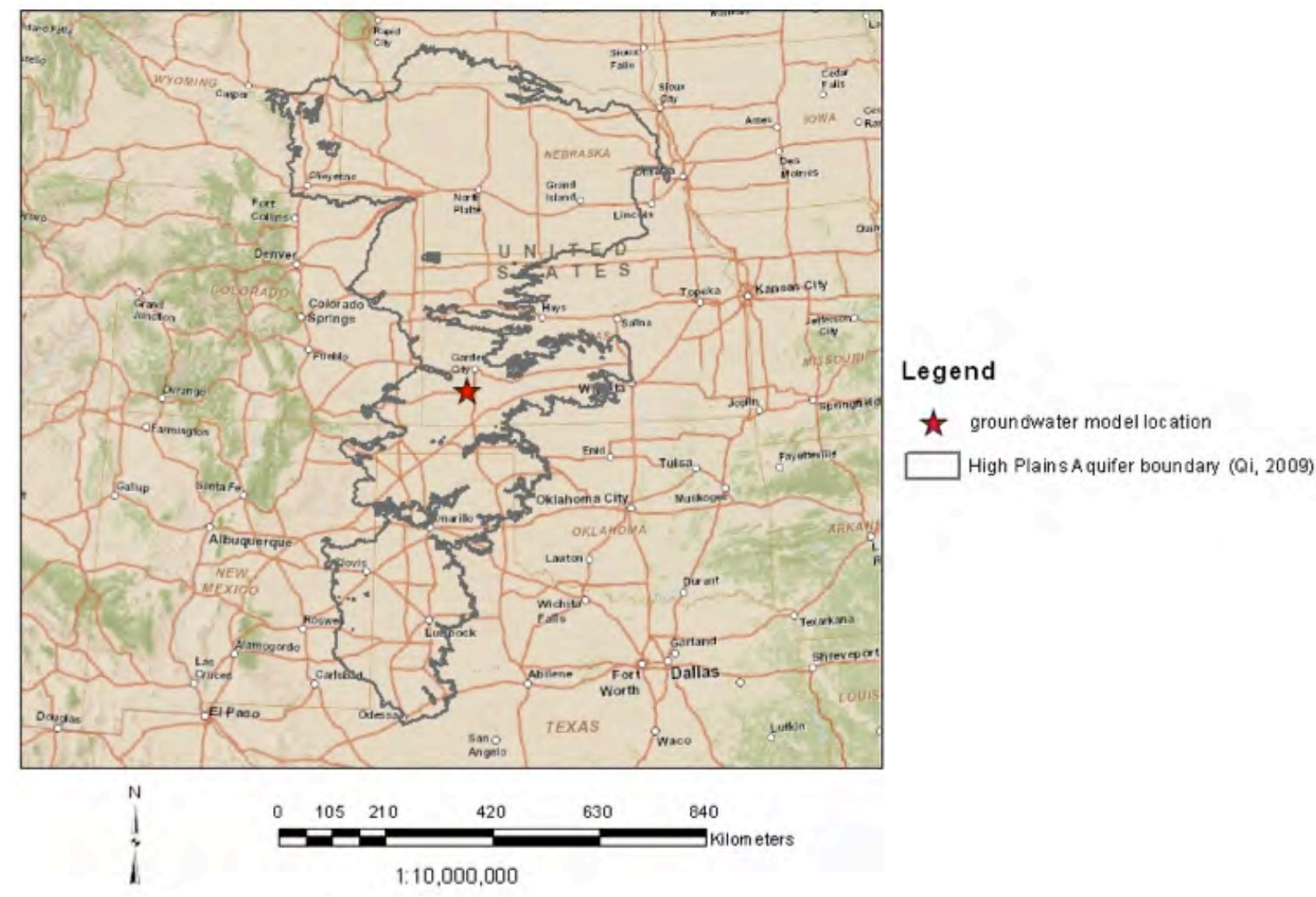

Figure 5. High Plains Aquifer and groundwater model location.

\subsubsection{Data Sources}

Numerous potential sources of groundwater data were investigated. The EPA operates a water quality database called STORET (http://www.epa.gov/storet/). It contained no groundwater quality data in the vicinity of the model location as of 7 December 2012.

The Kansas Geological Survey (KGS) operates several databases that bear on various aspects of groundwater. The Water Information Management and Analysis System (WIMAS;

http://hercules.kgs.ku.edu/geohydro/wimas/index.cfm) contains water rights data, including the location of water wells. Figure 6 shows the water well locations contained in WIMAS as of 7 December 2012 within the model area and vicinity. 


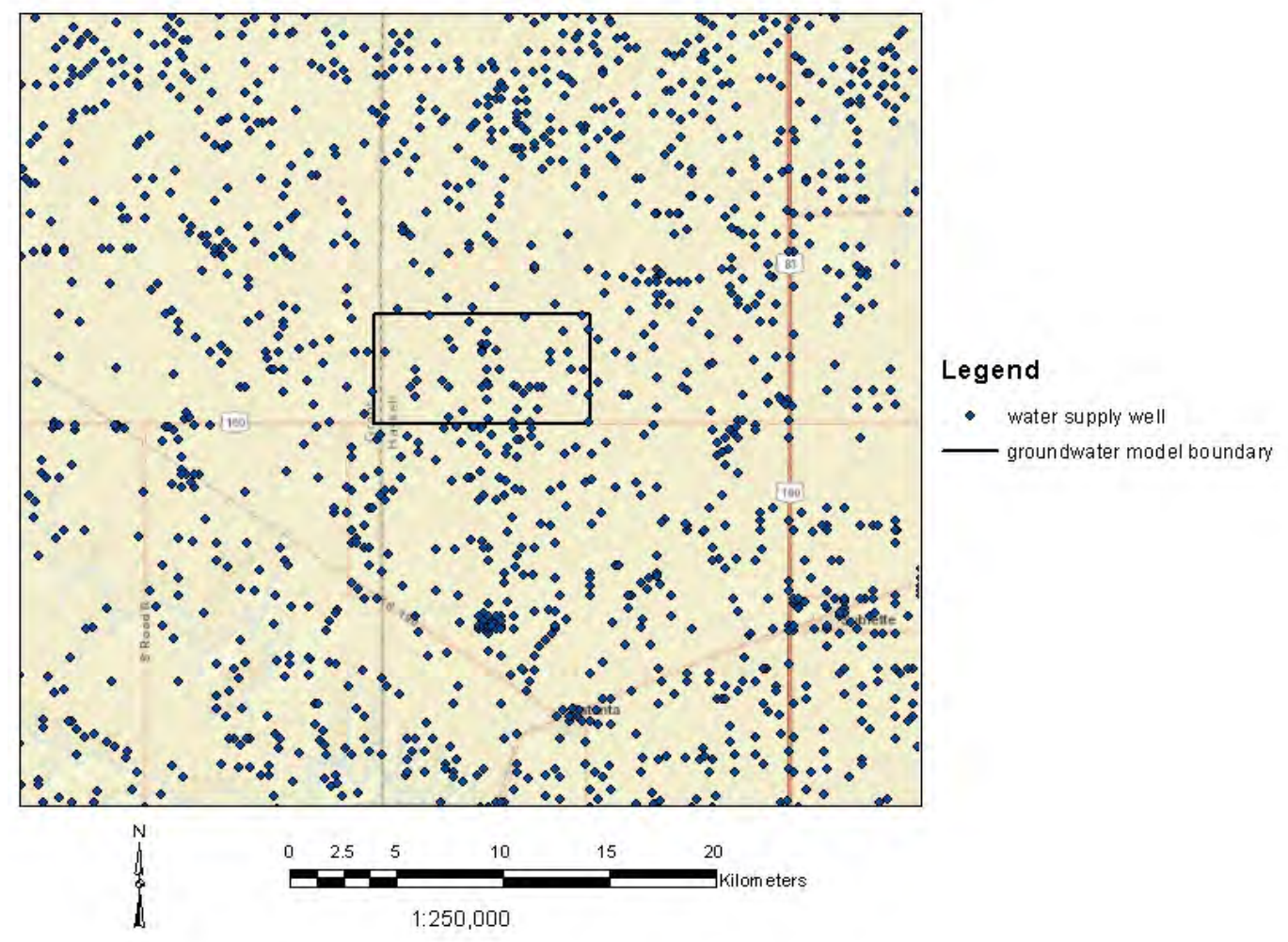

Figure 6. Groundwater model location and water supply wells.

However, none of the KGS databases or reports appears to have data on the parameters of interest at the model site or across the aquifer around the model site. One report does include TDS data, but only for counties south of those containing the model site (Whittemore 2005). These data were from samples collected during a 60 -year period, and compiled from a variety of sources. These factors suggest these data should not be applied to the model site if there are alternatives.

The entire High Plains Aquifer was studied as part of the NAWQA conducted by the USGS. The study actually consisted of several "nested" studies. The goal of this nesting was to efficiently characterize groundwater conditions and processes affecting those conditions. The nesting consisted of four study types, each using different types of wells. Unsaturated zone studies collected data relevant to the fate and transport of constituents in waters recharging from the land surface from sampling points screened above the water table. Land use studies collected data relevant to understanding the impact of water recharging from the land surface on groundwater quality from wells screened at the water table. Transect studies collected data relevant to understanding vertical groundwater flow and characterizing groundwater quality with depth in the aquifer from groups of wells screened at different levels in the aquifer located on a transect parallel to gradient. Major aquifer studies collected data relevant to characterizing groundwater conditions across the aquifer from randomly selected private supply wells, which are generally screened below the water table (McMahon et al. 2007).

These studies found groundwater quality was more variable at the water table than deeper in the High Plains Aquifer, presumably due to recharge of anthropogenically-altered water from the land surface (Gurdak et al. 2009). The four types of nested studies were conducted specifically for the Ogallala unit of the Central High Plains Aquifer. As with the High Plains Aquifer as a whole, the transect study of the 
Ogallala in the Central High Plains Aquifer, which was located along the border between Kansas and Oklahoma, generally found greater variation in groundwater quality at the water table than deeper in the aquifer (McMahon 2001).

The High Plains regional groundwater study website indicates the 74 wells used in the major aquifer study were sampled in 1999 and a subset of 30 wells was resampled in 2010 (http://co.water.usgs.gov/nawqa/hpgw/datarep/cos/COS.html, accessed 7 December 2012). Richard Bell at the USGS queried the NAQWA database for inorganic constituent, $\mathrm{pH}$, and TDS data for High Plains Aquifer groundwater. These data were loaded into a relational database, along with tables of the well identification numbers for each of the studies in the Ogallala unit of the Central High Plains Aquifer. This allowed querying the data provided for the list of wells used in each study, as well as facilitating construction of tables for each constituent for spatial and statistical analysis. These queries resulted in identification of a third sampling event for the major aquifer study wells that took place in 2012. However, only five major aquifer study wells were resampled in this event, so these data were not considered further.

Further querying concluded the only data for the Central High Plains Ogallala unit outside of the well groups used in the four types of studies was from a group of public supply wells. These were the subject of another study comparing water quality from these wells with that from paired, nearby private supply wells. Given the typically different construction (longer screens) and pump rate (higher) for the public supply wells compared to the major aquifer study wells, data from the public supply wells was not utilized in this study.

The generally greater variation in water quality at the water table rather than deeper in the aquifer is illustrated by comparing the $\mathrm{pH}$ results from the major aquifer and irrigated agricultural land use study wells shown on Figure 7 and Figure 8. The 2010 results from the subset of major aquifer study wells that were resampled are shown in Figure 7. They are generally spatially correlated and indicate a trend in $\mathrm{pH}$ across the site from higher values in the west to lower in the east. Figure 8 shows the 2000 irrigated agriculture land use results, which cover a smaller area, and are not as spatially correlated. This is particularly so where the sampling density is highest northeast of the model area, further suggesting a lack of spatial correlation.

To the extent monitoring for groundwater quality changes due to leakage might occur, monitoring points would likely be located deeper in the aquifer to provide for earlier detection. Such monitoring might use newly installed wells, appropriately located existing private supply wells, or a mixture of the two. Given the existence of numerous private supply wells in the area, it is also likely groundwater quality changes might be detected first at such a well that may not be part of a regular leakage detection monitoring program.

For reasons of aquifer position, well type, greater uniformity of spatial data density and data values, and geographic coverage around the study site, 1999 and 2010 data from the major aquifer study wells were selected as the basis for groundwater impact threshold development. These data are included in Appendix C. The 2010 data from the major aquifer study wells were selected to be representative of recent conditions should there have been a temporal trend in any of the parameter values. The 1999 and 2010 results from the 30 major aquifer wells sampled at both times are compared in a discussion section below. All future references to these data will not include the phrase "major aquifer study." 


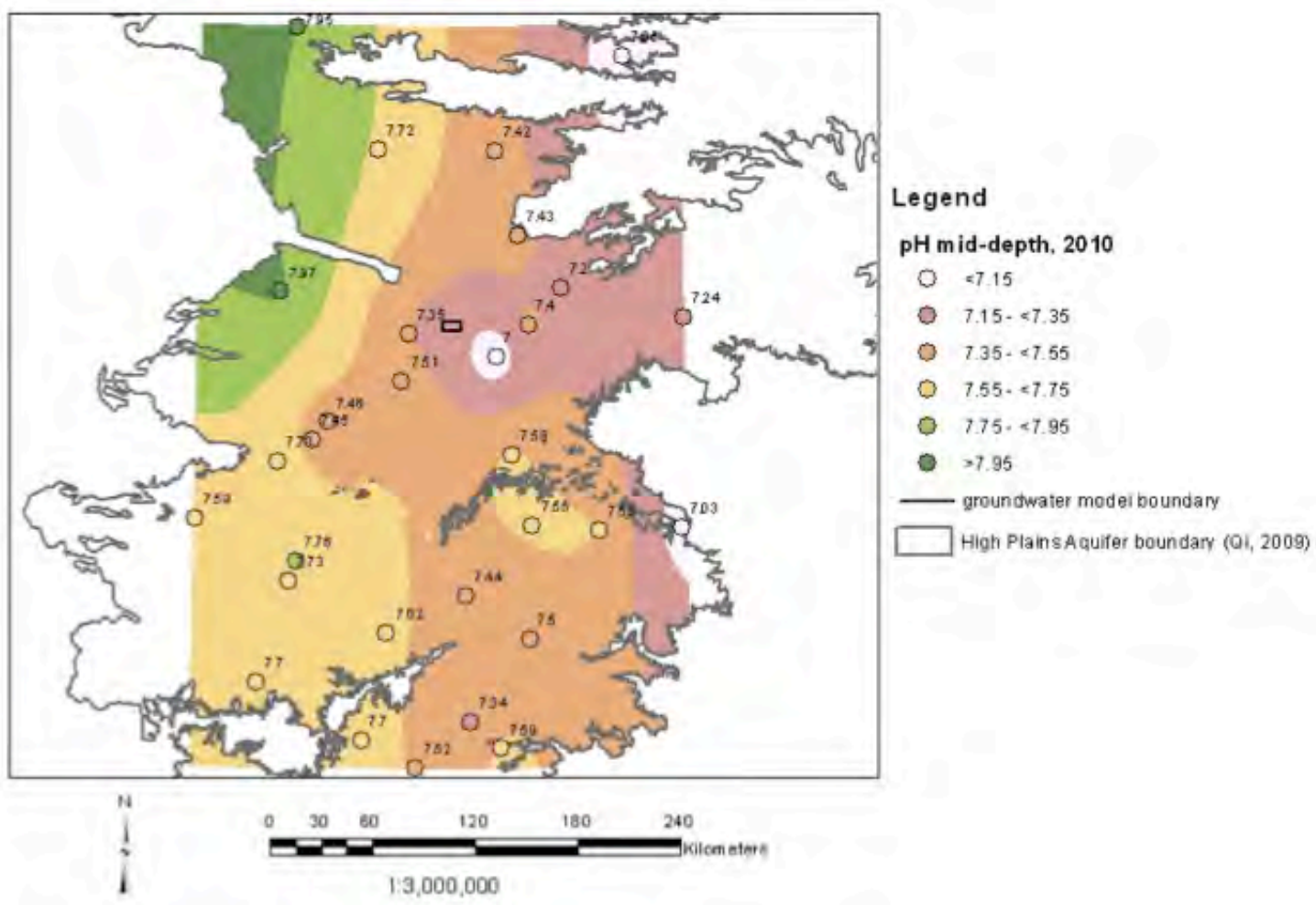

Figure 7. Resampled major aquifer study well pH in 2010 superimposed on contours resulting from kriging with a spherical variogram.

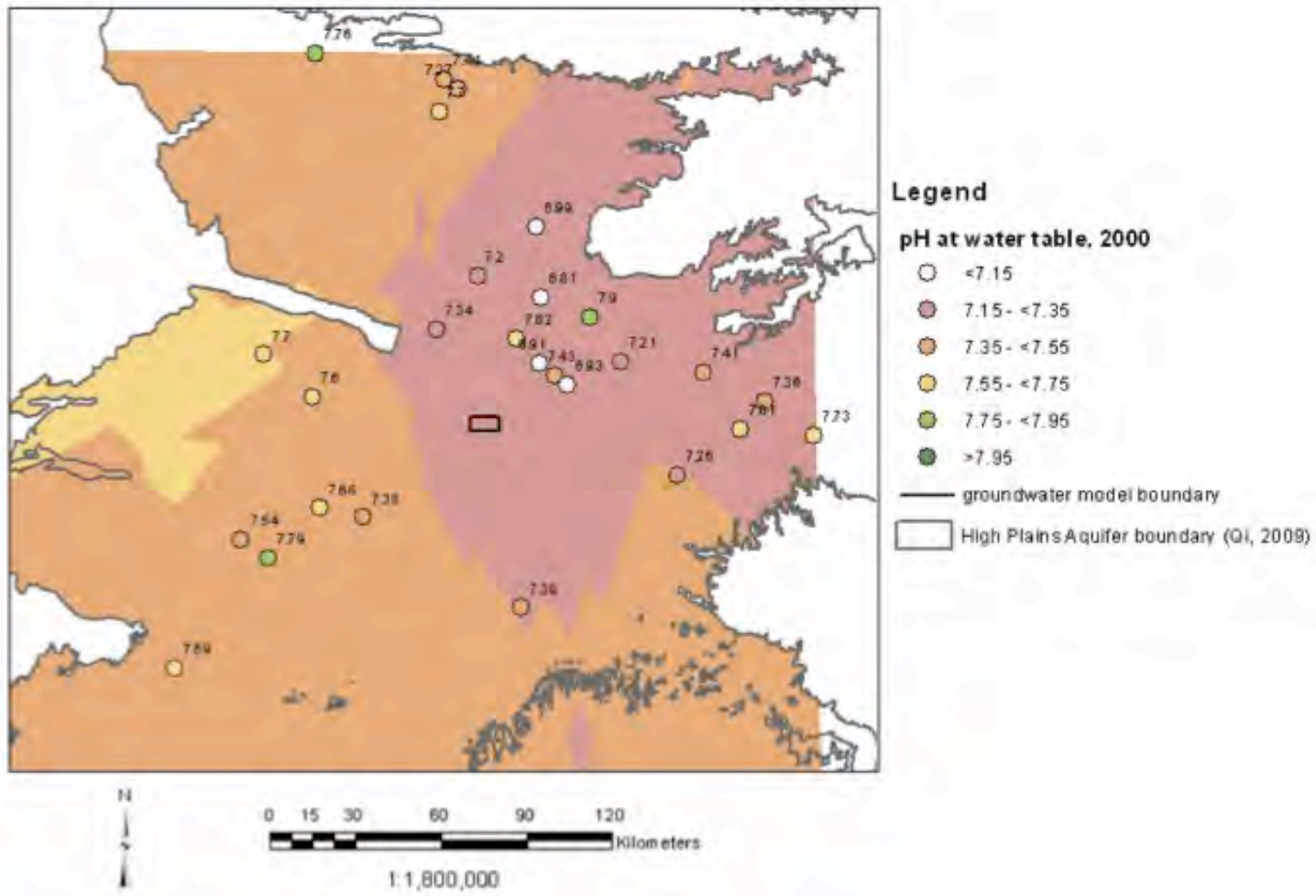

Figure 8. Irrigated agriculture study well $\mathrm{pH}$ in 2000 superimposed on contours resulting from kriging with a spherical variogram. 


\subsubsection{No-Impact Threshold Summary}

The no-impact threshold values for the central portion of the High Plains Aquifer to be used for mapping significant changes in the groundwater quality parameters considered by NRAP in the Gen II integrated risk assessment are given in Table 3. These are the 95\%-confidence, $95 \%$-coverage tolerance limits similar to those developed for the Edwards Aquifer (Section 3.1). The threshold values were based on the data sets selected, as described below, excluding outliers. Note that all the selected data are located some distance (tens of kilometers) from the model domain.

Table 3. No-impact thresholds for the High Plains Aquifer models based on sample data.

\begin{tabular}{lcccc}
\hline \multicolumn{1}{c}{ Analyte } & $\begin{array}{c}\text { Initial Value } \\
\text { Used in Gen II ROMs }^{(\mathrm{a})}\end{array}$ & $\begin{array}{c}\text { Mean of Selected and } \\
\text { Adjusted 2010 Data }^{(\mathrm{b})}\end{array}$ & $\begin{array}{c}\text { Threshold } \\
\text { Concentration }^{(\mathrm{c})}\end{array}$ & $\begin{array}{c}\text { Regulatory } \\
\text { Standard }\end{array}$ \\
\hline $\mathrm{pH}$ & 7.4 & $7.5^{(\mathrm{d})}$ & $7.0^{(\mathrm{d})}$ & 6.5 \\
Total Dissolved & $430 \mathrm{mg} / \mathrm{l}^{(\mathrm{d})}$ & $440 \mathrm{mg} / \mathrm{l}^{(\mathrm{d})}$ & $1300 \mathrm{mg} / \mathrm{l}^{(\mathrm{d}, \mathrm{e})}$ & $500 \mathrm{mg} / \mathrm{l}^{(\mathrm{e})}$ \\
Solids & $2.9 \mu \mathrm{g} / \mathrm{l}^{(\mathrm{d})}$ & $1.5 \mu \mathrm{g} / \mathrm{l}^{(\mathrm{d})}$ & $9.3 \mu \mathrm{g} / \mathrm{l}^{(\mathrm{d})}$ & $10 \mu \mathrm{g} / 1$ \\
Arsenic & $0.078 \mu \mathrm{g} / \mathrm{l}^{(\mathrm{d})}$ & $0.059 \mu \mathrm{g} / 1$ & $0.25 \mu \mathrm{g} /$ & $5 \mu \mathrm{g} / 1$ \\
Cadmium & $0.0^{(\mathrm{f})}$ and $1.0^{(\mathrm{a})} \mu \mathrm{g} / 1$ & $1.0 \mu \mathrm{g} / 1$ & $3.9 \mu \mathrm{g} / 1$ & $100 \mu \mathrm{g} / 1$ \\
Chromium (total) & $0.32 \mu \mathrm{g} / \mathrm{l}^{(\mathrm{d})}$ & $0.086 \mu \mathrm{g} / 1$ & $0.63 \mu \mathrm{g} / 1$ & $15 \mu \mathrm{g} / 1$ \\
Lead &
\end{tabular}

(a) Liange Zheng, personal communication via email dated December 13, 2012 and January 28, 2013.

(b) Geometric mean except for $\mathrm{pH}$, which is already a log value.

(c) $95 \%$-confidence, $95 \%$-coverage tolerance limit based on $\log$ values except for $\mathrm{pH}$, which is already a $\log$ value. See text for explanation of whether threshold value is based on upper or lower limit.

(d) Rounded to two significant digits.

(e) Threshold value exceeds regulatory standard, however using the regulatory standard may result in widespread false positives under field conditions (see Section 3.2.4).

(f) Susan Carroll, personal communication via email dated January 28, 2012.

A concern during subsurface sequestration is that brine and $\mathrm{CO}_{2}$ leakage from the target reservoir into shallower USDWs will cause an increase in all parameters of interest except $\mathrm{pH}$, for which the concern is a decrease. Consequently, the no-impact threshold is the upper tolerance limit for all parameters except $\mathrm{pH}$, for which the threshold is the lower limit. All the data sets were log normal (noting $\mathrm{pH}$ is a $\log$ concentration), so parametric tolerance limits provided the thresholds. The tolerance limits for the High Plains data were computed using a spreadsheet (http://statpages.org/tolintvl.xls) that implemented the National Institute of Standards/SEMATECH description of tolerance limits for a normal distribution (National Institute of Standards/SEMATECH 2012). The software implementations of tolerance limits used for the Edwards and High Plains data are equivalent, and comparison of upper tolerance limits computed using tolintvl.xls and R's normtol.int function showed very close agreement.

The mean values from each selected data set are also included for use in initialization of the next generation (i.e., Gen II.1) modeling runs. Outliers were excluded from both calculations. Outliers were defined as values greater than the 75 th percentile plus 1.5 times the interquartile range or less than the 25 th percentile minus 1.5 times the interquartile range. Given the parameters in the groundwater in some locations are likely due to anthropogenic perturbations superimposed on natural processes discussed above, outliers are expected. 


\subsection{3 $\mathrm{pH}$}

Figure 9 shows the $2010 \mathrm{pH}$ data selected for calculating the threshold. The selected data are within $95 \mathrm{~km}$ of the model site. This set was selected because the spatial correlation and trend was weaker in this area than in the data set overall. Figure 10 shows the distribution of the selected data. Given the small sample size, this distribution is consistent with a normal distribution. The mean and lower tolerance were calculated for the selected set.

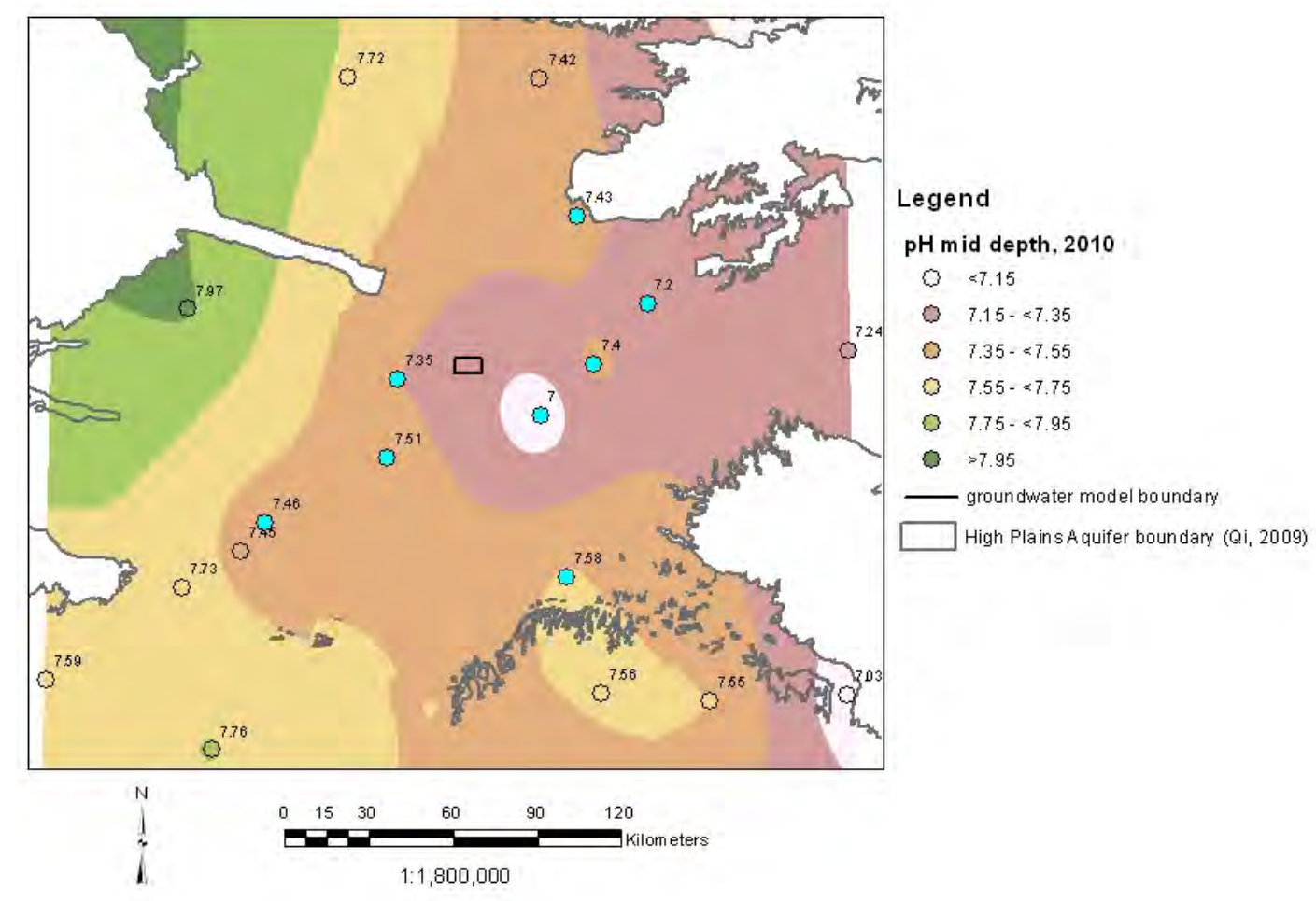

Figure 9. Results for $\mathrm{pH}$ in 2010 from resampled major aquifer study wells with data selected for threshold calculation indicated in blue. 


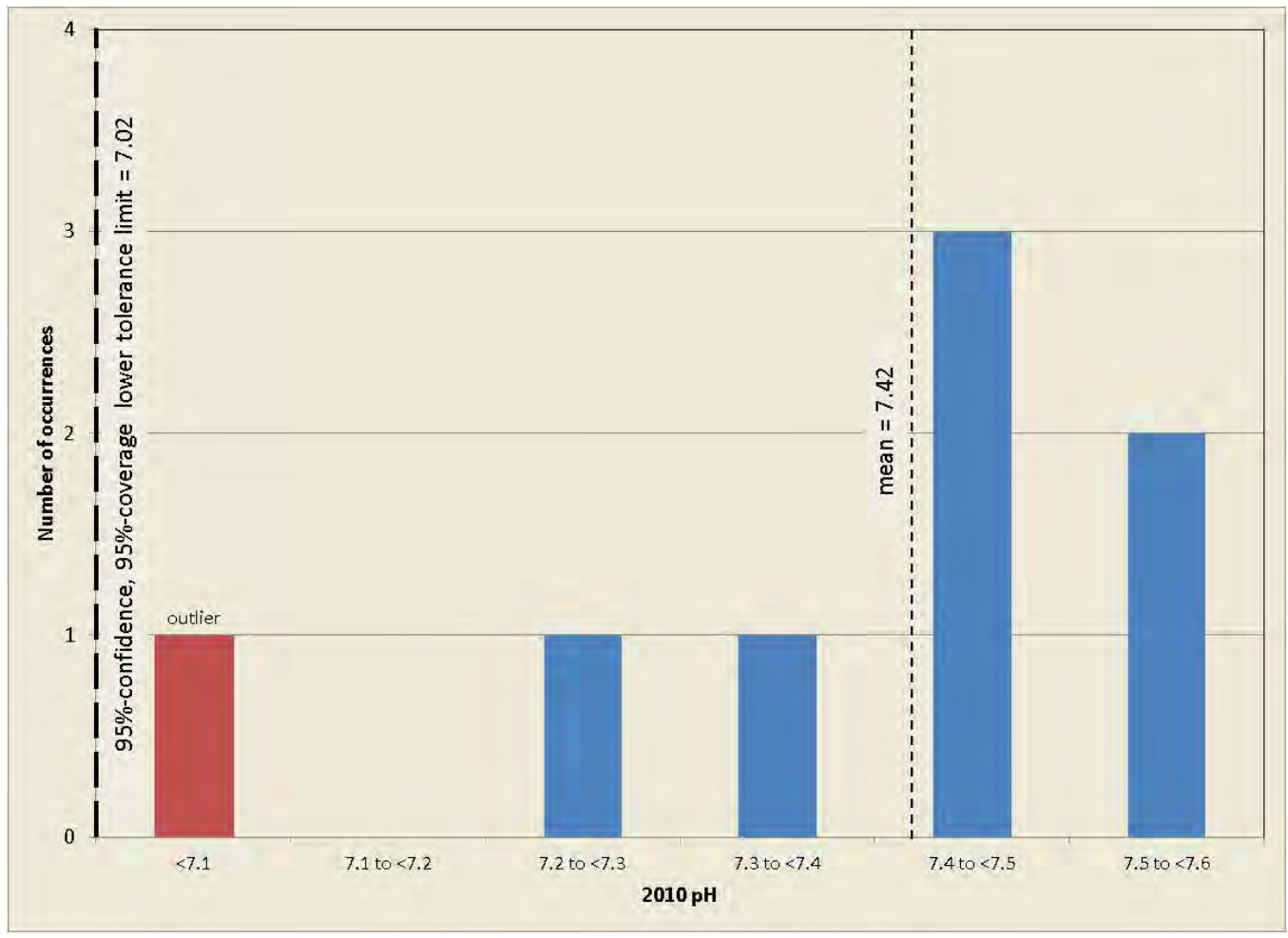

Figure 10. Histogram of selected $\mathrm{pH}$ in 2010 from major aquifer study wells.

\subsubsection{Total Dissolved Solids}

The 2010 TDS data are mapped on Figure 11. There is a general trend from higher TDS in the north to lower in the south. Values to the south of the model area are more spatially correlated and more correlated to this trend than are values around the model and to the north. The values in the northern area indicated in Figure 11 were used in threshold development. Note that 7 of the 15 samples selected for calculating the threshold exceeded the $500 \mathrm{mg} / \mathrm{l}$ secondary drinking water standard for TDS, with the maximum concentration estimated at $955 \mathrm{mg} / \mathrm{l}$.

Figure 12 shows the distribution of the log of the selected data. Given the small sample size, this distribution is consistent with normal distribution. Consequently, the geometric mean and upper tolerance limit were calculated from the log of the data. 


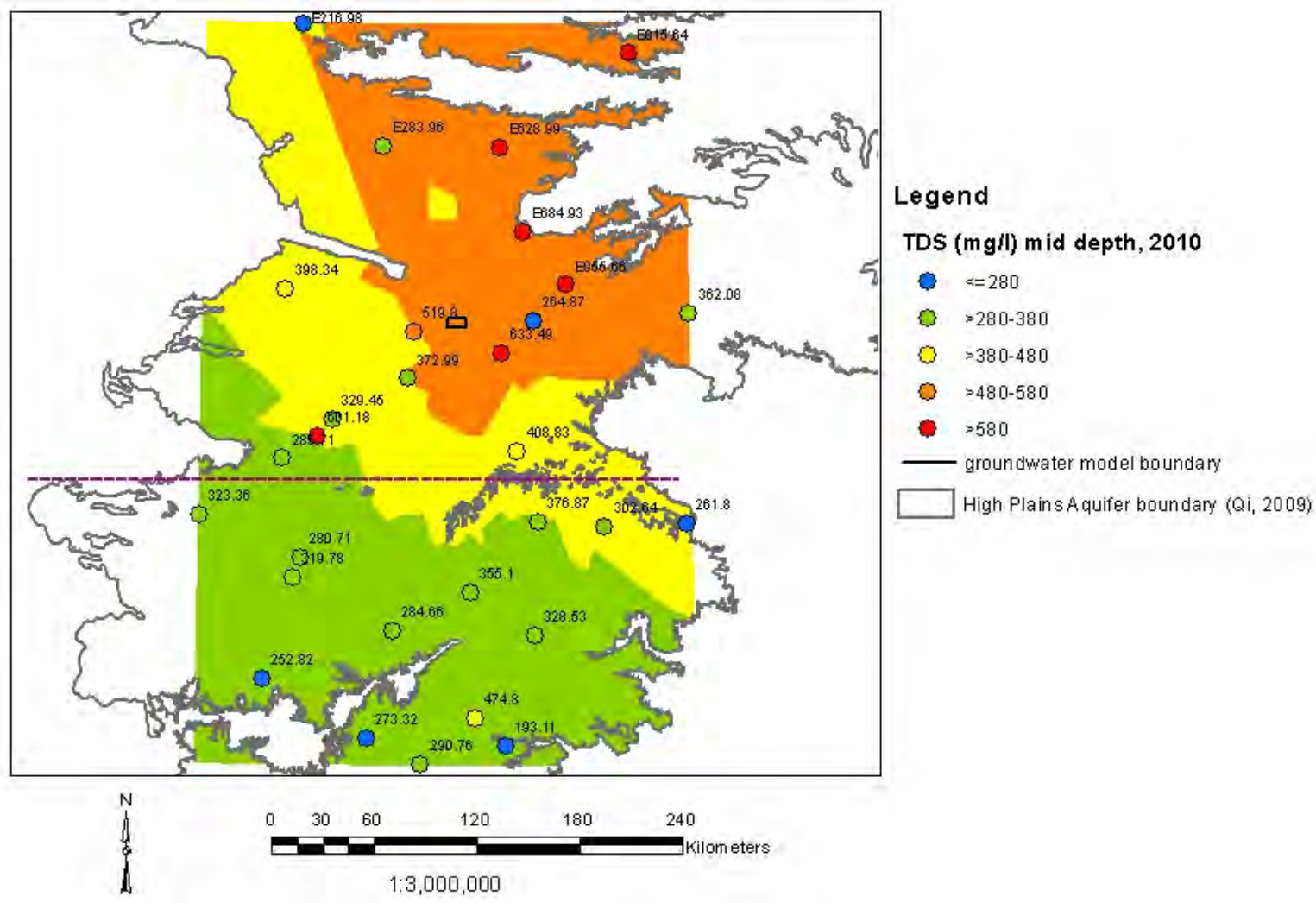

Figure 11. Results for TDS in 2010 from resampled major aquifer study wells superimposed on contours resulting from kriging with a spherical variogram. Values north of the purple dashed line were used for calculating the threshold.

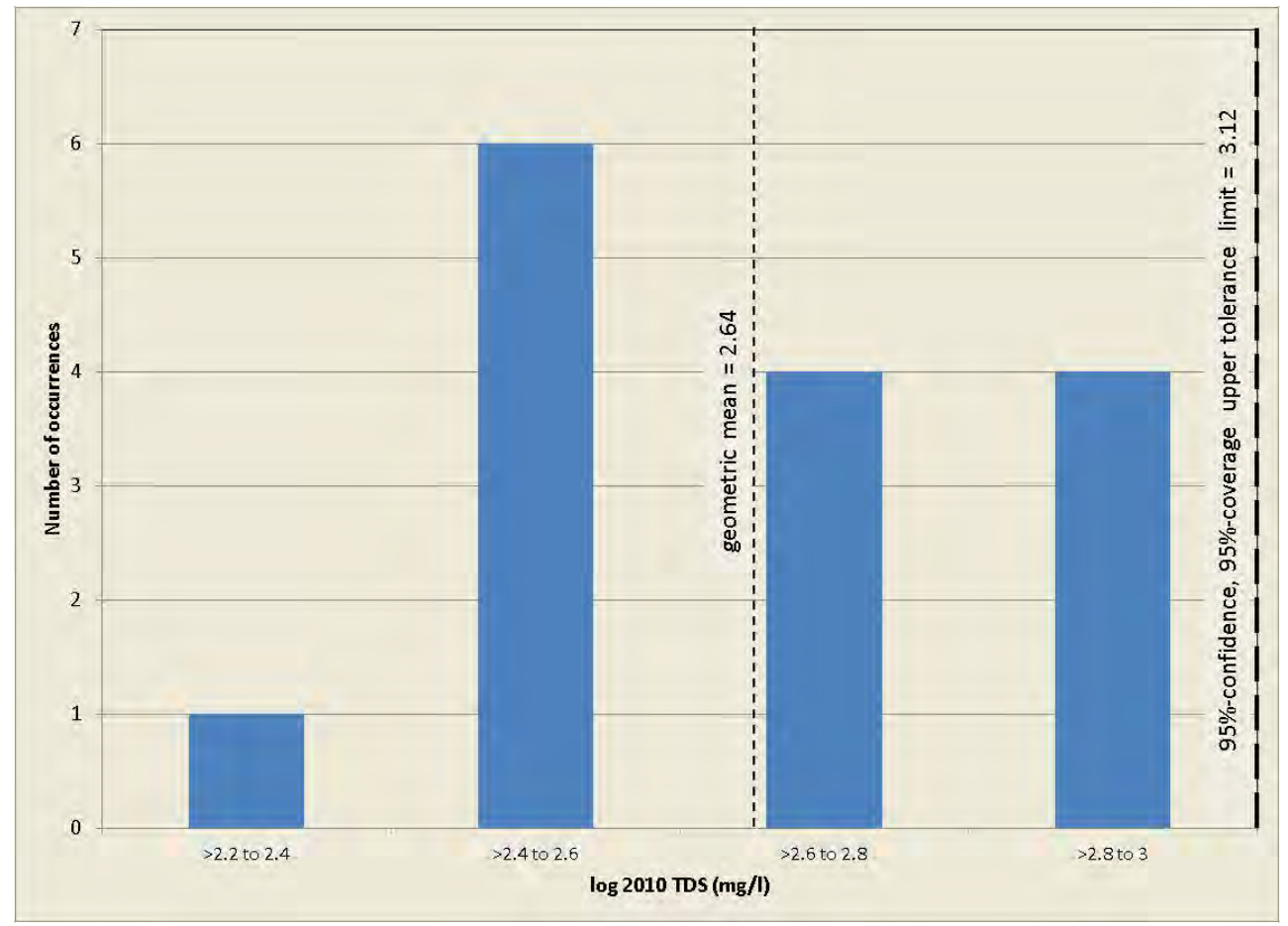

Figure 12. Histogram of select $2010 \log$ TDS from major aquifer study wells. 


\subsubsection{Arsenic}

The 1999 arsenic concentrations are mapped on Figure 13. The values are generally spatially correlated, predominantly in an east-west direction. The 2010 concentrations are plotted on the 1999 contours in Figure 14. While there have been changes in the concentration, most of the values still match the contours or are within one interval. Most of the 1999 values in the vicinity of the model area were nondetect, which was not the case in 2010 due to a lower detection limit. Consequently, a subset of the 2010 data that are not spatially correlated among themselves, as shown in Figure 14, were selected for threshold analysis.

Figure 15 shows the distribution of the log of the selected data. This distribution is consistent with a normal distribution. Consequently, the geometric mean and upper tolerance limit were calculated from the $\log$ of the data.

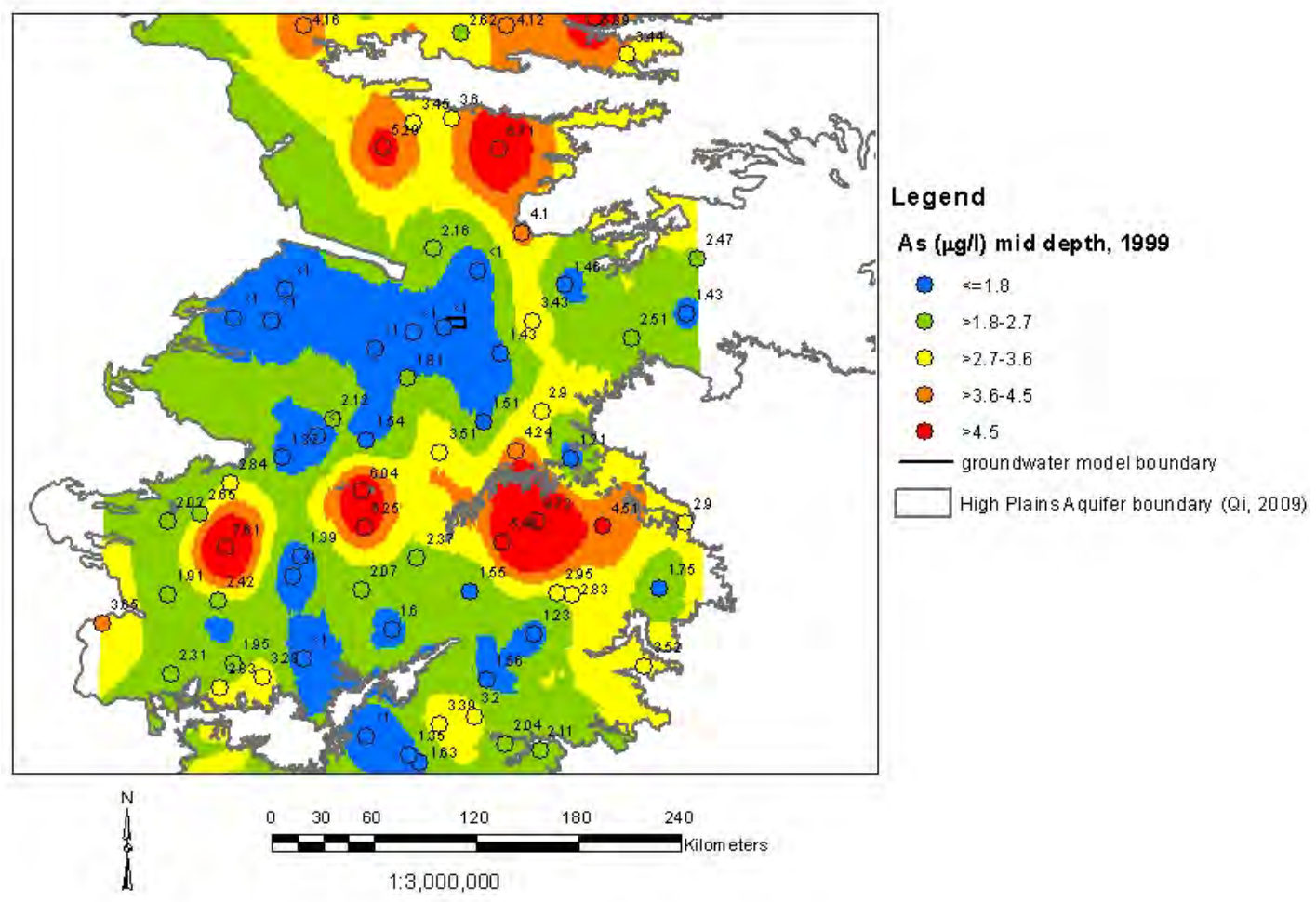

Figure 13. Results for arsenic in 1999 from major aquifer study wells superimposed on contours resulting from kriging with a spherical variogram. 


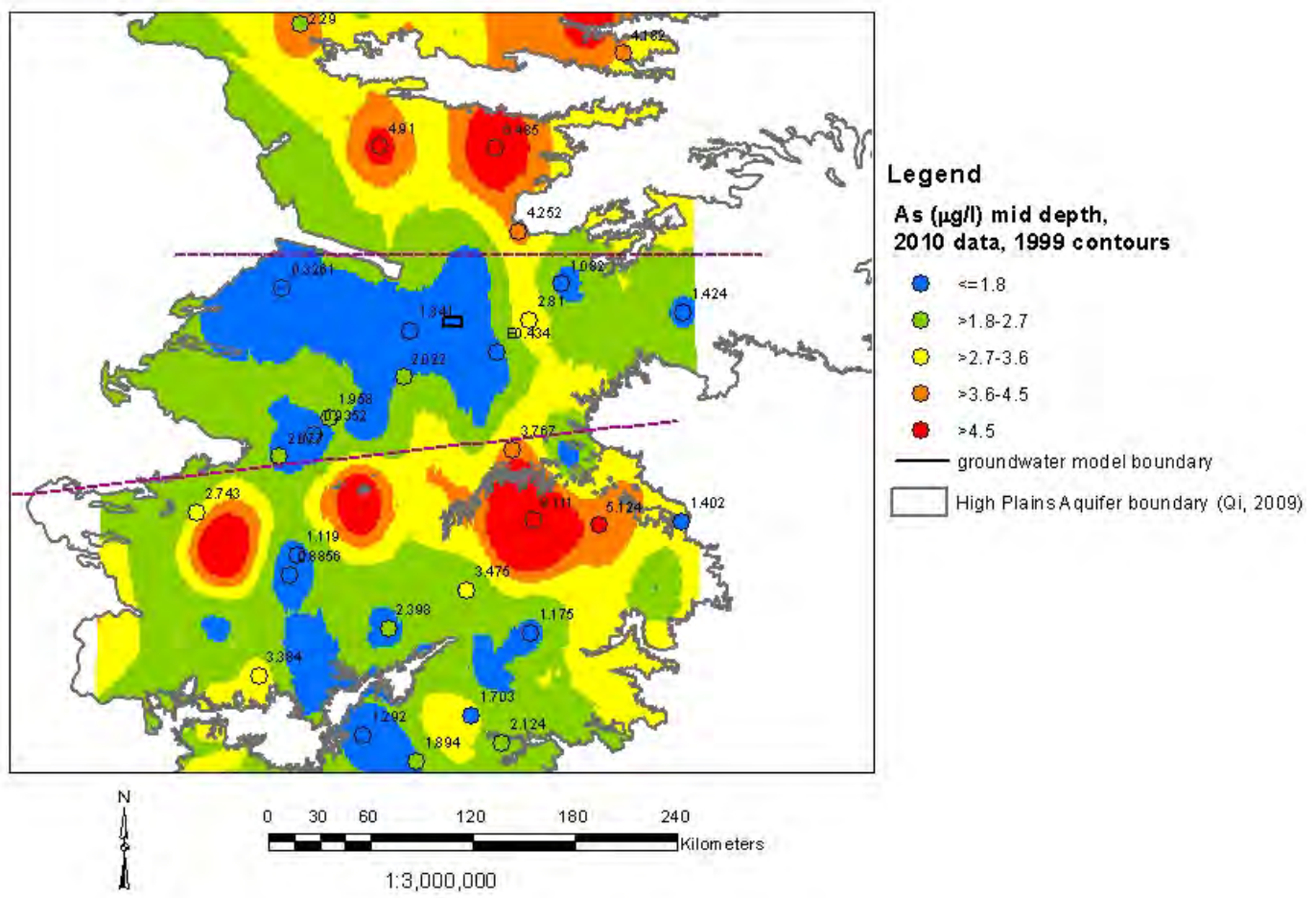

Figure 14. Results for arsenic in 2010 from resampled major aquifer study wells superimposed on contours resulting from kriging 1999 concentrations with a spherical variogram. Values between the purple dashed lines were selected for calculating the threshold.

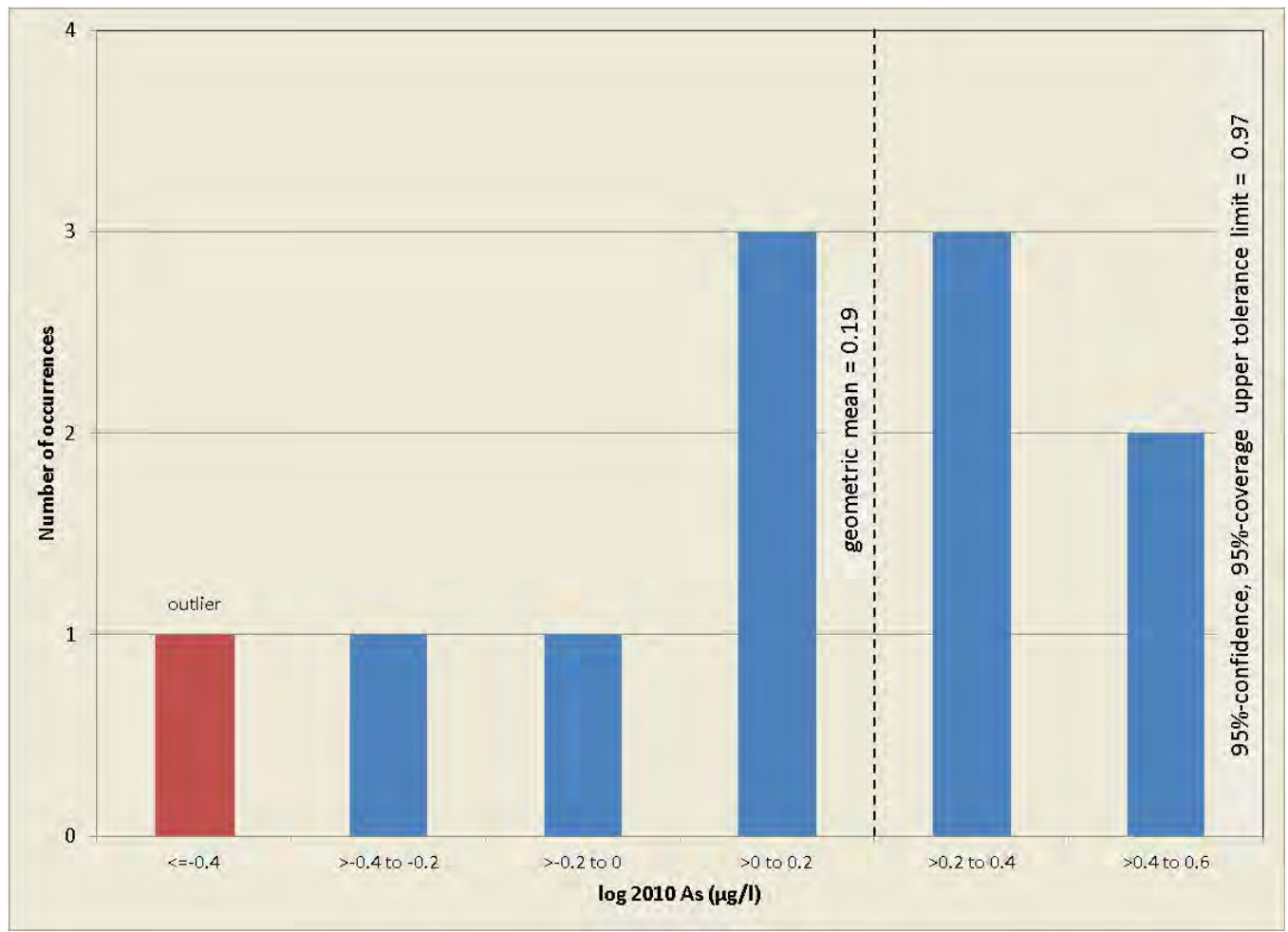

Figure 15. Histogram of select $2010 \log$ arsenic concentrations from major aquifer study wells. 


\subsubsection{Cadmium}

The 2010 cadmium concentrations are mapped on Figure 16. Like TDS, there is a general trend from higher concentrations in the north to lower in the south. Also like TDS, concentrations to the south of the model area are more spatially correlated and more correlated to this trend than are values around the model and to the north. The values in the northern area indicated on Figure 16 were used in threshold development.

One of these results was below the $0.02 \mu \mathrm{g} / 1$ detection limit. Because the approximate quantification limit appears to be less than $0.0114 \mu \mathrm{g} / \mathrm{l}$, this result was assigned a value of $0.005 \mu \mathrm{g} / \mathrm{l}$. Figure 17 shows the distribution of the log of the selected data. The distribution is consistent with a normal distribution. Consequently, the geometric mean and upper tolerance limit were calculated from the log of the data.

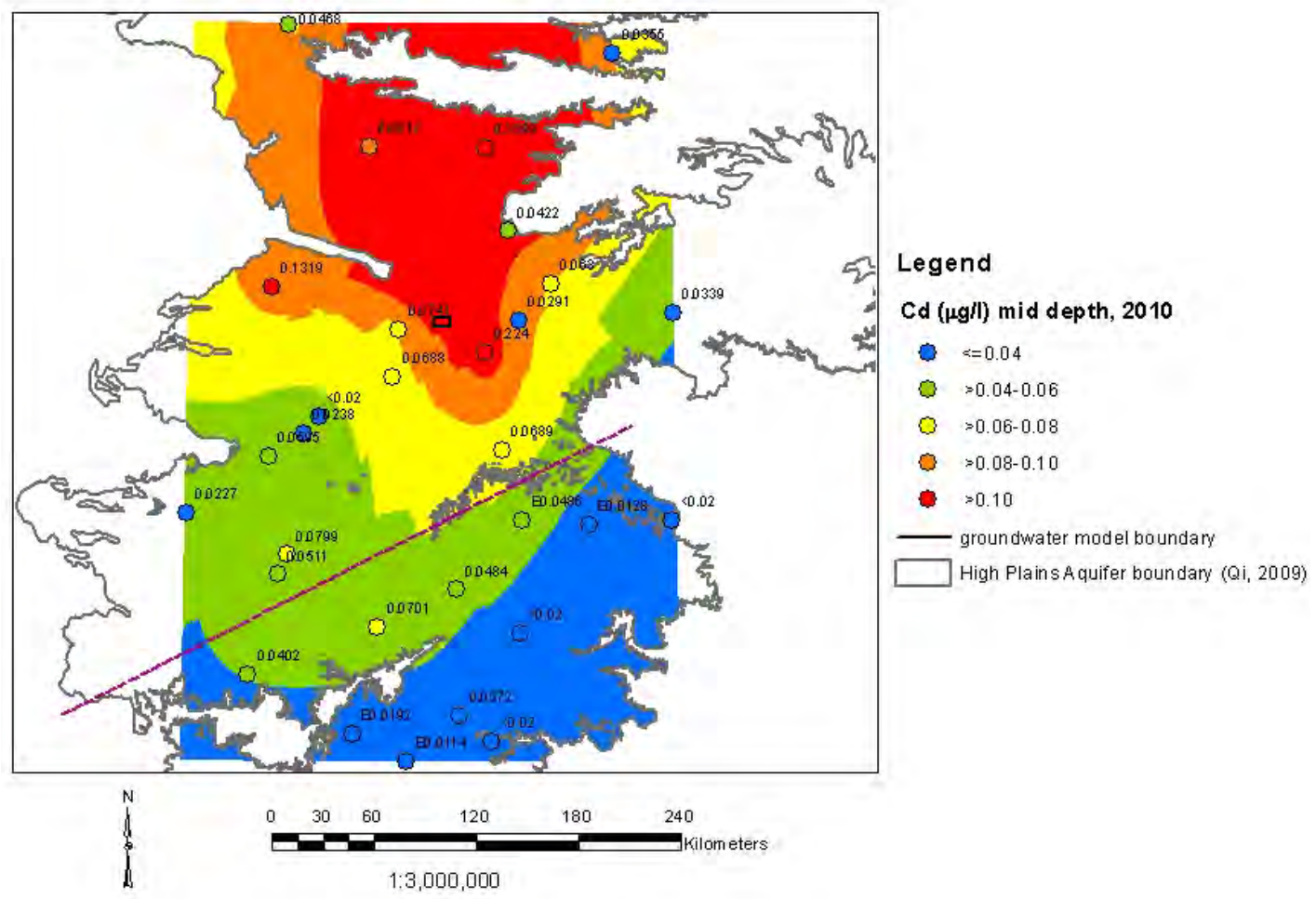

Figure 16. Results for cadmium in 2010 from resampled major aquifer study wells superimposed on contours resulting from kriging with a spherical variogram. Values north of the purple dashed line were used for calculating the threshold. 


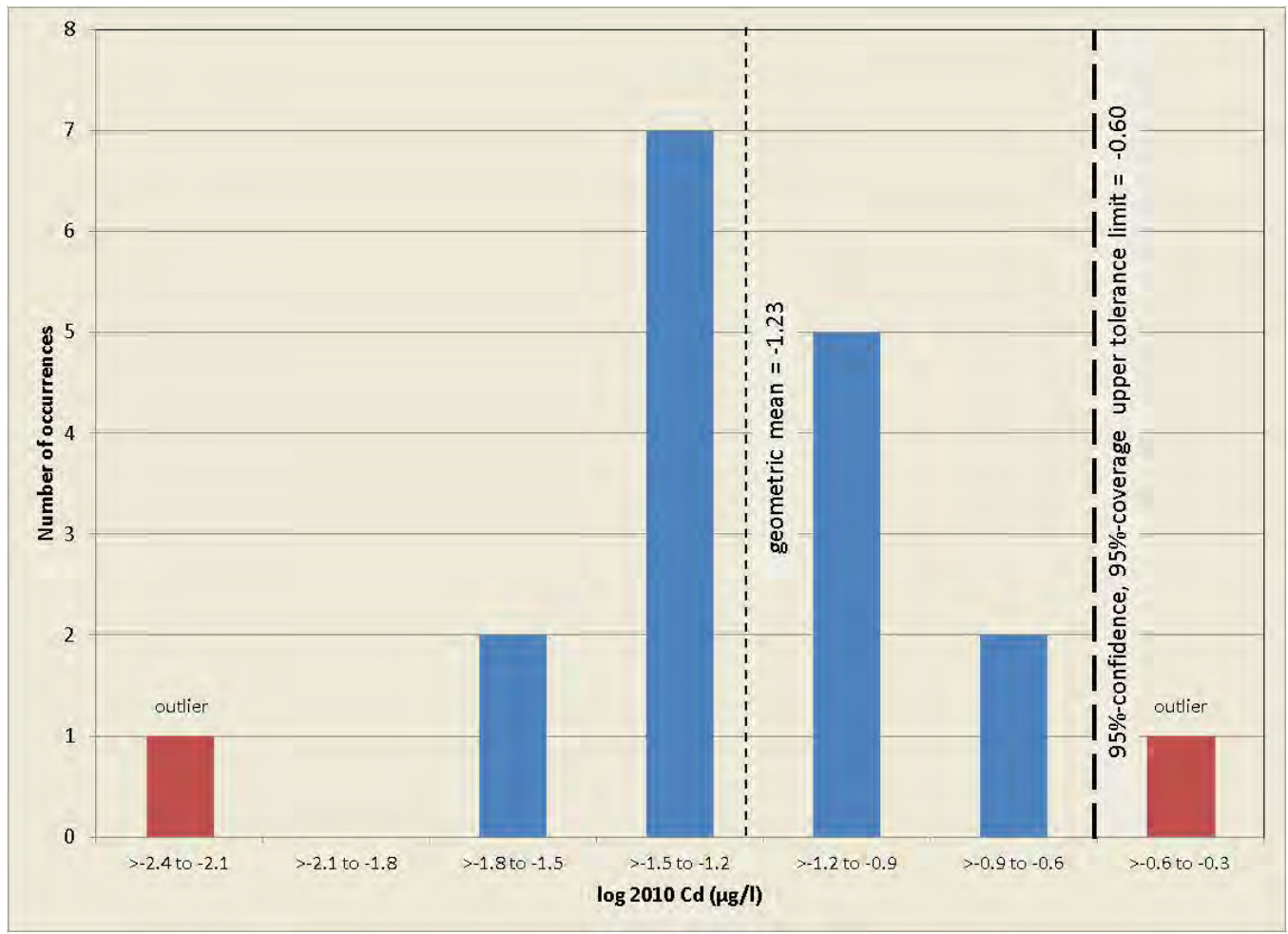

Figure 17. Histogram of select log cadmium concentrations in 2010 from major aquifer study wells.

\subsubsection{Chromium (total)}

The 2010 total chromium concentrations are mapped on Figure 18. Of the 30 results in 2010, 2 were below the detection limit. The detection limit for one was $0.12 \mu \mathrm{g} / 1$. There was one approximately quantified result of $0.985 \mu \mathrm{g} / \mathrm{l}$. Taking this as the approximate quantification limit, the aforementioned nondetect result was assigned a value of about half this limit, $0.05 \mu \mathrm{g} / \mathrm{l}$.

The detection limit for the other nondetect was $1.2 \mu \mathrm{g} / \mathrm{l}$. This same sample had high concentrations of some other inorganic constituents. For instance, the iron and manganese concentrations (567.2 and $924.8 \mu \mathrm{g} / \mathrm{l}$, respectively) were more than an order of magnitude higher than the next highest concentrations. This suggests the higher detection limit for chromium in this sample was due to analytical interference due to the high concentrations of other analytes. In any event, a value of half the detection limit, $0.6 \mu \mathrm{g} / \mathrm{l}$, was assigned to this result.

Figure 18 shows the distribution of concentrations varies spatially. South of the southern purple dashed line, the distribution is bimodal. There is not a single value in the central category in this area. In the north, there is a suggested trend of decreasing concentrations to the north. In particular, the two northernmost results are the second and fourth lowest in the data set given the nondetect assignments. The values between the purple dashed lines on Figure 18 have a more uniform and consistent distribution extending from the model area. Consequently, those values were selected for threshold analysis. 


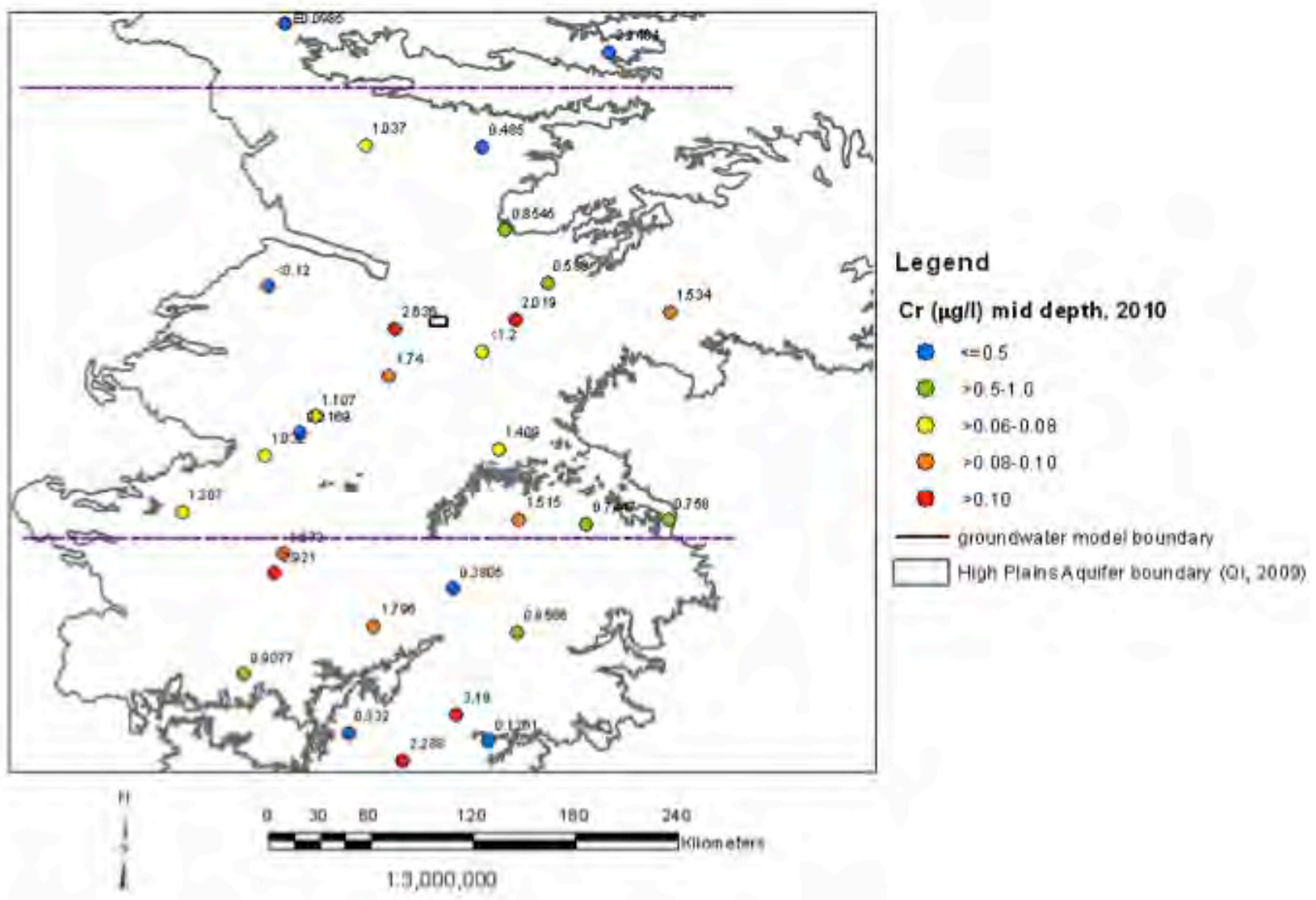

Figure 18. Results for chromium in 2010 from resampled major aquifer study wells. Values between the purple dashed lines were used for calculating the threshold.

Figure 19 shows the distribution of the log of the selected data. The distribution is consistent with a normal distribution. Consequently, the geometric mean and upper tolerance limit were calculated from the $\log$ of the data. 

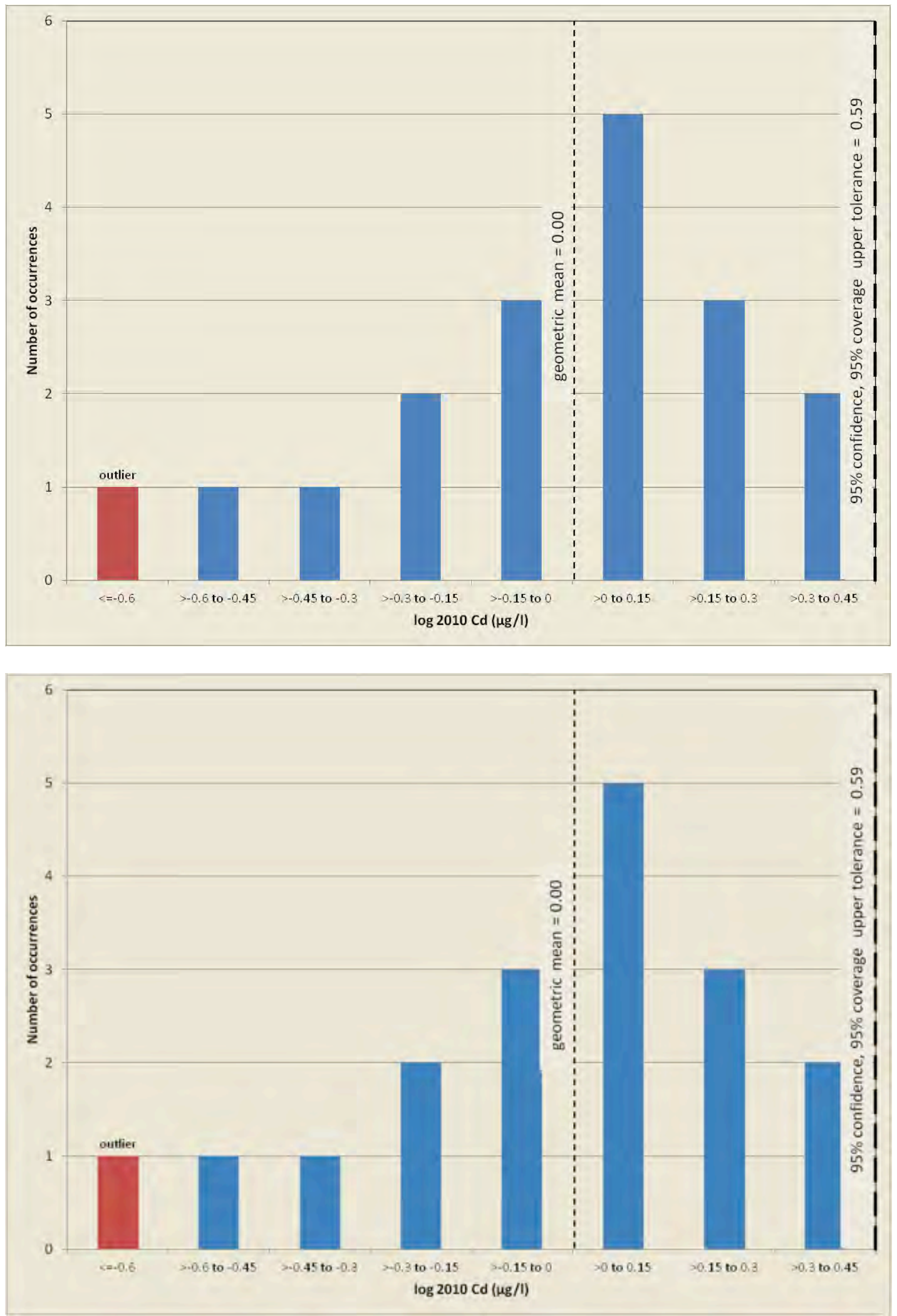

Figure 19. Histogram of log chromium concentrations in 2010 from resampled major aquifer study wells. 


\subsubsection{Lead}

The 2010 lead concentrations are mapped on Figure 20. The values do not appear to be spatially correlated. Of the 30 results in 2010,3 were below the detection limit of $0.03 \mu \mathrm{g} / \mathrm{l}$. These were assigned values half the limit.

Figure 21 shows the distribution of the log of the selected data. The distribution is consistent with a normal distribution. Consequently, the geometric mean and upper tolerance limit were calculated from the $\log$ of the data.

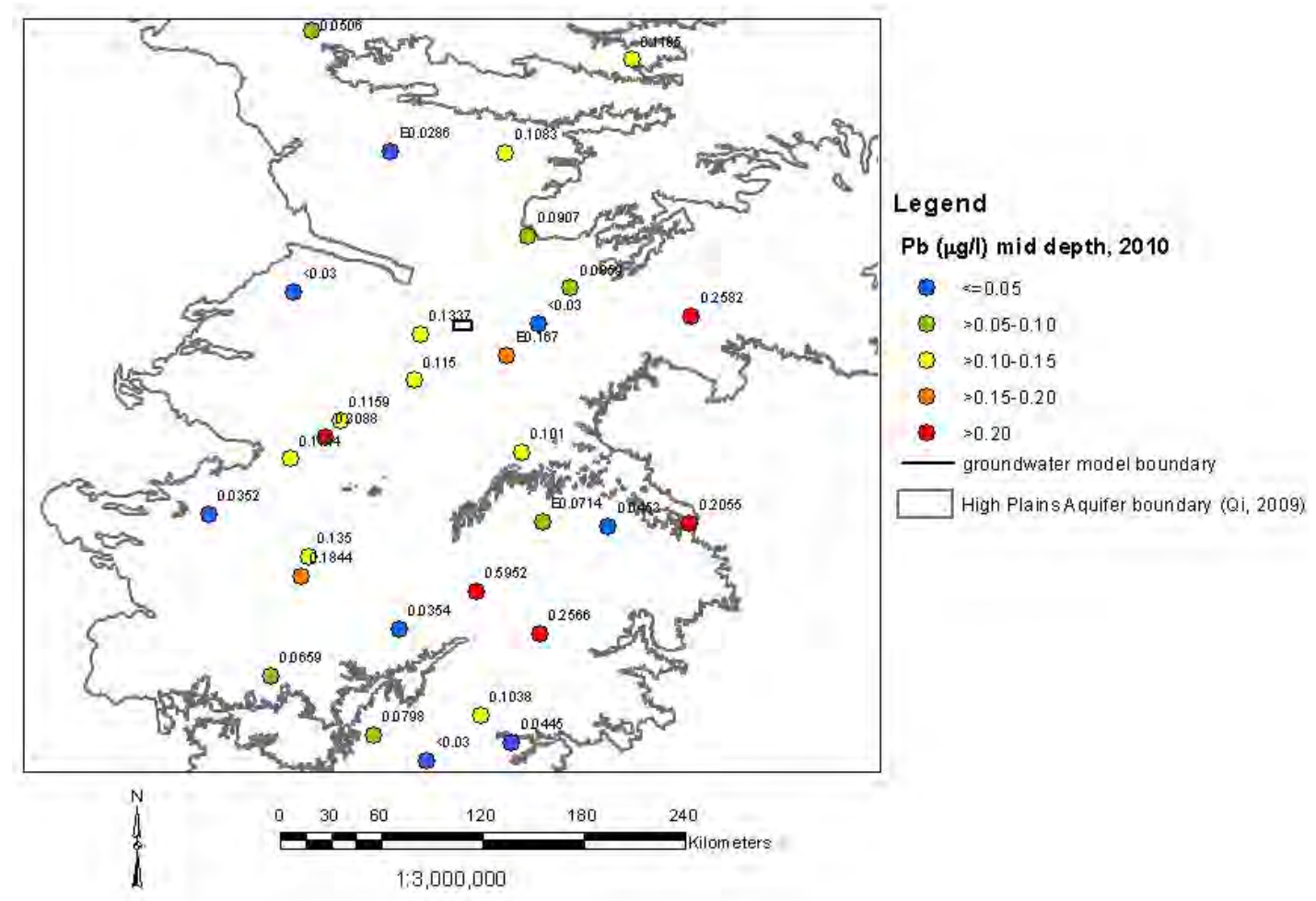

Figure 20. Results for lead in 2010 from resampled major aquifer study wells. 


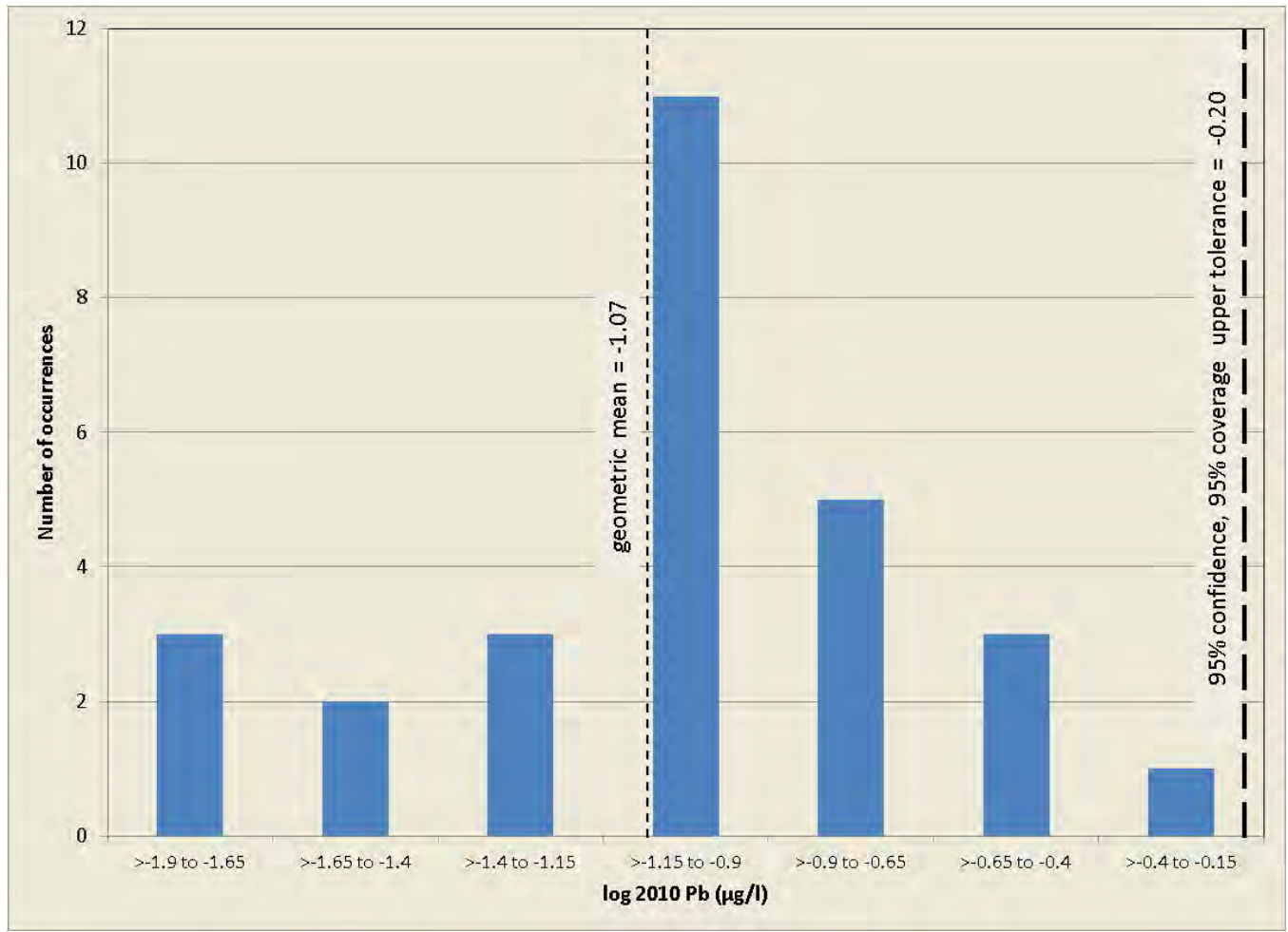

Figure 21. Histogram of log lead concentrations in 2010 from resampled major aquifer study wells.

\subsection{Discussion}

The analyses in this report generally follow the "interwell" approach recommended for determining background groundwater concentrations at sites regulated under the Resource Conservation and Recovery Act of 1976 (EPA 2009). This approach provides a no-impact threshold value for an area of interest based on background groundwater constituent concentrations from wells in a nearby area. This approach requires the mean and variance of the groundwater constituent concentrations in wells across the nearby area to be constant (i.e., stationary) and the same as in the area of interest.

However, the results for several variables in the High Plains Aquifer (e.g., Figure 7, Figure 9, Figure 11, and Figure 16) show significant nonstationarity of the data, with large trends present across the map that indicate the presence of spatial correlation in the data. This is compounded by the relatively small data set from the large regional extent of the Central High Plains region used for this study (e.g., Figure 20). The regional extent of the data covers hundreds of kilometers, more than an order of magnitude larger than the spatial extent of the data set used for the Edwards Aquifer. The presence of this nonstationarity led to an investigation of methods to account for it.

One approach that was investigated was analysis of the change in concentrations between the 1999 and 2010 data sets. Figure 22 shows the distribution of the 2010 arsenic concentration minus the 1999 arsenic concentration. The mean is almost 0 , suggesting no change in overall concentration distribution with time. Mapping the difference indicates little spatial correlation, suggesting the change data might more closely meet the assumption of stationarity of the data. 


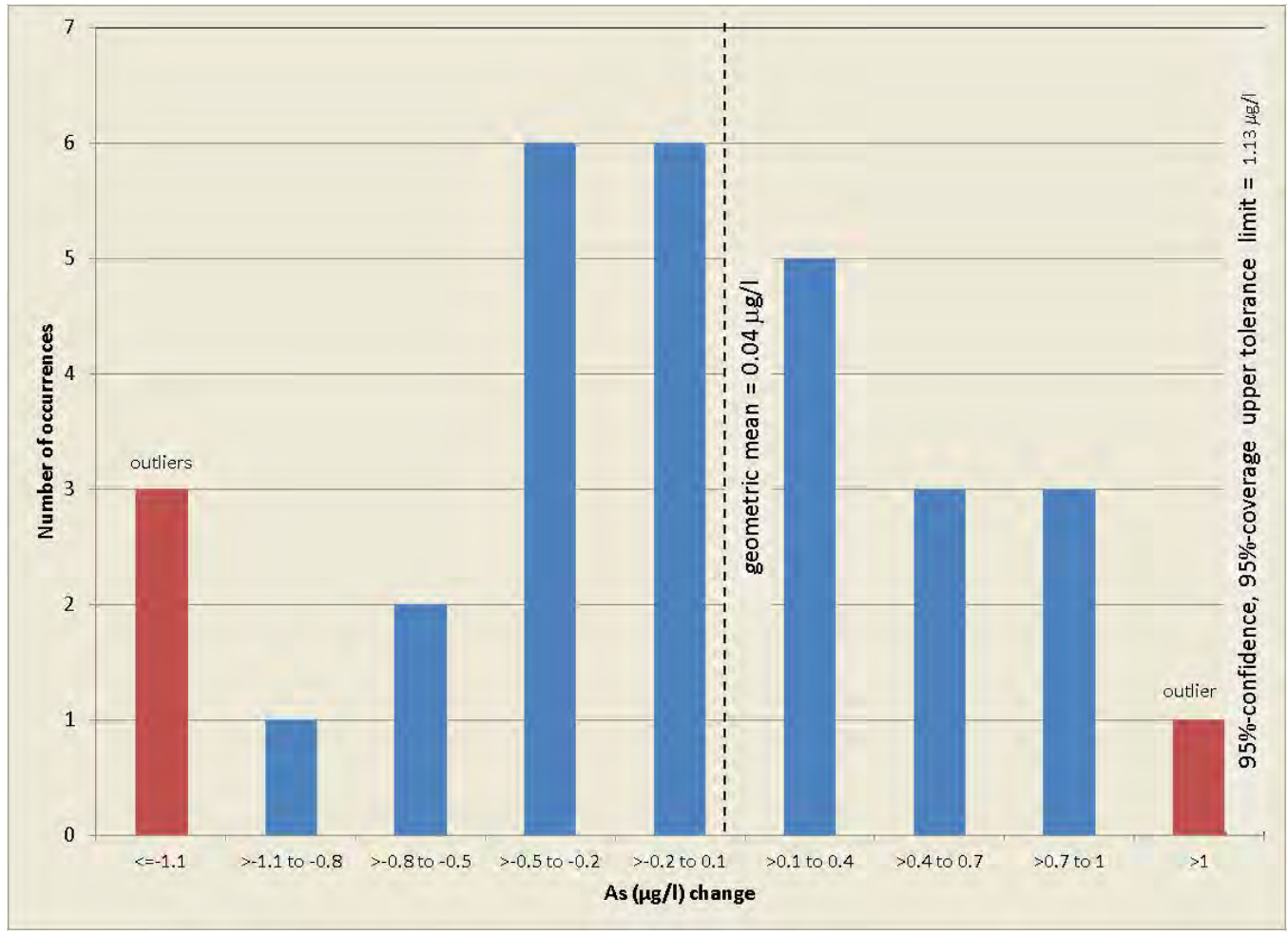

Figure 22. The distribution of 2010 minus 1999 arsenic concentrations at the major aquifer study wells.

Figure 23 and Figure 24 plot the 2010 arsenic data against the 1999 data from the major aquifer study wells. These data do not plot randomly across the range box, but are rather concentrated along the "no change line," which is the locus of unchanging concentrations through time. This indicates arsenic concentrations in the High Plains Aquifer are not temporally independent at an 11-year time interval. Consequently, these data do not comply with the constant mean assumption for the "interwell" approach on the decade time scale. The groundwater at wells with lower concentrations would require more perturbation before triggering the threshold than at wells with higher concentrations.

This suggests an approach that is a hybrid of the interwell and "intrawell" approaches. The intrawell approach sets thresholds based on the sequence of concentrations measured at a specific well through time (EPA 2009). The suggested hybrid approach sets thresholds based on aggregating changes with time from numerous wells. This would allow development of statistics on the temporal distribution of concentration change from a smaller number of sampling events than would be possible with the interwell approach.

The lack of uniformity of the difference in concentration between the upper tolerance limit based on the $\log 2010$ data and the mean concentration at each well is apparent in Figure 24. At the geometric mean, this upper tolerance limit is far in excess of upper tolerance limit at the 11-year time step implied by the upper tolerance limit of the concentration difference.

The difference between the 1999 and 2010 values for TDS and $\mathrm{pH}$ are also normally distributed and show little spatial correlation. Figure 25 and Figure 26 show similar plots for TDS and pH. Figure 25 shows a large difference between the thresholds at the geometric mean resulting from the two approaches 
for TDS. Figure 26 shows the difference for $\mathrm{pH}$ is relatively small at the geometric mean. This difference is in part because the mean difference in $\mathrm{pH}$ from 1999 to 2010 is -0.11 , indicating an overall decline in $\mathrm{pH}$ with time.

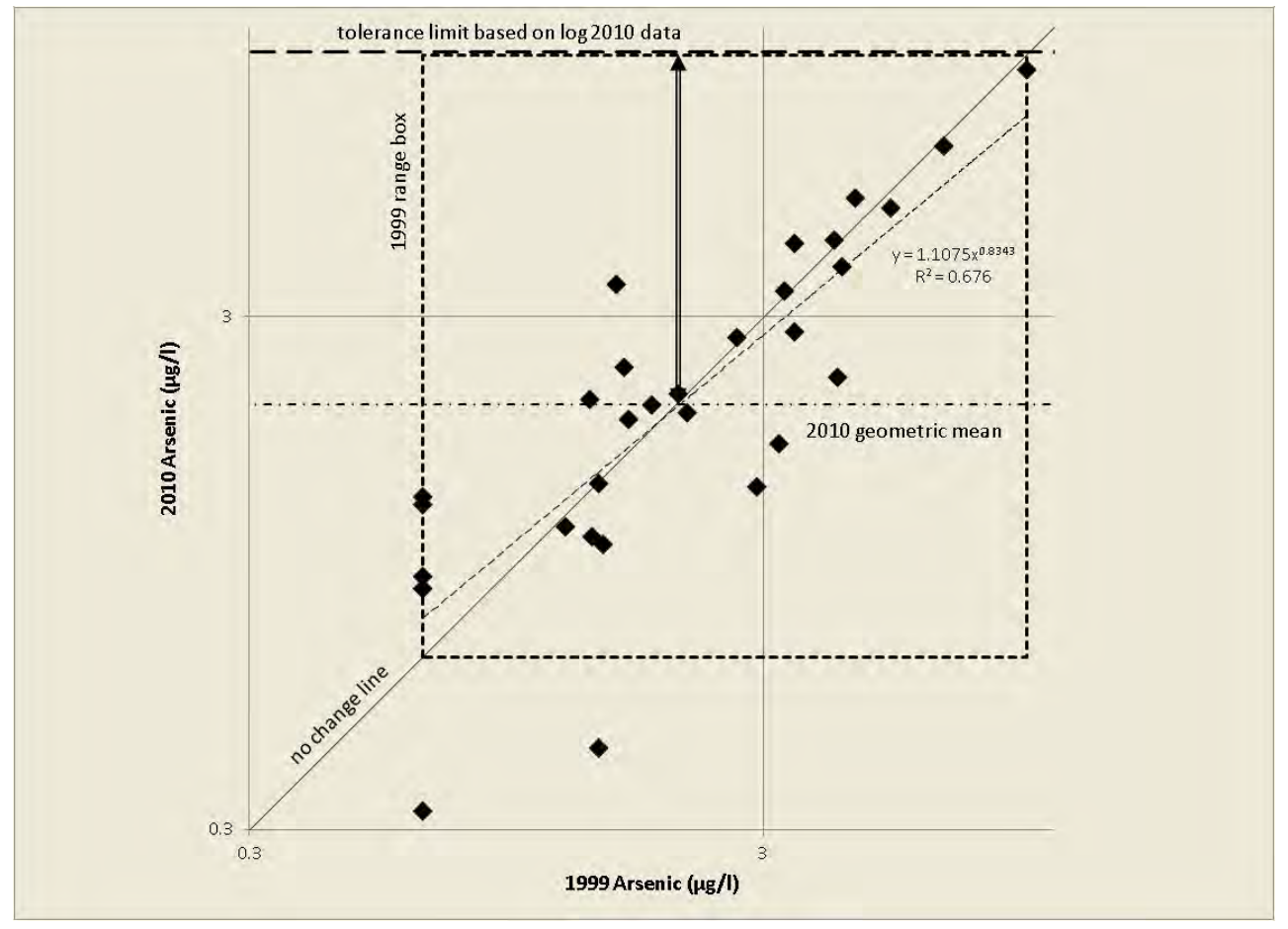

Figure 23. Log-log plot of the 2010 against 1999 arsenic concentrations at the major aquifer study wells.

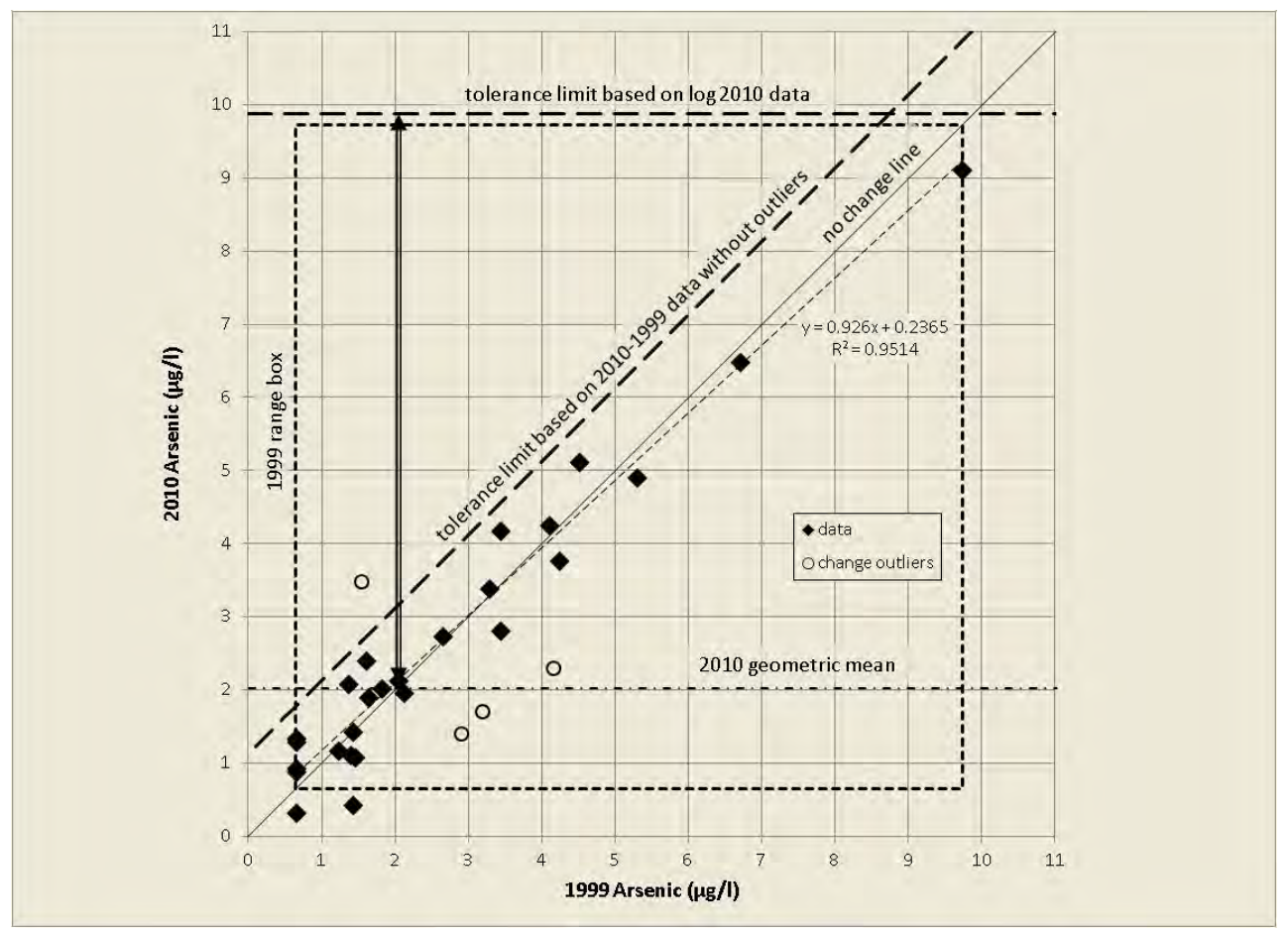

Figure 24. Linear plot of the 2010 against 1999 arsenic concentrations at the major aquifer study wells. 


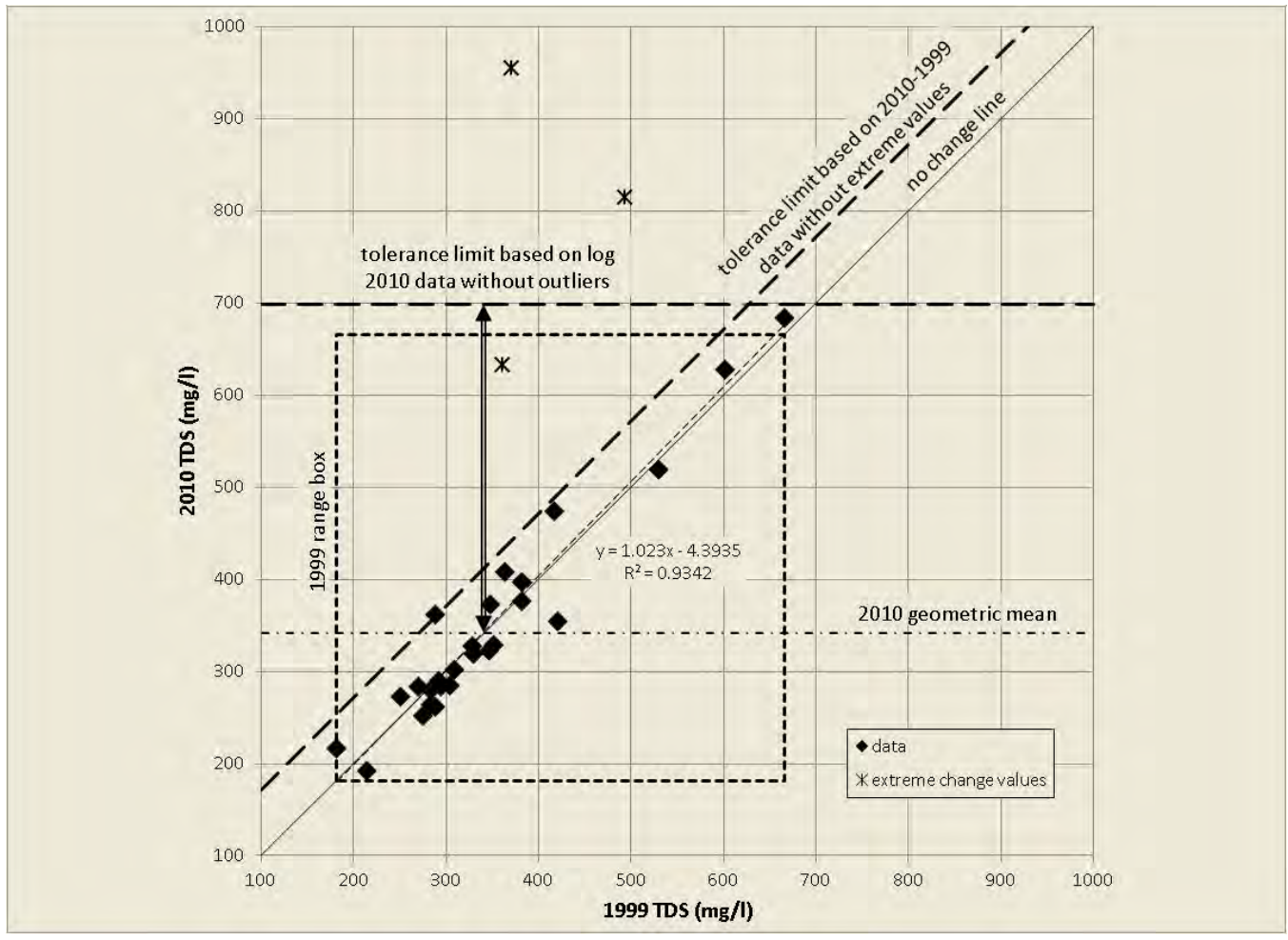

Figure 25. Linear plot of the 2010 against 1999 TDS at the major aquifer study wells.

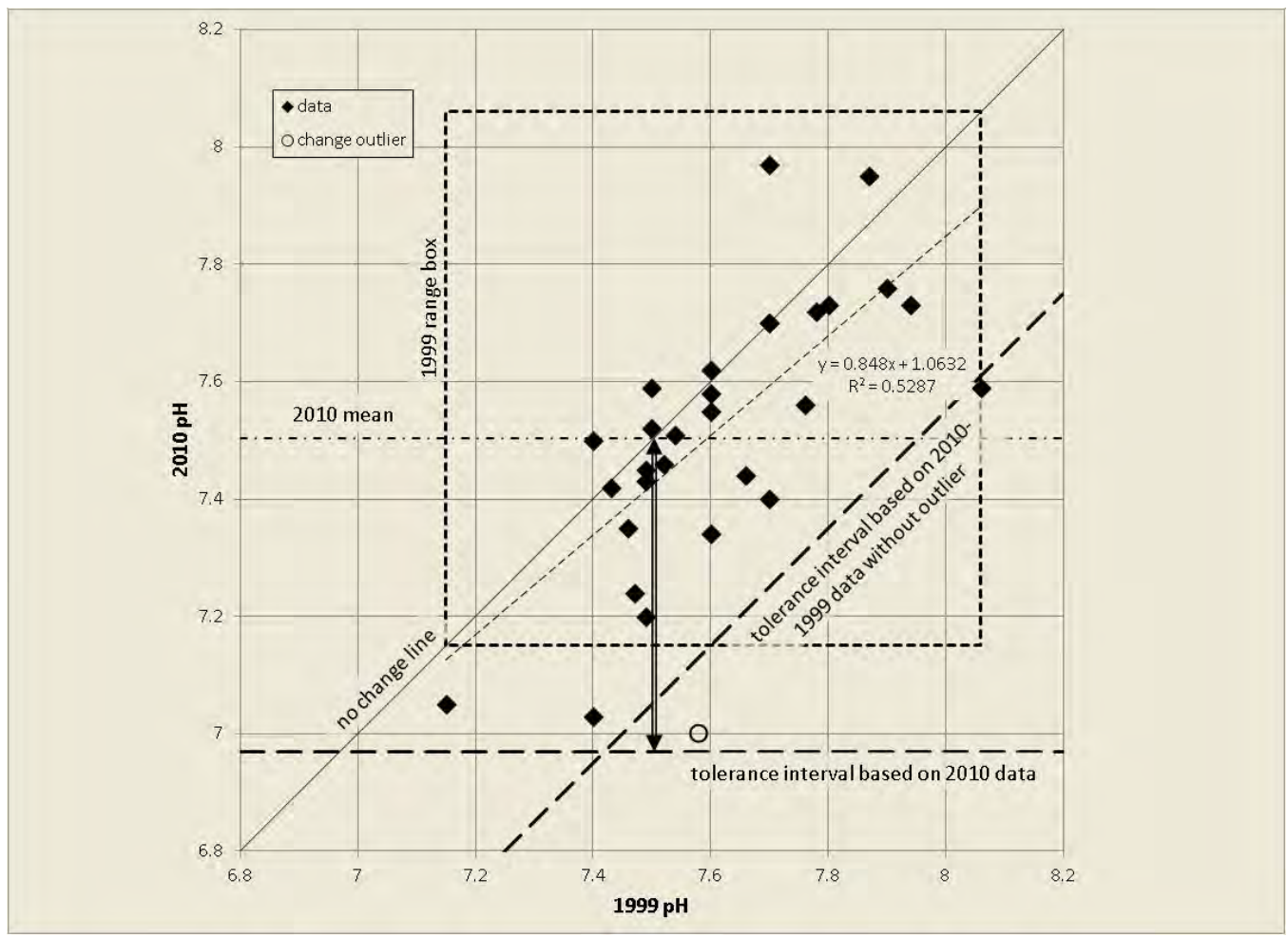

Figure 26. Linear plot of the 2010 against 1999 pH at the major aquifer study wells. 
Differences between the 2010 and 1999 results for chromium could not be calculated for 12 of the 30 results because of nondetections in 1999 ( 2 locations which also were nondetect in 2010). The difference between 16 of the other 18 pairs was negative. For the 10 sites with nondetects in 1999 and detects in 2010, all but 1 of the 2010 results was less than the 1999 detection limit. The distribution of these 2010 results does not suggest a predominance of positive differences is likely if the 1999 results had been quantified.

The distribution of available chromium differences indicates the 2010 results were less on average than the 1999 results, with a mean and median decrease of 0.29 and $0.20 \mu \mathrm{g} / 1$, respectively. Whether this was due to changes in the aquifer or analytical changes is not known.

The same analysis could not be carried out for cadmium and lead concentrations because all and almost all the concentrations were below detection in 1999, respectively. This could be a problem with a change-based approach, as pairs of data separated by a common time step would be needed, and this is often unavailable.

Given the 11-year time step, the hybrid approach will tend to give false positives and the interwell approach described in this report will tend to give false negatives. The hybrid approach also appears to be more spatially independent, but it is likely time dependent as the distribution of the difference in parameter values over time is time dependent. For example, the range of the difference in parameter values over time likely increases as the time step increases until the difference approaches time independence. Consequently, the hybrid approach described here can only be used when the time steps at the monitoring point of interest match time steps in the available background data.

The interwell approach is the available option when there is a question if a previously unmonitored point has been impacted by leakage. This is a likely scenario at storage sites and has been recommended here for assessing the model results. The hybrid approach is an option for judging if the results from monitoring points have crossed thresholds after a few to several sampling events, at which time the data may be insufficient for the intrawell approach to provide a robust result but be sufficient to judge if the assumptions of the interwell approach hold. Such monitoring points might be implemented adjacent to deep wells or along faults of concern for leakage.

More research into the hybrid approach described in this report is needed to develop a better understanding of the change in range, and perhaps type of distribution, of the parameter differences with different length time steps. A goal of this research would be modeling the range change through time with empirical equations, which would make this method more robust and useful.

An additional approach that should be investigated in the future would be use of a non-uniform starting value and the use of an alternative "intrawell" approach for identification of cells that exhibit significant changes in concentrations over time. This approach would only be suitable for study areas where spatial heterogeneity of the input data was found to be significant, e.g., through the use of ANOVA (EPA 2009) or geostatistical methods. Then, if there were sufficient data available to map the concentration of the contaminant across the study area, a heterogeneous starting concentration could be developed. During the modeling runs, local backgrounds would be provided by the time series of concentrations at each cell prior to the time that injection of $\mathrm{CO}_{2}$ begins. Continued monitoring of the time series of concentrations at each cell after injection begins would allow identification of cells where a significant increase occurred, possibly using an approach similar to the Shewhart-CUSUM control chart 
method described in the EPA Unified Guidance (EPA 2009). This procedure would be analogous to one of the main intrawell testing procedures described in EPA (2009), and recommended when spatial heterogeneity indicates that the interwell comparison approach is not suitable.

\subsection{Conclusions}

Initial efforts to develop no-impact threshold values for the urban shallow-unconfined Edwards Aquifer and the High Plains Aquifer demonstrate potential methodologies and statistical protocols for determining statistically significant changes between background concentrations and concentrations predicted by Gen II models. Threshold values were determined based on an interwell approach for determining background groundwater concentrations as recommended in the EPA's Unified Guidance for Statistical Analysis of Groundwater Monitoring Data at RCRA Facilities (EPA 2009). These no-impact threshold values could be used instead of drinking water limits (e.g., MCLs) to inform a "no change" scenario with respect to groundwater impacts. They are intended for use in helping to predict areas of potential impact. They are not intended for use as alternate regulatory limits.

Development of "generic" threshold values that could be used for a number of model domains appears unlikely. Instead, the threshold values must be based on site-specific groundwater quality data. The scarcity of existing data, proximity of the data to the target model domain, potential spatial heterogeneity, and temporal trends make development of "clean" statistically robust data sets and use of valid statistical assumptions, challenging. As seen with High Plains Aquifer TDS, calculated no-impact threshold values based on the $95 \%$-confidence and $95 \%$-coverage tolerance limits, can in some cases exceed regulatory standards. Other approaches, such as the hybrid intrawell-interwell approach or the use of control charts to monitor the time series of concentrations at each cell, may provide other mechanisms for calculating no-impact threshold limits.

\subsection{References}

Bacon DH. 2012. Reduced Order Model for the Geochemical Impacts of Carbon Dioxide, Brine and Trace Metal Leakage into an Unconfined, Oxidizing Carbonate Aquifer, Version 2.0. PNNL-22049 (Limited Distribution), Pacific Northwest National Laboratory, Richland, Washington.

Bacon DH, Z Dai, E Keating, and H Viswanathan. 2012. "Development of a Reduced-Order Model of the Geochemical Impacts of $\mathrm{CO}_{2}$ and Brine Leakage into an Unconfined Limestone Aquifer." Presented by DH Bacon at the 11th Annual Conference on Carbon Capture Utilization \& Sequestration, Pittsburgh, Pennsylvania, on May 2, 2012. PNNL-SA-87348.

Davis J. 2002. Statistics and Data Analysis in Geology. 3rd ed., John Wiley \& Sons, Inc., New York.

Dai Z, E Keating, and $\mathrm{H}$ Viswanathan. 2011. Impact of the Leaked $\mathrm{CO}_{2}$ from Deep Reservoirs on Quality of Shallow Groundwater. 2011 NRAP progress report, Los Alamos National Laboratory, New Mexico. 
EPA - U.S. Environmental Protection Agency. 2009. Statistical Analysis of Groundwater Monitoring Data at RCRA Facilities, Unified Guidance. EPA 530/R-09-007, Washington, D.C. Available at http://www.epa.gov/epa waste/hazard/correctiveaction/resources/guidance/sitechar/ gwstats/index.htm.

Gurdak JJ, PB McMahon, KF Dennehy, and SL Qi. 2009. "Water Quality in the High Plains Aquifer, Colorado, Kansas, Nebraska, New Mexico, Oklahoma, South Dakota, Texas, and Wyoming, 1999-2004." U.S. Geological Survey Circular 1337, 63 pp.

Helsel DR. 2012. Statistics for Censored Environmental Data Using Minitab and R. 2nd edition, John Wiley \& Sons, Inc., New York.

Lee Lopaka. 2012. NADA: Nondetects and Data Analysis for Environmental Data. R package version 1.5-4. Available at http://CRAN.R-project.org/package=NADA.

Mansoor K, Y Sun, ED Jones, WJ Trainor-Guitton, and SA Carroll. 2012. "Assessing Impact of $\mathrm{CO}_{2}$ Leakage in Groundwater Aquifers in the Presence of Data Uncertainties." XIX International Conference on Computational Methods in Water Resources, June 17-21, 2012, University of Illinois at UrbanaChampaign, Urbana, Illinois.

McMahon PB. 2001. Vertical Gradients in Water Chemistry in the Central High Plains Aquifer, Southwestern Kansas and Oklahoma Panhandle, 1999. USGS Water-Resources Investigations Report 01-4028, 47 pp.

McMahon PB, KF Dennehy, BW Bruce, JJ Gurdak, and SL Qi. 2007. Water-Quality Assessment of the High Plains Aquifer, 1999-2004. U.S. Geological Survey Professional Paper 1749, 136 pp.

Musgrove M, L Fahlquist, NA Houston, RJ Lindgren, and PB Ging. 2010. Geochemical Evolution Processes and Water-Quality Observations Based on Results of the National Water-Quality Assessment Program in the San Antonio Segment of the Edwards Aquifer, 1996-2006. U.S. Geological Survey Scientific Investigations Report 2010-5129, 93 pp. Appendixes available online at http://pubs.usgs.gov/sir/2010/5129/.

National Institute of Standards/SEMATECH. 2012. e-Handbook of Statistical Methods. Accessed December 13, 2012, at http://www.itl.nist.gov/div898/handbook/.

R Development Core Team. 2012. R: A Language and Environment for Statistical Computing. R Foundation for Statistical Computing, Vienna, Austria. ISBN 3-900051-07-0, available at http://www.R-project.org.

Resource Conservation and Recovery Act of 1976. 1976. Public Law 94-580, as amended, 42 USC 6901 et seq. and 42 USC 6927(c) et seq.

USGS - U.S. Geological Survey. 1990-2000. “Ground Water Atlas of the United States.” Accessed December 13, 2012, at http://pubs.usgs.gov/ha/ha730/. 
Whittemore DO, ER Grieve, DP Young, and BB Wilson. 2005. Water Quality in the High Plains Aquifer and the Cimarron River in Seward and Meade Counties, Kansas; Part of Data, Research, and Technical Support for Ogallala-High Plains Aquifer Assessment, Planning, and Management - Kansas Water Plan - FY 2005. Kansas Geological Survey Open File Report 2005-27.

Young DS. 2010. “Tolerance: An R Package for Estimating Tolerance Intervals." Journal of Statistical Software 36(5):1-39. Accessed December 13, 2012, at http://www.jstatsoft.org/v36/i05/. 


\section{Appendix A}

\section{Data from the Shallow Urban Unconfined Edwards Aquifer Used for Analysis of Metals Concentrations}



Table A.1. Data from the shallow urban unconfined Edwards Aquifer used for analysis of metals concentrations.

\begin{tabular}{|c|c|c|c|c|c|c|c|c|c|}
\hline USGS_ID & USGS_ID_Cen & $\begin{array}{l}\text { Sample_date } \\
\text { (yyyymmdd) }\end{array}$ & Sample_date_Cen & $\begin{array}{c}\text { Arsenic } \\
(\mu \mathrm{g} / \mathrm{L}\end{array}$ & AsCen & $\begin{array}{c}\text { Lead } \\
(\mu \mathrm{g} / \mathrm{L}) \\
\end{array}$ & LeadCen & Ln_Lead & Ln_LeadCen \\
\hline 293404098382001 & False & 20010604 & False & 0.28 & False & 0.08 & True & -2.52573 & True \\
\hline 293436098343001 & False & 20010605 & False & 0.34 & False & 0.08 & True & -2.52573 & True \\
\hline 293516098325501 & False & 20010605 & False & 0.35 & False & 0.08 & True & -2.52573 & True \\
\hline 293535098304101 & False & 20010606 & False & 0.24 & False & 0.14 & False & -1.9951 & False \\
\hline 293436098343001 & False & 20021119 & False & 0.46 & False & 0.08 & True & -2.52573 & True \\
\hline 293516098325501 & False & 20021120 & False & 0.47 & False & 0.05 & False & -2.99573 & False \\
\hline 293404098382001 & False & 20021203 & False & 0.37 & False & 0.08 & True & -2.52573 & True \\
\hline 293643098264001 & False & 20021204 & False & 0.34 & False & 0.05 & False & -2.99573 & False \\
\hline 293535098304101 & False & 20021205 & False & 0.26 & False & 0.08 & True & -2.52573 & True \\
\hline 293643098264001 & False & 20041202 & False & 0.3 & False & 0.08 & True & -2.52573 & True \\
\hline 293535098304101 & False & 20041203 & False & 0.37 & False & 0.08 & True & -2.52573 & True \\
\hline 293404098382001 & False & 20041203 & False & 0.4 & False & 0.08 & True & -2.52573 & True \\
\hline 293436098343001 & False & 20041209 & False & 0.38 & False & 0.08 & True & -2.52573 & True \\
\hline 293516098325501 & False & 20041209 & False & 0.52 & False & 0.08 & True & -2.52573 & True \\
\hline 293520098254101 & False & 20060816 & False & 0.29 & False & 0.08 & True & -2.52573 & True \\
\hline 293615098262301 & False & 20060817 & False & 0.18 & False & 0.08 & True & -2.52573 & True \\
\hline 293537098262401 & False & 20060817 & False & 0.29 & False & 0.08 & True & -2.52573 & True \\
\hline 293504098270901 & False & 20060818 & False & 0.27 & False & 0.08 & True & -2.52573 & True \\
\hline 293528098274301 & False & 20060821 & False & 0.24 & False & 0.11 & False & -2.20727 & False \\
\hline 293456098280201 & False & 20060821 & False & 0.29 & False & 0.15 & False & -1.89712 & False \\
\hline 293643098264001 & False & 20060822 & False & 0.22 & False & 0.05 & False & -2.99573 & False \\
\hline 293746098265401 & False & 20060822 & False & 0.31 & False & 0.05 & False & -2.99573 & False \\
\hline 293559098284801 & False & 20060823 & False & 0.19 & False & 0.08 & True & -2.52573 & True \\
\hline 293534098282801 & False & 20060823 & False & 0.31 & False & 0.08 & True & -2.52573 & True \\
\hline 293516098325501 & False & 20060824 & False & 0.46 & False & 0.08 & True & -2.52573 & True \\
\hline 293439098324101 & False & 20060824 & False & 0.46 & False & 0.08 & True & -2.52573 & True \\
\hline 293611098311901 & False & 20060828 & False & 0.27 & False & 0.08 & True & -2.52573 & True \\
\hline 293408098331301 & False & 20060829 & False & 0.27 & False & 0.05 & False & -2.99573 & False \\
\hline 293459098321401 & False & 20060829 & False & 0.28 & False & 0.07 & False & -2.65926 & False \\
\hline 293348098334101 & False & 20060830 & False & 0.28 & False & 0.06 & False & -2.81341 & False \\
\hline
\end{tabular}


Table A.1. (contd)

\begin{tabular}{|c|c|c|c|c|c|c|c|c|c|}
\hline USGS_ID & USGS_ID_Cen & $\begin{array}{l}\text { Sample_date } \\
\text { (yyyymmdd) }\end{array}$ & Sample_date_Cen & $\begin{array}{c}\text { Arsenic } \\
(\mu \mathrm{g} / \mathrm{L}\end{array}$ & AsCen & $\begin{array}{c}\text { Lead } \\
(\mu \mathrm{g} / \mathrm{L})\end{array}$ & LeadCen & Ln_Lead & Ln_LeadCen \\
\hline 293340098344701 & False & 20060830 & False & 0.3 & False & 0.05 & False & -2.99573 & False \\
\hline 293535098304101 & False & 20060831 & False & 0.17 & False & 0.09 & False & -2.40795 & False \\
\hline 293436098343001 & False & 20060831 & False & 0.34 & False & 0.06 & False & -2.81341 & False \\
\hline 293359098405401 & False & 20060901 & False & 0.27 & False & 0.12 & False & -2.12026 & False \\
\hline 293405098394201 & False & 20060905 & False & 0.23 & False & 0.12 & False & -2.12026 & False \\
\hline 293404098382001 & False & 20060905 & False & 0.31 & False & 0.12 & False & -2.12026 & False \\
\hline 293429098373801 & False & 20060906 & False & 0.3 & False & 0.09 & False & -2.40795 & False \\
\hline 293350098355801 & False & 20060906 & False & 0.37 & False & 0.08 & False & -2.52573 & False \\
\hline 293508098375101 & False & 20060907 & False & 0.29 & False & 0.06 & False & -2.81341 & False \\
\hline 293516098362801 & False & 20060907 & False & 0.33 & False & 0.09 & False & -2.40795 & False \\
\hline 293635098302301 & False & 20060908 & False & 0.33 & False & 0.08 & False & -2.52573 & False \\
\hline 293252098380801 & False & 20060911 & False & 0.4 & False & 0.1 & False & -2.30259 & False \\
\hline 293425098350801 & False & 20060911 & False & 0.42 & False & 0.08 & False & -2.52573 & False \\
\hline 293530098343401 & False & 20060912 & False & 0.49 & False & 0.11 & False & -2.20727 & False \\
\hline 293535098304101 & False & 20061213 & False & 0.21 & False & 0.12 & True & -2.12026 & True \\
\hline 293643098264001 & False & 20061213 & False & 0.24 & False & 0.12 & True & -2.12026 & True \\
\hline 293404098382001 & False & 20061218 & False & 0.31 & False & 0.12 & True & -2.12026 & True \\
\hline 293436098343001 & False & 20061219 & False & 0.4 & False & 0.12 & True & -2.12026 & True \\
\hline 293516098325501 & False & 20061219 & False & 0.52 & False & 0.12 & True & -2.12026 & True \\
\hline
\end{tabular}




\section{Appendix B}

\section{Data from the Shallow Urban Unconfined Edwards Aquifer Used for Analysis of $\mathrm{pH}$ and TDS Concentrations}





\section{Appendix B}

\section{Data from the Shallow Urban Unconfined Edwards Aquifer Used for Analysis of $\mathrm{pH}$ and TDS Concentrations}

Table B.1. Data from the shallow urban unconfined Edwards Aquifer used for analysis of $\mathrm{pH}$ and TDS concentrations.

\begin{tabular}{|c|c|c|c|c|}
\hline $\begin{array}{l}\text { State Well } \\
\text { Number }\end{array}$ & $\begin{array}{c}\text { USGS } \\
\text { Identification } \\
\text { Number }\end{array}$ & $\begin{array}{l}\text { Sample Date } \\
\text { (yyyymmdd) }\end{array}$ & $\mathrm{pH}$ & TDS (mgL) \\
\hline AY-68-27-610 & 293252098380801 & 20060911 & 6.8 & 337 \\
\hline AY-68-27-610 & 293252098380801 & 19981210 & 6.9 & 319 \\
\hline AY-68-28-516 & 293340098344701 & 20060830 & 6.8 & 362 \\
\hline AY-68-28-516 & 293340098344701 & 19981208 & 6.9 & 344 \\
\hline AY-68-28-515 & 293348098334101 & 20060830 & 7 & 320 \\
\hline AY-68-28-515 & 293348098334101 & 19981106 & 6.9 & 312 \\
\hline AY-68-28-406 & 293350098355801 & 20060906 & 6.9 & 331 \\
\hline AY-68-28-406 & 293350098355801 & 19981106 & 6.9 & 364 \\
\hline AY-68-27-517 & 293359098405401 & 20060901 & 6.9 & 347 \\
\hline AY-68-27-517 & 293359098405401 & 19981110 & 6.8 & 361 \\
\hline AY-68-27-612 & 293404098382001 & 20061218 & 6.9 & 335 \\
\hline AY-68-27-612 & 293404098382001 & 20060905 & 6.8 & 347 \\
\hline AY-68-27-612 & 293404098382001 & 20041203 & 7 & 351 \\
\hline AY-68-27-612 & 293404098382001 & 20021203 & 6.8 & 345 \\
\hline AY-68-27-612 & 293404098382001 & 20010604 & 6.7 & 327 \\
\hline AY-68-27-612 & 293404098382001 & 20000607 & 6.9 & 331 \\
\hline AY-68-27-612 & 293404098382001 & 19990525 & 6.8 & 229 \\
\hline AY-68-27-612 & 293404098382001 & 19981210 & 6.9 & 332 \\
\hline AY-68-27-609 & 293405098394201 & 20060905 & 6.9 & 328 \\
\hline AY-68-27-609 & 293405098394201 & 19981110 & 6.9 & 313 \\
\hline AY-68-28-519 & 293408098331301 & 20060829 & 6.8 & 363 \\
\hline AY-68-28-519 & 293408098331301 & 19981114 & 6.7 & 374 \\
\hline AY-68-28-407 & 293425098350801 & 20060911 & 7.1 & 284 \\
\hline AY-68-28-407 & 293425098350801 & 19981113 & 7.3 & 304 \\
\hline AY-68-27-611 & 293429098373801 & 20060906 & 6.9 & 323 \\
\hline AY-68-27-611 & 293429098373801 & 19981112 & 6.8 & 324 \\
\hline AY-68-28-517 & 293436098343001 & 20061219 & 6.8 & 300 \\
\hline AY-68-28-517 & 293436098343001 & 20060831 & 7.1 & 305 \\
\hline AY-68-28-517 & 293436098343001 & 20041209 & 7.1 & 318 \\
\hline AY-68-28-517 & 293436098343001 & 20021119 & 7 & 316 \\
\hline
\end{tabular}

B. 1 
Table B.1. (contd)

\begin{tabular}{|c|c|c|c|c|}
\hline $\begin{array}{l}\text { State Well } \\
\text { Number }\end{array}$ & $\begin{array}{c}\text { USGS } \\
\text { Identification } \\
\text { Number }\end{array}$ & $\begin{array}{l}\text { Sample Date } \\
\text { (yyyymmdd) }\end{array}$ & $\mathrm{pH}$ & TDS (mgL) \\
\hline AY-68-28-517 & 293436098343001 & 20010605 & 6.8 & 316 \\
\hline AY-68-28-517 & 293436098343001 & 20000628 & 6.9 & 298 \\
\hline AY-68-28-517 & 293436098343001 & 19990526 & 6.8 & 329 \\
\hline AY-68-28-517 & 293436098343001 & 19981208 & 6.8 & 335 \\
\hline AY-68-28-518 & 293439098324101 & 20060824 & 6.8 & 393 \\
\hline AY-68-28-518 & 293439098324101 & 19981211 & 7 & 342 \\
\hline AY-68-29-418 & 293456098280201 & 20060821 & 6.7 & 401 \\
\hline AY-68-29-418 & 293456098280201 & 19981209 & 6.7 & 407 \\
\hline AY-68-28-609 & 293459098321401 & 20060829 & 6.9 & 345 \\
\hline AY-68-28-609 & 293459098321401 & 19981111 & 6.9 & 306 \\
\hline AY-68-29-213 & 293504098270901 & 20060818 & 6.8 & 408 \\
\hline AY-68-29-213 & 293504098270901 & 19981105 & 6.7 & 391 \\
\hline AY-68-27-307 & 293508098375101 & 20060907 & 6.9 & 345 \\
\hline AY-68-27-307 & 293508098375101 & 19981023 & 6.9 & 311 \\
\hline AY-68-28-211 & 293516098325501 & 20061219 & 6.8 & 335 \\
\hline AY-68-28-211 & 293516098325501 & 20060824 & 6.9 & 340 \\
\hline AY-68-28-211 & 293516098325501 & 20041209 & 7.1 & 313 \\
\hline AY-68-28-211 & 293516098325501 & 20021120 & 7.1 & 319 \\
\hline AY-68-28-211 & 293516098325501 & 20010605 & 6.8 & 407 \\
\hline AY-68-28-211 & 293516098325501 & 20000629 & 6.9 & 320 \\
\hline AY-68-28-211 & 293516098325501 & 19990527 & 6.8 & 315 \\
\hline AY-68-28-211 & 293516098325501 & 19981114 & 6.9 & 301 \\
\hline AY-68-28-113 & 293516098362801 & 20060907 & 7 & 299 \\
\hline AY-68-28-113 & 293516098362801 & 19981112 & 6.9 & 280 \\
\hline AY-68-29-214 & 293520098254101 & 20060816 & 6.9 & 343 \\
\hline AY-68-29-214 & 293520098254101 & 19981108 & 6.8 & 355 \\
\hline AY-68-29-114 & 293528098274301 & 20060821 & 6.8 & 423 \\
\hline AY-68-29-114 & 293528098274301 & 19981103 & 6.7 & 378 \\
\hline AY-68-28-210 & 293530098343401 & 20060912 & 6.9 & 201 \\
\hline AY-68-28-210 & 293530098343401 & 19981026 & 6.9 & 323 \\
\hline AY-68-29-113 & 293534098282801 & 20060823 & 6.8 & 395 \\
\hline AY-68-29-113 & 293534098282801 & 19981107 & 6.8 & 364 \\
\hline AY-68-28-314 & 293535098304101 & 20061213 & 6.8 & 409 \\
\hline AY-68-28-314 & 293535098304101 & 20060831 & 6.7 & 420 \\
\hline AY-68-28-314 & 293535098304101 & 20041203 & 6.9 & 327 \\
\hline AY-68-28-314 & 293535098304101 & 20021205 & 6.7 & 375 \\
\hline AY-68-28-314 & 293535098304101 & 20010606 & 6.3 & 266 \\
\hline AY-68-28-314 & 293535098304101 & 20000608 & 6.8 & 401 \\
\hline AY-68-28-314 & 293535098304101 & 19990528 & 7 & 246 \\
\hline AY-68-28-314 & 293535098304101 & 19981207 & 6.7 & 366 \\
\hline
\end{tabular}


Table B.1. (contd)

\begin{tabular}{ccccc}
\hline $\begin{array}{c}\text { State Well } \\
\text { Number }\end{array}$ & $\begin{array}{c}\text { USGS } \\
\text { Identification } \\
\text { Number }\end{array}$ & $\begin{array}{c}\text { Sample Date } \\
\text { (yyyymmdd) }\end{array}$ & pH & TDS (mgL) \\
\hline AY-68-29-215 & 293537098262401 & 20060817 & 7.2 & 327 \\
\hline AY-68-29-215 & 293537098262401 & 19981105 & 6.9 & 315 \\
\hline AY-68-29-112 & 293559098284801 & 20060823 & 6.9 & 456 \\
\hline AY-68-29-112 & 293559098284801 & 19981209 & 6.8 & 373 \\
\hline AY-68-28-315 & 293611098311901 & 20060828 & 6.8 & 339 \\
\hline AY-68-28-315 & 293611098311901 & 19981111 & 6.8 & 354 \\
\hline AY-68-29-217 & 293615098262301 & 20060817 & 7.1 & 340 \\
\hline AY-68-29-217 & 293615098262301 & 19981109 & 7.1 & 236 \\
\hline AY-68-28-313 & 293635098302301 & 20060908 & 6.7 & 385 \\
\hline AY-68-28-313 & 293635098302301 & 19981104 & 6.9 & 288 \\
\hline AY-68-29-216 & 293643098264001 & 20061213 & 6.9 & 314 \\
\hline AY-68-29-216 & 293643098264001 & 20060822 & 6.9 & 295 \\
\hline AY-68-29-216 & 293643098264001 & 20041202 & 7 & 310 \\
\hline AY-68-29-216 & 293643098264001 & 20021204 & 6.9 & 328 \\
\hline AY-68-29-216 & 293643098264001 & 20010606 & 6.4 & 312 \\
\hline AY-68-29-216 & 293643098264001 & 20000629 & 6.9 & 313 \\
\hline AY-68-29-216 & 293643098264001 & 19990527 & 6.9 & 264 \\
\hline AY-68-29-216 & 293643098264001 & 19981109 & 6.9 & 300 \\
\hline AY-68-21-806 & 293746098265401 & 20060822 & 6.9 & 301 \\
\hline AY-68-21-806 & 293746098265401 & 19981207 & 6.8 & \\
\hline
\end{tabular}

B. 3 



\section{Appendix C}

\section{Select National Water Quality Assessment Central High}

Plains Aquifer Data 



\section{Appendix C}

\section{Select National Water Quality Assessment Central High Plains Aquifer Data}

The following tables were developed from a file provided by Richard Bell resulting from a query of the National Water Quality Assessment (NAWQA) database for all the inorganic, $\mathrm{pH}$, and total dissolved solids (TDS) data developed by NAWQA for the High Plains Aquifer.

The data was queried for all the data that might regard the Ogallala hydrogeologic unit in the Central High Plains area defined by NAWQA, and then further subset by the site lists for each of the nested studies available from http://co.water.usgs.gov/nawqa/hpgw/datarep/TOC.html. This left aside the Central High Plains Quaternary unit major aquifer study data as well as the urban land use study data around Wichita, Kansas, for instance, are in the Quaternary unit of the Central High Plains.

The following tables contain only records with data on arsenic, cadmium, lead, $\mathrm{pH}$, or TDS.

Some sites are utilized in more than one of the studies, and so these sites, and even data from them, may appear in two of the tables. 
Table C.1. Central High Plains irrigated agriculture land use study.

\begin{tabular}{|c|c|c|c|c|c|c|c|c|c|c|c|c|c|}
\hline staid & Latitude1983 & Longitude1983 & Datetime & $\begin{array}{c}\text { As } \\
\text { rem }\end{array}$ & $\begin{array}{c}\text { As } \\
(\mu \mathrm{gl})\end{array}$ & $\begin{array}{c}\mathrm{Cd} \\
\mathrm{rem}\end{array}$ & $\begin{array}{c}\mathrm{Cd} \\
(\mu \mathrm{gl})\end{array}$ & $\begin{array}{c}\mathrm{Cr} \\
\mathrm{rem}\end{array}$ & $\begin{array}{c}\mathrm{Cr} \\
(\mu \mathrm{gl})\end{array}$ & $\begin{array}{c}\mathrm{Pb} \\
\mathrm{rem}\end{array}$ & $\begin{array}{c}\mathrm{Pb} \\
(\mu \mathrm{gl})\end{array}$ & $\mathrm{pH}$ & $\begin{array}{c}\text { TDS } \\
(\mathrm{mg} / \mathrm{l})\end{array}$ \\
\hline 360159103044401 & 36.0330666667 & -103.0789833333 & 9/11/2000 3:00:00 PM & & & & & & & & & 7.26 & 366 \\
\hline 364846102161201 & 36.8129916667 & -102.2700000000 & 9/17/2000 10:00:00 AM & & & & & & & & & 7.69 & 542 \\
\hline 370033100534204 & 37.0091861111 & -100.8952583333 & 8/27/1999 2:00:00 PM & & & & & & & & & 7.65 & 331 \\
\hline 370033100534204 & 37.0091861111 & -100.8952583333 & 8/27/1999 2:09:00 PM & & 4.55 & $<$ & 1 & & 2.6 & $<$ & 1 & & \\
\hline 370033100534204 & 37.0091861111 & -100.8952583333 & 9/13/2000 9:00:00 AM & & & & & & & & & 7.39 & 328 \\
\hline 370941101540001 & 37.1615305556 & -101.9002388889 & 9/16/2000 1:00:00 PM & & & & & & & & & 7.79 & 964 \\
\hline 371303102003001 & 37.2177027778 & -102.0086083333 & 9/14/2000 5:00:00 PM & & & & & & & & & 7.54 & 624 \\
\hline 371728101311401 & 37.2912166667 & -101.5207888889 & 9/15/2000 11:00:00 AM & & & & & & & & & 7.38 & 782 \\
\hline 371909101413101 & 37.3193805556 & -101.6921333333 & 9/16/2000 10:00:00 AM & & & & & & & & & 7.66 & 720 \\
\hline 372511100155601 & 37.4199638889 & -100.2658138889 & 9/27/2000 9:00:00 AM & & & & & & & & & 7.26 & 1090 \\
\hline 373234099430201 & 37.5429194444 & -99.7173055556 & 9/25/2000 1:00:00 PM & & & & & & & & & 7.73 & 287 \\
\hline 373346100005701 & 37.5630277778 & -100.0158333333 & 9/27/2000 2:00:00 PM & & & & & & & & & 7.61 & 300 \\
\hline 373904099545701 & 37.6512222222 & -99.9158916667 & 9/28/2000 1:00:00 PM & & & & & & & & & 7.36 & 380 \\
\hline 374005101433501 & 37.6681833333 & -101.7265277778 & 8/8/2000 8:00:00 AM & & & & & & & & & 7.6 & 400 \\
\hline 374220100422501 & 37.7055833333 & -100.7069722222 & 2/4/1999 11:00:00 AM & & & & & & & & & 7.19 & 642 \\
\hline 374220100422501 & 37.7055833333 & -100.7069722222 & 6/28/2000 11:00:00 AM & & & & & & & & & 6.93 & 554 \\
\hline 374412100453201 & 37.7367777778 & -100.7588333333 & 7/10/2000 11:00:00 AM & & & & & & & & & 7.43 & 675 \\
\hline 374412100453201 & 37.7367777778 & -100.7588333333 & 11/27/2000 6:00:00 PM & & & & & & & & & & \\
\hline 374412100453201 & 37.7367777778 & -100.7588333333 & 8/15/2001 11:00:00 AM & & & & & & & & & 7.68 & \\
\hline 374430100093801 & 37.7417833333 & -100.1606722222 & 9/28/2000 9:00:00 AM & & & & & & & & & 7.41 & 489 \\
\hline 374625100490701 & 37.7735555556 & -100.8186944444 & 6/29/2000 11:00:00 AM & & & & & & & & & 6.91 & 680 \\
\hline 374625100490701 & 37.7735555556 & -100.8186944444 & 8/14/2001 10:00:00 AM & & & & & & & & & 7.31 & \\
\hline 374642100291701 & 37.7783972222 & -100.4883277778 & 6/30/2000 12:00:00 PM & & & & & & & & & 7.21 & 396 \\
\hline 374750101553501 & 37.7973166667 & -101.9266305556 & 8/9/2000 9:00:00 AM & & & & & & & & & 7.7 & 493 \\
\hline 375106100544301 & 37.8516750000 & -100.9120027778 & 9/26/2000 2:00:00 PM & & & & & & & & & 7.62 & 300 \\
\hline 375251101135301 & 37.8808472222 & -101.2314055556 & 8/11/2000 10:00:00 AM & & & & & & & & & 7.34 & 1306 \\
\hline 375502100363601 & 37.9173972222 & -100.6102500000 & 9/26/2000 10:00:00 AM & & & & & & & & & 7.9 & 485 \\
\hline
\end{tabular}


Table C.1. (contd)

\begin{tabular}{|c|c|c|c|c|c|c|c|c|c|c|c|c|c|}
\hline staid & Latitude 1983 & Longitude1983 & Datetime & $\begin{array}{c}\text { As } \\
\text { rem }\end{array}$ & $\begin{array}{c}\text { As } \\
(\mu \mathrm{gl})\end{array}$ & $\begin{array}{c}\mathrm{Cd} \\
\mathrm{rem}\end{array}$ & $\begin{array}{c}\mathrm{Cd} \\
(\mu \mathrm{gl})\end{array}$ & $\begin{array}{c}\mathrm{Cr} \\
\text { rem }\end{array}$ & $\begin{array}{c}\mathrm{Cr} \\
(\mu \mathrm{gl})\end{array}$ & $\begin{array}{c}\mathrm{Pb} \\
\text { rem }\end{array}$ & $\begin{array}{c}\mathrm{Pb} \\
(\mu \mathrm{gl})\end{array}$ & $\mathrm{pH}$ & $\begin{array}{c}\mathrm{TDS} \\
(\mathrm{mg} / \mathrm{l})\end{array}$ \\
\hline 375734100452301 & 37.9595833333 & -100.7564166667 & 2/2/1999 11:30:00 AM & & & & & & & & & 7 & 1058 \\
\hline 375855100484001 & 37.9820833333 & -100.8110000000 & 2/3/1999 11:00:00 AM & & & & & & & & & 6.96 & 4916 \\
\hline 375855100484001 & 37.9820833333 & -100.8110000000 & 6/27/2000 12:00:00 PM & & & & & & & & & 6.81 & 4512 \\
\hline 380256101035901 & 38.0489111111 & -101.0664027778 & 8/10/2000 8:00:00 AM & & & & & & & & & 7.2 & 782 \\
\hline 381201100495101 & 38.2004388889 & -100.8309555556 & 7/11/2000 12:00:00 PM & & & & & & & & & 6.99 & 1036 \\
\hline 383334101131301 & 38.5595277778 & -101.2205444444 & 8/8/2000 3:00:00 PM & & & & & & & & & 7.7 & 374 \\
\hline 383803101084701 & 38.6343277778 & -101.1466166667 & 7/13/2000 11:00:00 AM & & & & & & & & & 7.37 & 382 \\
\hline 383936101120801 & 38.6602222222 & -101.2023750000 & 7/12/2000 3:00:00 PM & & & & & & & & & 7.44 & 407 \\
\hline 384422101434201 & 38.7395055556 & -101.7285472222 & 7/14/2000 12:00:00 PM & & & & & & & & & 7.76 & 277 \\
\hline
\end{tabular}


Table C.2. Central High Plains Ogallala Unit major aquifer study.

\begin{tabular}{|c|c|c|c|c|c|c|c|c|c|c|c|c|c|}
\hline staid & Latitude1983 & Longitude 1983 & Datetime & $\begin{array}{c}\mathrm{As} \\
\mathrm{rem}\end{array}$ & $\begin{array}{c}\text { As } \\
(\mu \mathrm{gl})\end{array}$ & $\begin{array}{c}\mathrm{Cd} \\
\text { rem }\end{array}$ & $\begin{array}{c}\mathrm{Cd} \\
(\mu \mathrm{gl})\end{array}$ & $\begin{array}{c}\mathrm{Cr} \\
\text { rem }\end{array}$ & $\begin{array}{c}\mathrm{Cr} \\
(\mu \mathrm{gl})\end{array}$ & $\begin{array}{c}\mathrm{Pb} \\
\text { rem }\end{array}$ & $\begin{array}{c}\mathrm{Pb} \\
(\mu \mathrm{gl})\end{array}$ & $\mathrm{pH}$ & $\begin{array}{c}\text { TDS } \\
(\mathrm{mg} / \mathrm{l})\end{array}$ \\
\hline 344800101324901 & 34.8002305556 & -101.5469888889 & 7/14/1999 10:00:00 AM & & & & & & & & & 7.5 & 325 \\
\hline 344800101324901 & 34.8002305556 & -101.5469888889 & 7/14/1999 10:09:00 AM & & 5.57 & $<$ & 1 & & 1.1 & $<$ & 1 & & \\
\hline 345826100580501 & 34.9740000000 & -100.9680611111 & 6/28/1999 11:00:00 AM & & & & & & & & & 7.3 & 359 \\
\hline 345826100580501 & 34.9740000000 & -100.9680611111 & 6/28/1999 11:09:00 AM & & 3 & $<$ & 1 & $<$ & 1 & $<$ & 1 & & \\
\hline 351656101161101 & 35.2822222222 & -101.2699861111 & 5/19/1999 9:00:00 AM & & 1.63 & $<$ & 1 & & 2.7 & $<$ & 1 & 7.5 & 291 \\
\hline 351656101161101 & 35.2822222222 & -101.2699861111 & 4/28/2010 2:30:00 PM & & 1.894 & $\mathrm{E}$ & 0.0114 & & 2.288 & $<$ & 0.03 & 7.52 & 290.76 \\
\hline 351914101204401 & 35.3207361111 & -101.3457333333 & 7/1/1999 8:00:00 AM & & & & & & & & & 7.5 & 330 \\
\hline 351914101204401 & 35.3207361111 & -101.3457333333 & 7/1/1999 8:09:00 AM & & 1.35 & $<$ & 1 & & 5.2 & & 1.889 & & \\
\hline 352035100293301 & 35.3432333333 & -100.4926000000 & 7/13/1999 9:00:00 AM & & & & & & & & & 7.3 & 299 \\
\hline 352035100293301 & 35.3432333333 & -100.4926000000 & 7/13/1999 9:09:00 AM & & 2.11 & $<$ & 1 & $<$ & 1 & $<$ & 1 & & \\
\hline 352249100425401 & 35.3804833333 & -100.7152222222 & 6/30/1999 9:00:00 AM & & & & & & & & & 7.5 & 213 \\
\hline 352249100425401 & 35.3804833333 & -100.7152222222 & 6/30/1999 9:09:00 AM & & 2.04 & $<$ & 1 & $<$ & 1 & $<$ & 1 & & \\
\hline 352249100425401 & 35.3804833333 & -100.7152222222 & 4/29/2010 10:40:00 AM & & 2.124 & $<$ & 0.02 & & 0.1261 & & 0.0445 & 7.59 & 193.11 \\
\hline 352513101372101 & 35.4202777778 & -101.6225000000 & 5/20/1999 8:00:00 AM & $<$ & 1 & $<$ & 1 & $<$ & 1 & $<$ & 1 & 7.7 & 250 \\
\hline 352513101372101 & 35.4202777778 & -101.6225000000 & 4/28/2010 10:30:00 AM & & 1.292 & $\mathrm{E}$ & 0.0192 & & 0.332 & & 0.0798 & 7.7 & 273.32 \\
\hline 352909101084001 & 35.4860305556 & -101.1446416667 & 7/1/1999 2:00:00 PM & & & & & & & & & 7.7 & 1028 \\
\hline 352909101084001 & 35.4860305556 & -101.1446416667 & 7/1/1999 2:09:00 PM & & 3.39 & $<$ & 1 & & 3.5 & $<$ & 1 & & \\
\hline 353110100550401 & 35.5195138889 & -100.9178944444 & 6/29/1999 10:00:00 AM & & & & & & & & & 7.6 & 416 \\
\hline 353110100550401 & 35.5195138889 & -100.9178944444 & 6/29/1999 10:09:00 AM & & 3.2 & $<$ & 1 & & 3.5 & $<$ & 1 & & \\
\hline 353110100550401 & 35.5195138889 & -100.9178944444 & 4/29/2010 2:40:00 PM & & 1.703 & & 0.0372 & & 3.18 & & 0.1038 & 7.34 & 474.8 \\
\hline 353110100550401 & 35.5195138889 & -100.9178944444 & 4/11/2012 11:00:00 AM & & 1.66 & & 0.0374 & & 3.366 & & 0.1823 & 7.46 & 482.11 \\
\hline 353941102350201 & 35.6614416667 & -102.5841638889 & 7/15/1999 11:00:00 AM & & & & & & & & & 7.7 & 285 \\
\hline 353941102350201 & 35.6614416667 & -102.5841638889 & 7/15/1999 11:09:00 AM & & 2.83 & $<$ & 1 & $<$ & 1 & $<$ & 1 & & \\
\hline 354248100501501 & 35.7133833333 & -100.8375138889 & 7/19/1999 8:00:00 AM & & & & & & & & & 7.6 & 322 \\
\hline 354248100501501 & 35.7133833333 & -100.8375138889 & 7/19/1999 8:09:00 AM & & 1.56 & $<$ & 1 & & 1.2 & $<$ & 1 & & \\
\hline 354331102183601 & 35.7252833333 & -102.3100888889 & 6/23/1999 9:00:00 AM & & & & & & & & & 7.7 & 274 \\
\hline 354331102183601 & 35.7252833333 & -102.3100888889 & 6/23/1999 9:09:00 AM & & 3.29 & $<$ & 1 & $<$ & 1 & $<$ & 1 & & \\
\hline 354331102183601 & 35.7252833333 & -102.3100888889 & 4/30/2010 3:00:00 PM & & 3.384 & & 0.0402 & & 0.9077 & & 0.0659 & 7.7 & 252.82 \\
\hline
\end{tabular}


Table C.2. (contd)

\begin{tabular}{|c|c|c|c|c|c|c|c|c|c|c|c|c|c|}
\hline staid & Latitude 1983 & Longitude 1983 & Datetime & $\begin{array}{c}\text { As } \\
\text { rem }\end{array}$ & $\begin{array}{c}\text { As } \\
(\mu \mathrm{gl})\end{array}$ & $\begin{array}{c}\mathrm{Cd} \\
\mathrm{rem}\end{array}$ & $\begin{array}{c}\mathrm{Cd} \\
(\mu \mathrm{gl})\end{array}$ & $\begin{array}{c}\mathrm{Cr} \\
\text { rem }\end{array}$ & $\begin{array}{c}\mathrm{Cr} \\
(\mu \mathrm{gl})\end{array}$ & $\begin{array}{c}\mathrm{Pb} \\
\text { rem }\end{array}$ & $\begin{array}{c}\mathrm{Pb} \\
(\mu \mathrm{gl})\end{array}$ & $\mathrm{pH}$ & $\begin{array}{c}\text { TDS } \\
(\mathrm{mg} / \mathrm{l})\end{array}$ \\
\hline 354348102543601 & 35.7300000000 & -102.9100000000 & 7/21/1999 11:00:00 AM & & & & & & & & & 7.7 & 243 \\
\hline 354348102543601 & 35.7300000000 & -102.9100000000 & 7/21/1999 11:09:00 AM & & 2.31 & $<$ & 1 & $<$ & 1 & $<$ & 1 & & \\
\hline 354656099480301 & 35.7822361111 & -99.8010888889 & 5/17/1999 11:00:00 AM & & 3.52 & $<$ & 1 & $<$ & 1 & $<$ & 1 & 7.32 & 279 \\
\hline 354728102295901 & 35.7913333333 & -102.4999944444 & 7/16/1999 12:00:00 PM & & & & & & & & & 7.6 & 297 \\
\hline 354728102295901 & 35.7913333333 & -102.4999944444 & 7/16/1999 12:09:00 PM & & 1.95 & $<$ & 1 & & 2.2 & $<$ & 1 & & \\
\hline 354918102020901 & 35.8218444444 & -102.0360611111 & 6/23/1999 2:00:00 PM & & & & & & & & & 8 & 324 \\
\hline 354918102020901 & 35.8218444444 & -102.0360611111 & 6/23/1999 2:09:00 PM & $<$ & 1 & $<$ & 1 & & 2.2 & $<$ & 1 & & \\
\hline 355701100313001 & 35.9504500000 & -100.5252333333 & 5/18/1999 10:00:00 AM & & & & & & & & & 7.4 & 328 \\
\hline 355701100313001 & 35.9504500000 & -100.5252333333 & 5/18/1999 10:09:00 AM & & 1.23 & $<$ & 1 & & 1 & $<$ & 1 & & \\
\hline 355701100313001 & 35.9504500000 & -100.5252333333 & 4/15/2010 4:00:00 PM & & 1.175 & $<$ & 0.02 & & 0.8586 & & 0.2566 & 7.5 & 328.53 \\
\hline 355852101274101 & 35.9812666667 & -101.4616500000 & 7/2/1999 12:00:00 PM & & & & & & & & & 7.6 & 294 \\
\hline 355852101274101 & 35.9812666667 & -101.4616500000 & 7/2/1999 12:09:00 PM & & 1.6 & $<$ & 1 & & 2 & $<$ & 1 & & \\
\hline 355852101274101 & 35.9812666667 & -101.4616500000 & 4/30/2010 11:00:00 AM & & 2.398 & & 0.0701 & & 1.796 & & 0.0354 & 7.62 & 284.66 \\
\hline 355916103215201 & 35.9878666667 & -103.3644888889 & 6/25/1999 12:00:00 PM & & & & & & & & & 7.7 & 864 \\
\hline 355916103215201 & 35.9878666667 & -103.3644888889 & 6/25/1999 12:09:00 PM & & 3.65 & $<$ & 1 & $<$ & 1 & $<$ & 1 & & \\
\hline 360703102361901 & 36.1177555556 & -102.6055055556 & 6/22/1999 10:00:00 AM & & & & & & & & & 7.7 & 302 \\
\hline 360703102361901 & 36.1177555556 & -102.6055055556 & 6/22/1999 10:09:00 AM & & 2.42 & $<$ & 1 & $<$ & 1 & $<$ & 1 & & \\
\hline 360838102560301 & 36.1439888889 & -102.9342472222 & 6/24/1999 8:00:00 AM & & & & & & & & & 7.6 & 267 \\
\hline 360838102560301 & 36.1439888889 & -102.9342472222 & 6/24/1999 8:09:00 AM & & 1.91 & $<$ & 1 & $<$ & 1 & $<$ & 1 & & \\
\hline 360944100162101 & 36.1622222222 & -100.2725000000 & 4/12/1999 9:00:00 AM & & 2.83 & $<$ & 1 & & 3.5 & $<$ & 1 & 7.77 & 314 \\
\hline 361014100221001 & 36.1706500000 & -100.3695611111 & 4/8/1999 11:00:00 AM & & 2.95 & $<$ & 1 & & 1.1 & $<$ & 1 & 7.53 & 397 \\
\hline 361049100564901 & 36.1802777778 & -100.9469444444 & 5/21/1999 12:00:00 PM & & 1.55 & $<$ & 1 & & 3.2 & $<$ & 1 & 7.66 & 420 \\
\hline 361049100564901 & 36.1802777778 & -100.9469444444 & 4/15/2010 11:00:00 AM & & 3.475 & & 0.0484 & & 0.3805 & & 0.5952 & 7.44 & 355.1 \\
\hline 361054101393601 & 36.1817972222 & -101.6600444444 & 6/21/1999 11:00:00 AM & & & & & & & & & 7.6 & 367 \\
\hline 361054101393601 & 36.1817972222 & -101.6600444444 & 6/21/1999 11:09:00 AM & & 2.07 & $<$ & 1 & & 1.3 & $<$ & 1 & & \\
\hline 361114099420501 & 36.1873944444 & -99.7016138889 & 7/22/1999 11:00:00 AM & & & & & & & & & 7.3 & 413 \\
\hline 361114099420501 & 36.1873944444 & -99.7016138889 & 7/22/1999 11:09:00 AM & & 1.75 & $<$ & 1 & $<$ & 1 & $<$ & 1 & & \\
\hline 361517102065301 & 36.2547222222 & -102.1147222222 & 5/26/1999 9:00:00 AM & $<$ & 1 & $<$ & 1 & & 3.3 & $<$ & 1 & 7.8 & 329 \\
\hline 361517102065301 & 36.2547222222 & -102.1147222222 & 4/27/2010 2:00:00 PM & & 0.8856 & & 0.0511 & & 2.921 & & 0.1844 & 7.73 & 319.78 \\
\hline 362115101173901 & 36.3543138889 & -101.2943222222 & 5/25/1999 10:00:00 AM & & 2.37 & $<$ & 1 & & 1.8 & $<$ & 1 & 7.6 & 416 \\
\hline
\end{tabular}


Table C.2. (contd)

\begin{tabular}{|c|c|c|c|c|c|c|c|c|c|c|c|c|c|}
\hline staid & Latitude1983 & Longitude1983 & Datetime & $\begin{array}{c}\mathrm{As} \\
\mathrm{rem}\end{array}$ & $\begin{array}{c}\text { As } \\
(\mu \mathrm{gl})\end{array}$ & $\begin{array}{c}\mathrm{Cd} \\
\mathrm{rem}\end{array}$ & $\begin{array}{c}\mathrm{Cd} \\
(\mu \mathrm{gl})\end{array}$ & $\begin{array}{c}\mathrm{Cr} \\
\text { rem }\end{array}$ & $\begin{array}{c}\mathrm{Cr} \\
(\mu \mathrm{gl})\end{array}$ & $\begin{array}{c}\mathrm{Pb} \\
\text { rem }\end{array}$ & $\begin{array}{c}\mathrm{Pb} \\
(\mu \mathrm{gl})\end{array}$ & $\mathrm{pH}$ & $\begin{array}{c}\text { TDS } \\
(\mathrm{mg} / \mathrm{l})\end{array}$ \\
\hline 362134102035101 & 36.3594722222 & -102.0642722222 & 5/25/1999 2:00:00 PM & & 1.39 & $<$ & 1 & & 1.8 & $<$ & 1 & 7.9 & 283 \\
\hline 362134102035101 & 36.3594722222 & -102.0642722222 & 5/1/2010 10:00:00 AM & & 1.119 & & 0.0799 & & 1.673 & & 0.135 & 7.76 & 280.71 \\
\hline 362615100435801 & 36.4376194444 & -100.7329805556 & 5/24/1999 11:00:00 AM & & 5.48 & $<$ & 1 & & 3.9 & $<$ & 1 & 7.6 & 382 \\
\hline 362744102334901 & 36.3963833333 & -102.5627305556 & 7/20/1999 9:00:00 AM & & & & & & & & & 8.3 & 468 \\
\hline 362744102334901 & 36.3963833333 & -102.5627305556 & 7/20/1999 9:09:00 AM & & 7.61 & $<$ & 1 & & & $<$ & 1 & & \\
\hline 363057101384701 & 36.5160638889 & -101.6466611111 & 5/27/1999 8:00:00 AM & & 5.25 & $<$ & 1 & & 1.2 & $<$ & 1 & 7.7 & 268 \\
\hline 363104100035501 & 36.5178333333 & -100.0652805556 & 4/9/1999 9:30:00 AM & & 4.51 & $<$ & 1 & $<$ & 1 & $<$ & 1 & 7.6 & 308 \\
\hline 363104100035501 & 36.5178333333 & -100.0652805556 & 4/14/2010 3:30:00 PM & & 5.124 & $\mathrm{E}$ & 0.0128 & & 0.7447 & & 0.0453 & 7.55 & 302.64 \\
\hline 363154099310401 & 36.5316666667 & -99.5180305556 & 7/22/1999 2:00:00 PM & & & & & & & & & 7.4 & 288 \\
\hline 363154099310401 & 36.5316666667 & -99.5180305556 & 7/22/1999 2:09:00 PM & & 2.9 & $<$ & 1 & $<$ & 1 & $<$ & 1 & & \\
\hline 363154099310401 & 36.5316666667 & -99.5180305556 & 4/13/2010 11:00:00 AM & & 1.402 & $<$ & 0.02 & & 0.758 & & 0.2055 & 7.03 & 261.8 \\
\hline 363157102565601 & 36.5326055556 & -102.9491083333 & 4/16/1999 10:00:00 AM & & 2.02 & $<$ & 1 & & 1.1 & & 2.289 & 8.08 & 276 \\
\hline 363239100301801 & 36.5443222222 & -100.5051916667 & 4/6/1999 10:00:00 AM & & 9.73 & $<$ & 1 & & 1.8 & $<$ & 1 & 7.76 & 381 \\
\hline 363239100301801 & 36.5443222222 & -100.5051916667 & 4/13/2010 3:00:00 PM & & 9.111 & $\mathrm{E}$ & 0.0486 & & 1.515 & $\mathrm{E}$ & 0.0714 & 7.56 & 376.87 \\
\hline 363427102440401 & 36.5743916667 & -102.7346000000 & 4/15/1999 9:00:00 AM & & 2.65 & $<$ & 1 & & 1.5 & $<$ & 1 & 8.06 & 346 \\
\hline 363427102440401 & 36.5743916667 & -102.7346000000 & 5/1/2010 1:00:00 PM & & 2.743 & & 0.0227 & & 1.307 & & 0.0352 & 7.59 & 323.36 \\
\hline 363427102440401 & 36.5743916667 & -102.7346000000 & 4/10/2012 2:00:00 PM & & 2.655 & & 0.0171 & & 1.594 & & 0.312 & 7.48 & 334.16 \\
\hline 364219101394101 & 36.7054750000 & -101.6616055556 & 6/11/1999 12:00:00 PM & & & & & & & & & 7.8 & 312 \\
\hline 364219101394101 & 36.7054750000 & -101.6616055556 & 6/11/1999 12:09:00 PM & & 6.04 & $<$ & 1 & & 1.2 & $<$ & 1 & & \\
\hline 364411102321201 & 36.7365861111 & -102.5368444444 & 6/10/1999 8:00:00 AM & & & & & & & & & 7.7 & 466 \\
\hline 364411102321201 & 36.7365861111 & -102.5368444444 & 6/10/1999 8:09:00 AM & & 2.84 & $<$ & 1 & $<$ & 1 & $<$ & 1 & & \\
\hline 365223102113001 & 36.8731083333 & -102.1917055556 & 4/14/1999 11:00:00 AM & & 1.37 & $<$ & 1 & & 1.1 & $<$ & 1 & 7.94 & 303 \\
\hline 365223102113001 & 36.8731083333 & -102.1917055556 & 4/26/2010 11:00:00 AM & & 2.077 & & 0.0595 & & 1.032 & & 0.1144 & 7.73 & 285.71 \\
\hline 365422101083701 & 36.9062000000 & -101.1436916667 & 6/11/1999 2:00:00 PM & & & & & & & & & 7.6 & 328 \\
\hline 365422101083701 & 36.9062000000 & -101.1436916667 & 6/11/1999 2:09:00 PM & & 3.51 & $<$ & 1 & & 3.7 & $<$ & 1 & & \\
\hline 365445100381901 & 36.9126527778 & -100.6387472222 & 4/7/1999 11:00:00 AM & & 4.24 & $<$ & 1 & & 2.4 & $<$ & 1 & 7.6 & 363 \\
\hline 365445100381901 & 36.9126527778 & -100.6387472222 & 4/14/2010 10:00:00 AM & & 3.767 & & 0.0689 & & 1.409 & & 0.101 & 7.58 & 408.83 \\
\hline 365821101375301 & 36.9727250000 & -101.6313944444 & 5/28/1999 12:00:00 PM & & 1.54 & $<$ & 1 & & 1.4 & $<$ & 1 & 7.4 & 545 \\
\hline 365934101573001 & 36.9929388889 & -101.9584083333 & 4/13/1999 10:00:00 AM & $<$ & 1 & $<$ & 1 & $<$ & 1 & $<$ & 1 & 7.49 & \\
\hline 365934101573001 & 36.9929388889 & -101.9584083333 & 4/27/2010 10:00:00 AM & & 0.9352 & & 0.0238 & & 0.3169 & & 0.3088 & 7.45 & 601.18 \\
\hline
\end{tabular}


Table C.2. (contd)

\begin{tabular}{|c|c|c|c|c|c|c|c|c|c|c|c|c|c|}
\hline staid & Latitude1983 & Longitude1983 & Datetime & $\begin{array}{c}\text { As } \\
\text { rem }\end{array}$ & $\begin{array}{c}\text { As } \\
(\mu \mathrm{gl})\end{array}$ & $\begin{array}{c}\mathrm{Cd} \\
\mathrm{rem}\end{array}$ & $\begin{array}{c}\mathrm{Cd} \\
(\mu \mathrm{gl})\end{array}$ & $\begin{array}{l}\mathrm{Cr} \\
\mathrm{rem}\end{array}$ & $\begin{array}{c}\mathrm{Cr} \\
(\mu \mathrm{gl})\end{array}$ & $\begin{array}{c}\mathrm{Pb} \\
\mathrm{rem}\end{array}$ & $\begin{array}{c}\mathrm{Pb} \\
(\mu \mathrm{gl})\end{array}$ & $\mathrm{pH}$ & $\begin{array}{c}\text { TDS } \\
(\mathrm{mg} / \mathrm{l})\end{array}$ \\
\hline 370358100510301 & 37.0662222222 & -100.8507500000 & 4/15/1999 10:00:00 AM & & 1.51 & $<$ & 1 & & 2.2 & $<$ & 1 & 7.56 & 323 \\
\hline 370458101514401 & 37.0827500000 & -101.8621111111 & 4/22/1999 10:00:00 AM & & 2.12 & $<$ & 1 & & 1.8 & $<$ & 1 & 7.52 & 351 \\
\hline 370458101514401 & 37.0827500000 & -101.8621111111 & 4/25/2010 5:00:00 PM & & 1.958 & $<$ & 0.02 & & 1.107 & & 0.1159 & 7.46 & 329.45 \\
\hline 370458101514401 & 37.0827500000 & -101.8621111111 & 4/10/2012 10:00:00 AM & & 2.674 & $<$ & 0.016 & & 1.589 & & 0.3097 & 7.29 & 335.24 \\
\hline 370724100281601 & 37.1234166667 & -100.4709722222 & 4/23/1999 11:00:00 AM & & 2.9 & $<$ & 1 & & 1.9 & $<$ & 1 & 7.48 & 517 \\
\hline 371738101220301 & 37.2940000000 & -101.3674444444 & 4/20/1999 10:00:00 AM & & 1.81 & $<$ & 1 & & 1.9 & $<$ & 1 & 7.54 & 347 \\
\hline 371738101220301 & 37.2940000000 & -101.3674444444 & 3/17/2010 2:00:00 PM & & 2.022 & & 0.0688 & & 1.74 & & 0.115 & 7.51 & 372.99 \\
\hline 372534100443501 & 37.4261944444 & -100.7429722222 & 4/16/1999 10:00:00 AM & & 1.43 & $<$ & 1 & $<$ & 1 & $<$ & 1 & 7.58 & 360 \\
\hline 372534100443501 & 37.4261944444 & -100.7429722222 & 3/18/2010 10:30:00 AM & $\mathrm{E}$ & 0.434 & & 0.224 & $<$ & 1.2 & $\mathrm{E}$ & 0.167 & 7 & 633.49 \\
\hline 372649101344701 & 37.4468611111 & -101.5799444444 & 4/19/1999 11:00:00 AM & $<$ & 1 & $<$ & 1 & $<$ & 1 & $<$ & 1 & 7.64 & 296 \\
\hline 372956099512201 & 37.4987777778 & -99.8561388889 & 5/26/1999 3:00:00 PM & & 2.51 & $<$ & 1 & $<$ & 1 & $<$ & 1 & 7.55 & 297 \\
\hline 373229101193201 & 37.5415000000 & -101.3254166667 & 4/21/1999 11:00:00 AM & $<$ & 1 & $<$ & 1 & & 2.8 & $<$ & 1 & 7.46 & 529 \\
\hline 373229101193201 & 37.5415000000 & -101.3254166667 & 3/17/2010 10:00:00 AM & & 1.341 & & 0.0741 & & 2.636 & & 0.1337 & 7.35 & 519.8 \\
\hline 373345101070801 & 37.5625555556 & -101.1188611111 & 4/6/1999 11:00:00 AM & $<$ & 1 & $<$ & 1 & & 1.3 & $<$ & 1 & 7.58 & 345 \\
\hline 373507102162001 & 37.5855500000 & -102.2724555556 & 6/9/1999 9:00:00 AM & & & & & & & & & 7.6 & 380 \\
\hline 373507102162001 & 37.5855500000 & -102.2724555556 & 6/9/1999 9:09:00 AM & $<$ & 1 & $<$ & 1 & & & $<$ & 1 & & \\
\hline 373527100312701 & 37.5908055556 & -100.5240833333 & 4/9/1999 10:00:00 AM & & 3.43 & $<$ & 1 & & 1.2 & $<$ & 1 & 7.7 & 283 \\
\hline 373527100312701 & 37.5908055556 & -100.5240833333 & 3/18/2010 1:00:00 PM & & 2.81 & & 0.0291 & & 2.019 & $<$ & 0.03 & 7.4 & 264.87 \\
\hline 373559102314901 & 37.5997444444 & -102.5290666667 & 6/9/1999 2:00:00 PM & & & & & & & & & 7.8 & 312 \\
\hline 373559102314901 & 37.5997444444 & -102.5290666667 & 6/9/1999 2:09:00 PM & $<$ & 1 & $<$ & 1 & $<$ & 1 & $<$ & 1 & & \\
\hline 373732099291201 & 37.6255277778 & -99.4865555556 & 5/19/1999 4:00:00 PM & & 1.43 & $<$ & 1 & & 1.4 & $<$ & 1 & 7.47 & 288 \\
\hline 373732099291201 & 37.6255277778 & -99.4865555556 & 3/16/2010 11:00:00 AM & & 1.424 & & 0.0339 & & 1.534 & & 0.2582 & 7.24 & 362.08 \\
\hline 373732099291201 & 37.6255277778 & -99.4865555556 & 4/12/2012 10:00:00 AM & & 1.397 & $<$ & 0.016 & & 1.511 & & 0.2459 & 7.22 & 320.99 \\
\hline 374535102110301 & 37.7597222222 & -102.1841666667 & 6/8/1999 10:00:00 AM & & & & & & & & & 7.7 & 381 \\
\hline 374535102110301 & 37.7597222222 & -102.1841666667 & 6/8/1999 10:09:00 AM & $<$ & 1 & $<$ & 1 & $<$ & 1 & $<$ & 1 & & \\
\hline 374535102110301 & 37.7597222222 & -102.1841666667 & 3/15/2010 2:00:00 PM & & 0.3261 & & 0.1319 & $<$ & 0.12 & $<$ & 0.03 & 7.97 & 398.34 \\
\hline 374650100181901 & 37.7805000000 & -100.3053888889 & 4/14/1999 9:00:00 AM & & 1.46 & $<$ & 1 & & 1.1 & $<$ & 1 & 7.49 & 370 \\
\hline 374650100181901 & 37.7805000000 & -100.3053888889 & 3/18/2010 5:00:00 PM & & 1.082 & & 0.063 & & 0.538 & & 0.0859 & 7.2 & 955.66 \\
\hline 375129100532301 & 37.8580555556 & -100.8898055556 & 4/18/1999 3:00:00 PM & $<$ & 1 & $<$ & 1 & & 1.5 & $<$ & 1 & 7.6 & 243 \\
\hline 375447099245001 & 37.9130555556 & -99.4137777778 & 5/19/1999 10:00:00 AM & & 2.47 & $<$ & 1 & $<$ & 1 & $<$ & 1 & 7.32 & 1064 \\
\hline
\end{tabular}


Table C.2. (contd)

\begin{tabular}{|c|c|c|c|c|c|c|c|c|c|c|c|c|c|}
\hline staid & Latitude1983 & Longitude1983 & Datetime & $\begin{array}{c}\text { As } \\
\text { rem }\end{array}$ & $\begin{array}{c}\text { As } \\
(\mu \mathrm{gl})\end{array}$ & $\begin{array}{c}\mathrm{Cd} \\
\mathrm{rem}\end{array}$ & $\begin{array}{c}\mathrm{Cd} \\
(\mu \mathrm{gl})\end{array}$ & $\begin{array}{c}\mathrm{Cr} \\
\mathrm{rem}\end{array}$ & $\begin{array}{c}\mathrm{Cr} \\
(\mu \mathrm{gl})\end{array}$ & $\begin{array}{c}\mathrm{Pb} \\
\text { rem }\end{array}$ & $\begin{array}{c}\mathrm{Pb} \\
(\mu \mathrm{gl})\end{array}$ & $\mathrm{pH}$ & $\begin{array}{c}\text { TDS } \\
(\mathrm{mg} / \mathrm{l})\end{array}$ \\
\hline 375828101111801 & 37.9743888889 & -101.1884444444 & 4/7/1999 11:00:00 AM & & 2.16 & $<$ & 1 & $<$ & 1 & $<$ & 1 & 7.45 & 862 \\
\hline 380331100352801 & 38.0588888889 & -100.5907500000 & 4/17/1999 9:00:00 AM & & 4.1 & $<$ & 1 & & 1 & $<$ & 1 & 7.49 & 666 \\
\hline 380331100352801 & 38.0588888889 & -100.5907500000 & 3/19/2010 11:20:00 AM & & 4.252 & & 0.0422 & & 0.8545 & & 0.0907 & 7.43 & 684.93 \\
\hline 380331100352801 & 38.0588888889 & -100.5907500000 & 4/12/2012 2:00:00 PM & & 4.174 & $<$ & 0.016 & & 0.8196 & & 0.252 & 7.23 & 668.28 \\
\hline 382947100443201 & 38.4963333333 & -100.7421666667 & 4/8/1999 11:00:00 AM & & 6.71 & $<$ & 1 & $<$ & 1 & $<$ & 1 & 7.43 & 601 \\
\hline 382947100443201 & 38.4963333333 & -100.7421666667 & 3/20/2010 2:00:00 PM & & 6.485 & & 0.3899 & & 0.485 & & 0.1083 & 7.42 & 628.99 \\
\hline 383008101315601 & 38.5022500000 & -101.5321944444 & 4/28/1999 10:00:00 AM & & 5.29 & $<$ & 1 & $<$ & 1 & $<$ & 1 & 7.78 & 269 \\
\hline 383008101315601 & 38.5022500000 & -101.5321944444 & 3/21/2010 12:00:00 PM & & 4.91 & & 0.0812 & & 1.037 & $\mathrm{E}$ & 0.0286 & 7.72 & 283.96 \\
\hline 383758101195801 & 38.6326944444 & -101.3327500000 & 5/22/1999 9:00:00 AM & & 3.45 & $<$ & 1 & $<$ & 1 & $<$ & 1 & 7.51 & 453 \\
\hline 383919101040101 & 38.6553333333 & -101.0668333333 & 4/29/1999 12:00:00 PM & & 3.6 & $<$ & 1 & & 1 & $<$ & 1 & 7.58 & 381 \\
\hline 385210100164501 & 36.8697250000 & -100.2799611111 & 6/7/1999 11:00:00 AM & & 1.21 & $<$ & 1 & & & $<$ & 1 & 7.4 & 311 \\
\hline 385904099522201 & 38.9844444444 & -99.8730277778 & 5/24/1999 10:00:00 AM & & 3.44 & $<$ & 1 & $<$ & 1 & $<$ & 1 & 7.15 & 493 \\
\hline 385904099522201 & 38.9844444444 & -99.8730277778 & 3/21/2010 6:00:00 PM & & 4.182 & & 0.0355 & & 0.1484 & & 0.1185 & 7.05 & 815.64 \\
\hline 390622101003201 & 39.1060833333 & -101.0086388889 & 5/23/1999 5:00:00 PM & & 2.62 & $<$ & 1 & & 1.2 & $<$ & 1 & 7.65 & 365 \\
\hline 390830102052001 & 39.1409722222 & -102.0888333333 & 4/30/1999 12:00:00 PM & & 4.16 & $<$ & 1 & $<$ & 1 & $<$ & 1 & 7.87 & 181 \\
\hline 390830102052001 & 39.1409722222 & -102.0888333333 & 3/22/2010 10:00:00 AM & & 2.29 & & 0.0468 & $\mathrm{E}$ & 0.0985 & & 0.0506 & 7.95 & 216.98 \\
\hline 390838100411701 & 39.1440555556 & -100.6882222222 & 5/21/1999 10:00:00 AM & & 4.12 & $<$ & 1 & & 1.1 & $<$ & 1 & 7.47 & 282 \\
\hline 391044100051001 & 39.1790277778 & -100.0861111111 & 5/25/1999 10:00:00 AM & & 5.89 & $<$ & 1 & $<$ & 1 & $<$ & 1 & 7.5 & 289 \\
\hline 391921101385501 & 39.3225833333 & -101.6486388889 & 5/20/1999 10:00:00 AM & & 2.04 & $<$ & 1 & & 1.3 & & 1.183 & 7.84 & 276 \\
\hline
\end{tabular}


Table C.3. Central High Plains public water supply well study.

\begin{tabular}{|c|c|c|c|c|c|c|c|c|c|c|c|c|c|}
\hline staid & Latitude1983 & Longitude1983 & Datetime & $\begin{array}{c}\text { As } \\
\text { rem }\end{array}$ & $\begin{array}{c}\text { As } \\
(\mu \mathrm{gl})\end{array}$ & $\begin{array}{l}\mathrm{Cd} \\
\text { rem }\end{array}$ & $\begin{array}{c}\mathrm{Cd} \\
(\mu \mathrm{gl})\end{array}$ & $\begin{array}{c}\mathrm{Cr} \\
\mathrm{rem}\end{array}$ & $\begin{array}{c}\mathrm{Cr} \\
(\mu \mathrm{gl})\end{array}$ & $\begin{array}{l}\mathrm{Pb} \\
\text { rem }\end{array}$ & $\begin{array}{c}\mathrm{Pb} \\
(\mu \mathrm{gl})\end{array}$ & $\mathrm{pH}$ & $\begin{array}{c}\text { TDS } \\
(\mathrm{mg} / \mathrm{l})\end{array}$ \\
\hline 352030101224801 & 35.3417916667 & -101.3800111111 & 7/23/1999 9:00:00 AM & & & & & & & & & 7.54 & 320 \\
\hline 352030101224801 & 35.3417916667 & -101.3800111111 & 7/23/1999 9:09:00 AM & & 1.33 & $<$ & 1 & & 3.7 & $<$ & 1 & & \\
\hline 353114100571301 & 35.5206638889 & -100.9535472222 & 7/23/1999 2:00:00 PM & & & & & & & & & 7.59 & 934 \\
\hline 353114100571301 & 35.5206638889 & -100.9535472222 & 7/23/1999 2:09:00 PM & & 1.22 & $<$ & 1 & & 2 & $<$ & 1 & & \\
\hline 354714099465201 & 35.7871111111 & -99.7810916667 & 7/24/1999 10:00:00 AM & & & & & & & & & 7.37 & 312 \\
\hline 354714099465201 & 35.7871111111 & -99.7810916667 & 7/24/1999 10:09:00 AM & & 1.79 & $<$ & 1 & $<$ & 1 & $<$ & 1 & & \\
\hline 360428102321101 & 36.0744111111 & -102.5365083333 & 7/21/1999 11:00:00 AM & & & & & & & & & 7.65 & 290 \\
\hline 360428102321101 & 36.0744111111 & -102.5365083333 & 7/21/1999 11:09:00 AM & & 2.33 & $<$ & 1 & & 1 & $<$ & 1 & & \\
\hline 361956102043201 & 36.3322805556 & -102.0756555556 & 7/20/1999 10:00:00 AM & & & & & & & & & 7.65 & 377 \\
\hline 361956102043201 & 36.3322805556 & -102.0756555556 & 7/20/1999 10:09:00 AM & $<$ & 1 & $<$ & 1 & & 3.1 & & 1.464 & & \\
\hline 362424100481401 & 36.4065305556 & -100.8039666667 & 7/25/1999 9:00:00 AM & & & & & & & & & 7.62 & 380 \\
\hline 362424100481401 & 36.4065305556 & -100.8039666667 & 7/25/1999 9:09:00 AM & & 4.9 & $<$ & 1 & & 2.6 & $<$ & 1 & & \\
\hline 364411102292601 & 36.7364972222 & -102.4906805556 & 7/19/1999 10:00:00 AM & & & & & & & & & 7.44 & 407 \\
\hline 364411102292601 & 36.7364972222 & -102.4906805556 & 7/19/1999 10:09:00 AM & & 2.27 & $<$ & 1 & & & $<$ & 1 & & \\
\hline 365937101562401 & 36.9936777778 & -101.9399416667 & 7/22/1999 11:00:00 AM & & & & & & & & & 7.37 & 456 \\
\hline 365937101562401 & 36.9936777778 & -101.9399416667 & 7/22/1999 11:09:00 AM & $<$ & 1 & $<$ & 1 & $<$ & 1 & $<$ & 1 & & \\
\hline 370308100544801 & 37.0521916667 & -100.9133361111 & 7/25/1999 2:00:00 PM & & & & & & & & & 7.77 & 336 \\
\hline 370308100544801 & 37.0521916667 & -100.9133361111 & 7/25/1999 2:09:00 PM & $<$ & 1 & $<$ & 1 & $<$ & 1 & $<$ & 1 & & \\
\hline 373409101233501 & 37.5692944444 & -101.3931111111 & 7/26/1999 11:00:00 AM & & & & & & & & & 7.53 & 514 \\
\hline 373409101233501 & 37.5692944444 & -101.3931111111 & 7/26/1999 11:09:00 AM & & 2.35 & $<$ & 1 & & 7.9 & $<$ & 1 & & \\
\hline 373529100284501 & 37.5913083333 & -100.4792638889 & 7/27/1999 1:00:00 PM & & & & & & & & & 7.42 & 309 \\
\hline 373529100284501 & 37.5913083333 & -100.4792638889 & 7/27/1999 1:09:00 PM & & 1.07 & $<$ & 1 & & 1.3 & $<$ & 1 & & \\
\hline 374902100203501 & 37.8173611111 & -100.3430805556 & 7/27/1999 9:00:00 AM & & & & & & & & & 7.48 & 352 \\
\hline 374902100203501 & 37.8173611111 & -100.3430805556 & 7/27/1999 9:09:00 AM & & 1.2 & $<$ & 1 & & 1.4 & $<$ & 1 & & \\
\hline 375417100531901 & 37.9046388889 & -100.8886972222 & 7/28/1999 11:00:00 AM & & & & & & & & & 7.66 & 248 \\
\hline 375417100531901 & 37.9046388889 & -100.8886972222 & 7/28/1999 11:09:00 AM & & 1.59 & $<$ & 1 & & 1.2 & $<$ & 1 & & \\
\hline
\end{tabular}


Table C.4. Central High Plains reconnaissance study.

\begin{tabular}{|c|c|c|c|c|c|c|c|c|c|c|c|c|c|}
\hline staid & Latitude1983 & Longitude 1983 & Datetime & $\begin{array}{c}\text { As } \\
\text { rem }\end{array}$ & $\begin{array}{c}\text { As } \\
(\mu \mathrm{gl})\end{array}$ & $\begin{array}{c}\mathrm{Cd} \\
\mathrm{rem}\end{array}$ & $\begin{array}{c}\mathrm{Cd} \\
(\mu \mathrm{gl})\end{array}$ & $\begin{array}{l}\mathrm{Cr} \\
\mathrm{rem}\end{array}$ & $\begin{array}{c}\mathrm{Cr} \\
(\mu \mathrm{gl})\end{array}$ & $\begin{array}{l}\mathrm{Pb} \\
\text { rem }\end{array}$ & $\begin{array}{c}\mathrm{Pb} \\
(\mu \mathrm{gl})\end{array}$ & $\mathrm{pH}$ & $\begin{array}{c}\mathrm{TDS} \\
(\mathrm{mg} / \mathrm{l})\end{array}$ \\
\hline 363817101213101 & 36.6382500000 & -101.3588333333 & 2/17/1999 11:00:00 AM & & & & & & & & & 7.73 & 390 \\
\hline 365610101484301 & 36.9361944444 & -101.8121944444 & 2/5/1999 1:00:00 PM & & & & & & & & & 7.69 & 379 \\
\hline 374220100422501 & 37.7055833333 & -100.7069722222 & 2/4/1999 11:00:00 AM & & & & & & & & & 7.19 & 642 \\
\hline 374220100422501 & 37.7055833333 & -100.7069722222 & 6/28/2000 11:00:00 AM & & & & & & & & & 6.93 & 554 \\
\hline 375734100452301 & 37.9595833333 & -100.7564166667 & 2/2/1999 11:30:00 AM & & & & & & & & & 7 & 1058 \\
\hline 375855100484001 & 37.9820833333 & -100.8110000000 & 2/3/1999 11:00:00 AM & & & & & & & & & 6.96 & 4916 \\
\hline 375855100484001 & 37.9820833333 & -100.8110000000 & 6/27/2000 12:00:00 PM & & & & & & & & & 6.81 & 4512 \\
\hline
\end{tabular}


Table C.5. Central High Plains transect study.

\begin{tabular}{|c|c|c|c|c|c|c|c|c|c|c|c|c|c|}
\hline staid & Latitude 1983 & Longitude 1983 & Datetime & $\begin{array}{c}\text { As } \\
\text { rem }\end{array}$ & $\begin{array}{c}\text { As } \\
(\mu \mathrm{gl})\end{array}$ & $\begin{array}{c}\mathrm{Cd} \\
\text { rem }\end{array}$ & $\begin{array}{c}\mathrm{Cd} \\
(\mu \mathrm{gl})\end{array}$ & $\begin{array}{c}\mathrm{Cr} \\
\text { rem }\end{array}$ & $\begin{array}{c}\mathrm{Cr} \\
(\mu \mathrm{gl})\end{array}$ & $\begin{array}{c}\mathrm{Pb} \\
\text { rem }\end{array}$ & $\begin{array}{c}\mathrm{Pb} \\
(\mu \mathrm{gl})\end{array}$ & $\mathrm{pH}$ & $\begin{array}{c}\text { TDS } \\
(\mathrm{mg} / \mathrm{l})\end{array}$ \\
\hline 370033100534201 & 37.0091861111 & -100.8952583333 & 8/26/1999 10:00:00 AM & & & & & & & & & 7.47 & 364 \\
\hline 370033100534201 & 37.0091861111 & -100.8952583333 & 8/26/1999 10:09:00 AM & & 2.61 & $<$ & 1 & & 1.8 & $<$ & 1 & & \\
\hline 370033100534202 & 37.0091861111 & -100.8952583333 & 8/26/1999 2:00:00 PM & & & & & & & & & 7.59 & 309 \\
\hline 370033100534202 & 37.0091861111 & -100.8952583333 & 8/26/1999 2:09:00 PM & & 3.6 & $<$ & 1 & & 3.6 & $<$ & 1 & & \\
\hline 370033100534203 & 37.0091861111 & -100.8952583333 & 8/27/1999 10:00:00 AM & & & & & & & & & 7.72 & 311 \\
\hline 370033100534203 & 37.0091861111 & -100.8952583333 & 8/27/1999 10:09:00 AM & & 1.67 & $<$ & 1 & & 3.2 & $<$ & 1 & & \\
\hline 370033100534204 & 37.0091861111 & -100.8952583333 & 8/27/1999 2:00:00 PM & & & & & & & & & 7.65 & 331 \\
\hline 370033100534204 & 37.0091861111 & -100.8952583333 & 8/27/1999 2:09:00 PM & & 4.55 & $<$ & 1 & & 2.6 & $<$ & 1 & & \\
\hline 370033100534204 & 37.0091861111 & -100.8952583333 & 9/13/2000 9:00:00 AM & & & & & & & & & 7.39 & 328 \\
\hline 370130101180901 & 37.0250166667 & -101.3026111111 & 8/28/1999 10:00:00 AM & & & & & & & & & 7.64 & 381 \\
\hline 370130101180901 & 37.0250166667 & -101.3026111111 & 8/28/1999 10:09:00 AM & & 1.57 & $<$ & 1 & & 1.9 & $<$ & 1 & & \\
\hline 370130101180902 & 37.0250166667 & -101.3026111111 & 8/28/1999 2:00:00 PM & & & & & & & & & 7.66 & 366 \\
\hline 370130101180902 & 37.0250166667 & -101.3026111111 & 8/28/1999 2:09:00 PM & & 1.73 & $<$ & 1 & & 2.4 & $<$ & 1 & & \\
\hline 370130101180903 & 37.0250166667 & -101.3026111111 & 8/29/1999 2:00:00 PM & & & & & & & & & 7.5 & 397 \\
\hline 370130101180903 & 37.0250166667 & -101.3026111111 & 8/29/1999 2:09:00 PM & & 2.01 & $<$ & 1 & & 2.3 & $<$ & 1 & & \\
\hline 370130101180904 & 37.0250166667 & -101.3026111111 & 8/29/1999 10:00:00 AM & & & & & & & & & 7.65 & 372 \\
\hline 370130101180904 & 37.0250166667 & -101.3026111111 & 8/29/1999 10:09:00 AM & & 3.67 & $<$ & 1 & & 2.2 & $<$ & 1 & & \\
\hline 370130101180904 & 37.0250166667 & -101.3026111111 & 9/14/2000 8:00:00 AM & & & & & & & & & 7.79 & 388 \\
\hline 370402101394401 & 37.0673527778 & -101.6624222222 & 8/30/1999 2:00:00 PM & & & & & & & & & 7.47 & 862 \\
\hline 370402101394401 & 37.0673527778 & -101.6624222222 & 8/30/1999 2:09:00 PM & & 1.81 & $<$ & 1 & & 1.8 & $<$ & 1 & & \\
\hline 370402101394402 & 37.0673527778 & -101.6624222222 & 8/30/1999 10:00:00 AM & & & & & & & & & 7.7 & 290 \\
\hline 370402101394402 & 37.0673527778 & -101.6624222222 & 8/30/1999 10:09:00 AM & & 2.27 & $<$ & 1 & $<$ & 1 & $<$ & 1 & & \\
\hline 370434100405201 & 37.0761361111 & -100.6811305556 & 8/31/1999 2:00:00 PM & & & & & & & & & 7.15 & 15430 \\
\hline 370434100405201 & 37.0761361111 & -100.6811305556 & 8/31/1999 2:09:00 PM & & 12.08 & $<$ & 10 & $<$ & 1 & $<$ & 10 & & \\
\hline 370434100405201 & 37.0761361111 & -100.6811305556 & 10/18/2000 2:00:00 PM & & 9.41 & $<$ & 0.37 & & 8.34 & $<$ & 0.8 & 7.3 & 15430 \\
\hline 370434100405202 & 37.0761361111 & -100.6811305556 & 9/1/1999 2:00:00 PM & & & & & & & & & 7.13 & 404 \\
\hline 370434100405202 & 37.0761361111 & -100.6811305556 & 9/1/1999 2:09:00 PM & $<$ & 1 & $<$ & 3 & $<$ & 1 & $<$ & 3 & & \\
\hline 370434100405203 & 37.0761361111 & -100.6811305556 & 8/31/1999 10:00:00 AM & & & & & & & & & 7.5 & 414 \\
\hline 370434100405203 & 37.0761361111 & -100.6811305556 & 8/31/1999 10:09:00 AM & & 1.03 & $<$ & 1 & & 1.9 & $<$ & 1 & & \\
\hline 370434100405204 & 37.0761361111 & -100.6811305556 & 9/1/1999 10:00:00 AM & & & & & & & & & 7.59 & 370 \\
\hline 370434100405204 & 37.0761361111 & -100.6811305556 & 9/1/1999 10:09:00 AM & $<$ & 1 & $<$ & 1 & & 1 & $<$ & 1 & & \\
\hline
\end{tabular}


Table C.6. Central High Plains unsaturated zone study.

\begin{tabular}{|c|c|c|c|c|c|c|c|c|c|c|c|c|c|}
\hline staid & Latitude 1983 & Longitude 1983 & Datetime & $\begin{array}{l}\text { As } \\
\text { rem }\end{array}$ & $\begin{array}{c}\text { As } \\
(\mu \mathrm{gl})\end{array}$ & $\begin{array}{c}\mathrm{Cd} \\
\text { rem }\end{array}$ & $\begin{array}{c}\mathrm{Cd} \\
(\mu \mathrm{gl})\end{array}$ & $\begin{array}{c}\mathrm{Cr} \\
\text { rem }\end{array}$ & $\begin{array}{c}\mathrm{Cr} \\
(\mu \mathrm{gl})\end{array}$ & $\begin{array}{c}\mathrm{Pb} \\
\text { rem }\end{array}$ & $\begin{array}{c}\mathrm{Pb} \\
(\mu \mathrm{gl})\end{array}$ & $\mathrm{pH}$ & $\begin{array}{c}\mathrm{TDS} \\
(\mathrm{mg} / \mathrm{l})\end{array}$ \\
\hline 370349101431001 & 37.0635000000 & -101.7193333333 & 7/25/2000 12:00:00 PM & & & & & & & & & 7.5 & 336 \\
\hline 370349101431001 & 37.0635000000 & -101.7193333333 & 11/29/2000 3:00:00 PM & & & & & & & & & & \\
\hline 370349101431001 & 37.0635000000 & -101.7193333333 & 8/16/2001 12:00:00 PM & & & & & & & & & 7.7 & \\
\hline 374412100453201 & 37.7367777778 & -100.7588333333 & 7/10/2000 11:00:00 AM & & & & & & & & & 7.43 & 675 \\
\hline 374412100453201 & 37.7367777778 & -100.7588333333 & 11/27/2000 6:00:00 PM & & & & & & & & & & \\
\hline 374412100453201 & 37.7367777778 & -100.7588333333 & 8/15/2001 11:00:00 AM & & & & & & & & & 7.68 & \\
\hline 374625100490701 & 37.7735555556 & -100.8186944444 & 6/29/2000 11:00:00 AM & & & & & & & & & 6.91 & 680 \\
\hline 374625100490701 & 37.7735555556 & -100.8186944444 & 8/14/2001 10:00:00 AM & & & & & & & & & 7.31 & \\
\hline
\end{tabular}






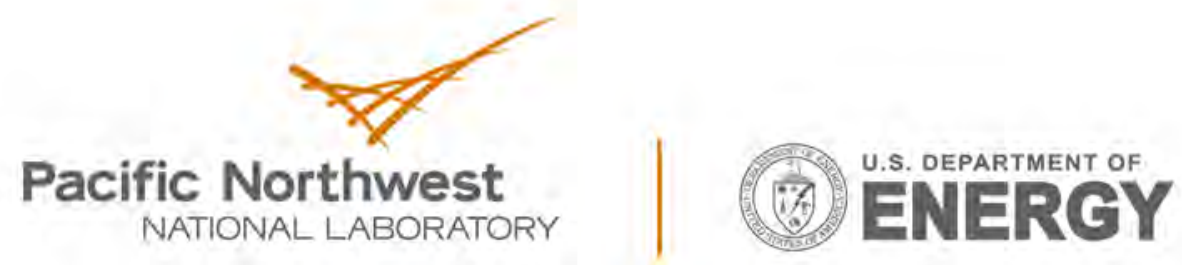

Proudly Operated by Battelle Since 1965

902 Battelle Boulevard

P.O. Box 999

Richland, WA 99352

1-888-375-PNNL (7665)

www.pnnl.gov 